FACULDADE DE ZOOTECNIA E ENGENHARIA DE ALIMENTOS

\author{
MARCELO CANDIDO
}

Aspectos celulares e moleculares da ranavirose experimental em tilápias do Nilo (Oreochromis niloticus)

Pirassununga 


\title{
MARCELO CANDIDO
}

\section{Aspectos celulares e moleculares da ranavirose experimental em tilápias do Nilo (Oreochromis niloticus)}

\author{
Versão corrigida
}

Tese apresentada à Faculdade de Zootecnia e Engenharia de Alimentos da Universidade de São Paulo, como parte dos requisitos para obtenção do título de Doutor em Ciências do Programa de Pós-graduação em Zootecnia.

Área de Concentração: Qualidade e Produtividade Animal

Orientador: Prof. Dr. Ricardo Luiz Moro de Sousa

\section{Pirassununga}


Ficha catalográfica elaborada pelo Serviço de Biblioteca e Informação, FZEA/USP, com os dados fornecidos pelo(a) autor(a)

Candido, Marcelo

Aspectos celulares e moleculares da ranavirose

$\mathrm{C} 217 \mathrm{a}$ experimental em tilápias do Nilo (Oreochromis niloticus) / Marcelo Candido ; orientador Ricardo Luiz Moro de Sousa. - - Pirassununga, 2018. $127 \mathrm{f}$.

Tese (Doutorado - Programa de Pós-Graduação em Zootecnia) - - Faculdade de Zootecnia e Engenharia de Alimentos, Universidade de São Paulo.

1. Iridovirus. 2. Doenças infecciosas em animais. 3. Genomas. 4. Epidemiologia veterinária. 5. Tilápia-do-Nilo. I. de Sousa, Ricardo Luiz Moro, orient. II. Título. 


\section{Aspectos celulares e moleculares da ranavirose experimental em tilápias do Nilo (Oreochromis niloticus)}

Tese apresentada à Faculdade de Zootecnia e Engenharia de Alimentos da Universidade de São Paulo, como parte dos requisitos para obtenção do título de Doutor em Ciências do Programa de Pós-graduação em Zootecnia.

Área de Concentração: Qualidade e Produtividade Animal

Data de aprovação: 10/12/2018

Banca examinadora:

Prof. Dr. Ricardo Luiz Moro de Sousa

Instituição: Faculdade de Zootecnia e Engenharia de Alimentos - FZEA/USP

Presidente da banca examinadora

Prof. Dr. Adriano de Oliveira Torres Carrasco

Instituição: Universidade Estadual do Centro-Oeste do Paraná - UNICENTRO

Dra $^{\mathrm{a}}$. Cláudia Maris Ferreira Mostério

Instituição: Agência Paulista de Tecnologia dos Agronegócios - APTA

Prof. Dr. Fabio Carvalho Dias

Instituição: Instituto Federal de Educação, Ciência e Tecnologia do Sul de Minas Gerais, Campus Muzambinho

Prof. Dr. Hélio José Montassier

Instituição: Faculdade de Ciências Agrárias e Veterinárias - FCAV/UNESP

Prof. Dr. Luiz Tadeu Moraes Figueiredo

Instituição: Faculdade de Medicina de Ribeirão Preto - FMRP/USP 
Aos meus pais, por todo amor e dedicação! 


\section{AGRADECIMENTOS}

Primeiramente a Deus, pela conquista, força e dedicação na trajetória.

Ao Prof. Dr. Ricardo Luiz Moro de Sousa, pela oportunidade, orientação, confiança, amizade, paciência e exemplo profissional. Será sempre meu maior Professor!

A minha noiva Rafaela Torrezan Privatti, pela companhia e ajuda nos cuidados dos animais, inclusive aos finais de semana e feriados, e também pelo apoio nos momentos difíceis.

Ao Prof. Dr. Antonio Augusto Mendes Maia, pelo apoio junto ao projeto, confiança, amizade e exemplo profissional.

Ao Mateus Maldonado Carriero, pela ajuda na realização da PCR quantitativa em tempo real e pela amizade.

Ao Jose Luis Privatti, meu sogro, pela ajuda no transporte dos animais e dos tanques, e pela amizade de sempre.

Aos meus pais Celso Candido e Vera Lucia Vitoreli Candido, pelo apoio e carinho.

Ao meu irmão Wilson Candido, pelo apoio e carinho.

A Dra. Sabrina Ribeiro de Almeida Queiroz, pelo conhecimento transmitido e amizade de longa data.

A Dra. Cláudia Maris Ferreira Mostério, pela parceria na realização do sequenciamento completo e pela amizade.

Ao financiamento fornecido pela FAPESP, o qual possibilitou minha dedicação exclusiva a pesquisa, a escrita desta tese e artigos - Processo número 2017/01718-3.

Ao César Polettini, sócio proprietário da Piscicultura Polettini, pelo fornecimento dos animais sem custo algum, há tempos apoiando a pesquisa cientifica.

Ao pessoal do CEPTA, pelo empréstimo dos tanques e apoio junto a pesquisa.

A Danielle Passarelli, pela ajuda nos exames sanguíneos e pela amizade.

A Dra. María J. Forzán da Universidade de Cornell, pela parceria junto as análises imunohistoquímicas e de hibridização in situ, pela disponibilidade de orientação e amizade.

Ao Johnny Maciel de Souza, pela valiosa ajuda junto as análises estatísticas e amizade.

Aos amigos do Instituto Biológico, Dra. Ana Maria Cristina Rebello Pinto da Fonseca Martins e Dr. Marcio Hipolito, pelo apoio na realização dos exames histopatológicos.

Aos amigos da Unicamp, Joice Ruggeri e Mariana R. Pontes, pelas prosas junto aos longos dias de qPCR.

A Pamela Rodrigues, que tive o prazer de orientar em sua primeira iniciação científica, junto a este projeto, meu muito obrigado pela oportunidade e pela sua amizade. 
A técnica Silvia Helena Seraphin de Godoy, por toda ajuda e amizade durante todos esses anos.

Aos amigos que já passaram e aos que ainda permanecem no Laboratório de Higiene Zootécnica.

Aos demais professores e funcionários da Faculdade de Zootecnia e Engenharia de Alimentos da Universidade de São Paulo, pelos conselhos e contribuições.

O presente trabalho foi realizado com apoio da Coordenação de Aperfeiçoamento de Pessoal de Nível Superior - Brasil (CAPES) - Código de Financiamento 001 
"Não violarei a minha aliança nem modificarei as promessas dos meus lábios." Salmo 89:34

"E foi assim que, depois de esperar pacientemente, Abraão alcançou a promessa." Hebreus 6:15 


\section{RESUMO}

CANDIDO, M. Aspectos celulares e moleculares da ranavirose experimental em tilápias do Nilo (Oreochromis niloticus). 2018. 127 f. Tese (Doutorado) - Faculdade de Zootecnia e Engenharia de Alimentos, Universidade de São Paulo, Pirassununga, 2018.

Algumas doenças associadas à piscicultura de tilápias trazem enormes prejuízos aos criadores, resultando em expressivos coeficientes de morbidade e mortalidade entre animais de todas as idades. Nesse sentido, exigências para o aprimoramento do diagnóstico laboratorial de doenças de natureza infecto-contagiosa tornaram-se constantes, face às perdas vinculadas. Os Ranavirus são vírus que infectam vertebrados ectotérmicos causando necrose generalizada, hemorragias focais e apoptose celular nos animais infectados. O presente estudo objetivou a realização de infecções experimentais em larvas e alevinos de tilápia do Nilo (Oreochromis niloticus), através de 3 diferentes modelos de infecção, utilizando estirpe de Ranavirus Frog virus 3-like; recentemente detectada e isolada no Brasil, para avaliação das patologias associadas, incluindo o sequenciamento e análise do genoma da cepa viral. Vários sinais clínicos macroscópicos e microscópicos foram observados, hemólise, hemácias com anisocitose e policromasia, alterações relacionadas a média dos volumes das hemácias e hemoglobina, índices hepato-somáticos e espleno-somáticos com interações estatisticamente significantes, linfócitos reativos, alterações nos níveis das enzimas alanina aminotransferase e corpúsculos de inclusão basofílicos em diferentes tecidos dos animais experimentados com Ranavirus FV3-like foram observados dentro do período de 60 dias pós-infecção. Além disso, animais experimentalmente infectados foram positivos ao Ranavirus através de qPCR. $\mathrm{O}$ genoma de cepa brasileira de Ranavirus FV3-like apresentou 105 kilobases, contendo 54,98\% de guanina + citosina, sendo 94 potenciais ORFs anotadas. A reconstrução filogenética, baseada em sequencias nucleotídicas, agrupou a amostra brasileira de Ranavirus no clado dos Frog virus 3-like e as maiores identidades do genoma se deram com cepas norte-americanas de FV3-like. Doze potenciais eventos de recombinação, estatisticamente significantes ( $p<$ 0,05), foram identificados entre a cepa brasileira e amostras de referência de Ranavirus FV3like. Nesse sentido, o presente trabalho contribui para o melhor entendimento da infecção causada por estirpe brasileira de Ranavirus FV3-like em tilápias do Nilo (Oreochromis niloticus). Além disso, adiciona e reforça a potencial recombinação entre diferentes estirpes de Ranavirus, colaborando para uma melhor compreensão das características de agentes virais associados a graves surtos em vertebrados ectotérmicos no país.

Palavras-chave: Ranavirus. Doenças infecciosas de peixes. Frog virus 3. 


\begin{abstract}
CANDIDO, M. Cellular and molecular aspects of the experimental ranavirus infection in Nile tilapias (Oreochromis niloticus). 2018. 127 f. Thesis (PhD) - Faculdade de Zootecnia e Engenharia de Alimentos, Universidade de São Paulo, Pirassununga, 2018.

Some diseases associated with tilapia fish farming cause enormous losses to breeders, resulting in significant morbidity and mortality rates among animals of all ages. In this sense, requirements for the improvement of the laboratory diagnosis of diseases of infectiouscontagious nature, became constant, in view of the related losses. Ranaviruses are viruses that infect ectothermal vertebrates causing widespread necrosis, focal haemorrhages and cell apoptosis in infected animals. The present study aimed to perform experimental infections in Nile tilapia (Oreochromis niloticus) fry and larvae through 3 different infection models, using Ranavirus Frog virus 3-like strain recently detected and isolated in Brazil, to evaluate the associated pathologies, including sequencing and genome analysis of the viral strain. Several macroscopic and microscopic clinical signs were observed, hemolysis, red blood cells presenting anisocytosis and polychromasia, alterations related to the mean red blood cell volumes and hemoglobin present in the red blood cells, hepato-somatic and spleno-somatic indexes showing statistically significant interactions, reactive lymphocytes, alterations in the levels of the enzymes alanine aminotransferase and basophilic inclusion corpuscles in different tissues of animals tested with Ranavirus FV3-like were observed within the 60-day post-infection period. In addition, experimentally infected animals were positive to Ranavirus through qPCR. The genome of the Ranavirus FV3-like Brazilian strain presented 105 kilobases, containing $54.98 \%$ of guanine + cytosine, with 94 potential ORFs annotated. The phylogenetic reconstruction, based on nucleotide sequences, grouped the Brazilian sample of Ranavirus in the clade of Frog virus 3-like, the greater identities of the genome were with North American strains of FV3-like. Twelve potential recombination events, statistically significant $(p<0.05)$, were identified between the Brazilian strain and reference samples of Ranavirus FV3-like. The present work contributes to a better understanding of the infection caused by the Brazilian strain of Ranavirus FV3-like in Nile tilapia (Oreochromis niloticus). In addition, it adds and reinforces the potential recombination between different strains of Ranavirus, contributing to a better understanding of the characteristics of viral agents associated with severe outbreaks in ectothermic vertebrates.
\end{abstract}

Keywords: Ranavirus. Infectious diseases of fish. Frog virus 3. 


\section{LISTA DE IMAGENS}

Imagem 1 - Fluxograma de atividades desenvolvidas na presente tese de doutorado.

Imagem 2 - Micrografia eletrônica de transmissão de cultivo de células BF-2 infectadas com cepa de Ranavirus (Frog virus 3-like) utilizada nos processos de infecção experimental........37

Imagem 3 - A. Comprimento médio do Gene MCP de Ranavirus. B. Construção de padrão para utilização em qPCR, a partir de amplificação de fragmento de 495pb do gene MCP de Ranavirus.

Imagem 4 - Região alvo de 54pb para construção de curva padrão, rastreamento e quantificação de Ranavirus através de qPCR absoluto.

Imagem 5 - Infecção experimental com Ranavirus em tilápias do Nilo, através de injeção intraperitoneal de $0,1 \mathrm{~mL}$

Imagem 6 - Animal com o globo ocular colapsado e com edema (possível hemorragia), 12 dias pós-infecção, na concentração de $10^{3}$ TCID $50 / \mathrm{mL}$

Imagem 7 - Manchas brancas e palidez no fígado dos animais, a partir de 38 dias pósinfecção, em todas as concentrações virais utilizadas, indicando possível necrose hepática...59

Imagem 8 - Eritema na região submandibular, pigmentação escura e estrias avermelhadas na superfície dos peixes, a partir de 25 dias pós-infecção, nas concentrações virais de $10^{2}, 10^{3}$ e $10^{4} \mathrm{TCID}_{50} / \mathrm{mL}$.

Imagem 9 - Diferentes graus de exoftalmia, a partir de 25 dias pós-infecção, em todas as concentrações virais utilizadas.

Imagem 10 - Bílis amarelada em $1 / 4$ dos peixes infectados, nas concentrações de $10^{3}$ e $10^{4}$

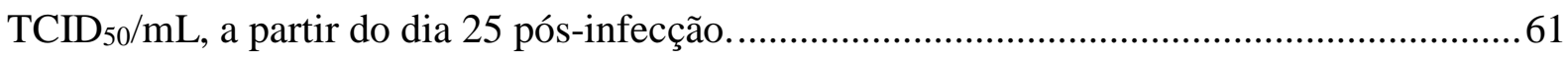

Imagem 11 - Eritrócitos maduros e trombócitos (setas). Lente objetiva de 100X.................62

Imagem 12 - Trombócitos agregados (seta). Lente objetiva de 10X....................................62

Imagem 13 - Anisocitose e policromasia. Lente objetiva de 100X.....................................63

Imagem 14 - Linfócitos (setas). Lente objetiva de 100X.....................................................63

Imagem 15 - Linfócitos reativos (setas). Lente objetiva de 100X........................................64

Imagem 16 - Monócitos (setas). Lente objetiva de 100X.....................................................64

Imagem 17 - Neutrófilos (setas). Lente objetiva de 100X..................................................64

Imagem 18 - Eosinófilos (setas). Lente objetiva de 100X..................................................65

Imagem 19 - Basófilo (seta). Lente objetiva de 100X.......................................................65 
Imagem 20 - Células degeneradas (setas). Lente objetiva de 100X (superior) e 10X (inferior).

Imagem 21 - Fotografia de gel de agarose corado com SYBR ${ }^{\circledR}$ Gold, sob luz UV, ilustrando resultado de amplificação de amostras de DNA extraído de tecidos de larvas e de alevinos de tilápia utilizados no presente projeto, incluindo controle negativo (água DEPC) mais fragmento amplificado de controle positivo, referente a $321 \mathrm{pb}$ do gene MCP do genoma de Ranavirus. .68

Imagem 22 - Curva de amplificação em qPCR para cálculo de eficiência de primer a 400nM.

Imagem 23 - Curva de amplificação em PCR quantitativo absoluto para Ranavirus, a partir de diluições seriadas de DNA purificado $\left(10^{-1}\right.$ a $\left.10^{-6}\right)$.

Imagem 24 - Curva padrão para qPCR a partir de diluições seriadas de base 10 de fragmento amplificado do gene MCP de Ranavirus, realizada com o sistema TaqMan. . .70

Imagem 25 - Resultado de PCR quantitativo absoluto em tempo real, a partir de amostras de alevinos de tilápia do Nilo infectados experimentalmente com Ranavirus FV3-like, através de injeção intraperitoneal e coabitação.

Imagem 26 - Resultado de PCR quantitativo absoluto em tempo real, a partir de pool de tecidos de larvas de tilápia do Nilo infectadas experimentalmente com Ranavirus.

Imagem 27 - Repetição da amostra de larva de tilápia infectada experimentalmente com Ranavirus na concentração de $10^{3} \mathrm{TCID}_{50} / \mathrm{mL}$, dia 11 pós-infecção, com Ct ajustado para 0,168 (mesmo valor da curva padrão).

Imagem 28 - Histopatologia em larvas de tilápia do Nilo infectadas experimentalmente com estirpe brasileira de Ranavirus FV3-like. Nas ilustrações (A, B e C), indicado por setas brancas, observam-se estruturas sugestivas de corpúsculos de inclusão basofílicos em tecidos renais dos animais analisados.

Imagem 29 - Resultado histopatológico em tecidos cardíacos de larvas de tilápia do Nilo infectadas experimentalmente com estirpe brasileira de Ranavirus FV3-like, nas concentrações de $10^{3}$ (fotomicrografia A) e $10^{2}$ (fotomicrografia B) TCID $50 / \mathrm{mL}$, dia 60 pósinfecção.

Imagem 30 - Resultado histopatológico em tecidos hepáticos de larvas de tilápia do Nilo infectadas experimentalmente com estirpe brasileira de Ranavirus FV3-like na concentração de $10^{3} \mathrm{TCID}_{50} / \mathrm{mL}$, dia 60 pós-infecção.

Imagem 31 - Resultado histopatológico em tecido cardíaco de larva de tilápia do Nilo infectada experimentalmente com estirpe brasileira de Ranavirus FV3-like na concentração de $10^{3} \mathrm{TCID}_{50} / \mathrm{mL}$, dia 60 pós-infecção. 
Imagem 32 - Larva de tilápia infectada experimentalmente com Ranavirus na concentração de $10^{4} \mathrm{TCID}_{50} / \mathrm{mL}$, dia 10 pós infecção, corada com hematoxilina e eosina (H\&E) no topo e imuno-histoquímica (IHC) na parte inferior, utilizando anticorpo de Ranavirus (anti-EHNV).

Imagem 33 - Corte tecidual em larva de tilápia infectada experimentalmente com Ranavirus FV3-like na concentração de $10^{4} \mathrm{TCID}_{50} / \mathrm{mL}$, dia 10 pós infecção, submetido à coloração com ISH.

Imagem 34 - Reconstrução filogenética utilizando genomas de todas as diferentes espécies de Ranavirus disponíveis no GenBank.

Imagem 35 - Identidade de sequências nucleotídicas do gene MCP entre diferentes espécies de Ranavirus. As setas em preto indicam a amostra obtida e analisada neste estudo. 81

Imagem 36 - Eventos de recombinação entre a amostra analisada e amostras de referência de Ranavirus FV3-like (continua)..

Imagem 37 - Lesões macroscópicas observadas em peixes com doença ranaviral. 90

Imagem 38 - Alterações histopatológicas observadas em animais com doença ranaviral em infecções experimentais com Ranavirus FV3-like.

Imagem 39 - Histopatologia em rã da espécie Lithobates catesbeianus infectada com Ranavirus. 


\section{LISTA DE QUADROS}

Quadro 1 - Reagentes utilizados para amplificação de fragmento do gene MCP de Ranavirus

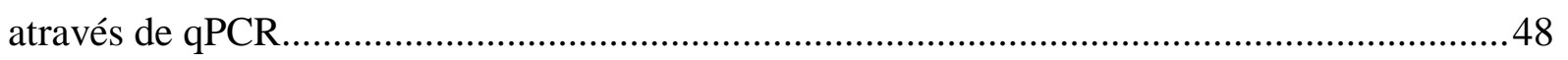




\section{LISTA DE TABELAS}

Tabela 1 - Solução de Natt e Herrick para contagem de eritrócitos e leucócitos utilizada na presente investigação.

Tabela 2 - Oligonucleotídeos iniciadores utilizados para construção de padrão para qPCR absoluto

Tabela 3 - Oligonucleotídeos iniciadores e probe utilizados no qPCR absoluto para Ranavirus.

Tabela 4 - Concentrações de DNA e de primers utilizados para padronização das reações de qPCR.

Tabela 5 - Sequências genômicas de Ranavirus utilizadas para reconstrução filogenética, análises de identidade e detecção de recombinação com indicação da espécie viral, hospedeiro, origem e respectivos códigos de acesso no GenBank.

Tabela 6 - Diluição seriada para construção da curva padrão em qPCR com valores médios de Ct e cópias de DNA.

Tabela 7 - Identidade de sequências nucleotídicas (\%) entre genomas de Ranavirus de diferentes espécies.

Tabela 8 - Resultados de eritrograma e proteína plasmática total (continua)..... 110

Tabela 9 - Resultados de leucograma (continua).

Tabela 10 - Resultados de bioquímica plasmática (continua).

Tabela 11 - Resultados de índices somáticos (continua). 116

Tabela 12 - Resultados para análise estatística com alanina aminotransferase.

Tabela 13 - Resultados para análise estatística com aspartato aminotransferase.

Tabela 14 - Resultados para análise estatística com leucograma (leucócitos, neutrófilos, linfócitos e monócitos).

Tabela 15 - Resultados para análise estatística com leucograma (eosinófilos e basófilos)...122

Tabela 16 - Resultados para análise estatística com eritrograma (continua). 123

Tabela 17 - Resultados para análise estatística com índices somáticos (continua). 125 


\section{LISTA DE ABREVIATURAS E SIGLAS}

Água DEPC - Água tratada com o reagente Diethyl Pyrocarbonate ALT - Alanina aminotransferase

AST - Aspartato aminotransferase

ATV - Ambystoma tigrinum virus

BCIP - 5-bromocresyl-3-indolyl-phosphate

BF-2 - Bluegill fry ATCC ${ }^{\circledR}$ CCL-91 ${ }^{\mathrm{TM}}$

BIV - Bohle iridovirus

C - Citosina

CHCM - Concentração de hemoglobina corpuscular média

Cm - Centímetro

CMTV - Common midwife toad virus

CPE - Efeito citopático

dL - Decilitro

DNA - Ácido desoxirribonucleico

dsDNA - Double stranded DNA viruses

ECV - European catfish virus

EDTA - Ácido etilenodiamino tetra-acético

EHNV - Epizootic haematopoietic necrosis virus

EUA - Estados Unidos da América

fL - Fentolitros

FV3 - Frog virus 3

g - Grama

G - Guanina

$g$ - Unidade de aceleração definida como exatamente 9,806 $65 \mathrm{~m} / \mathrm{s}^{2}$

GenBank - Banco de dados de Nucleotídeos do NLM/NCBI

H\&E - Hematoxilina e eosina

HCL - Ácido clorídrico

HCM - Hemoglobina corpuscular média

IES - Índice espleno-somático

IHC - Imuno-histoquímica

IHS - Índice hepato-somático

ISH - Hibridização in situ 
kb - Kilobase

Kg - Quilograma

L - Litro

LMBV - Largemouth bass virus

M - Molar

MCP - Major Capsid Protein

mg - Miligrama

min - Minuto

mL - Mililitro

mM - Milimolar

$\mathrm{N}$ - Normal

$\mathrm{NaCl}$ - Cloreto de sódio

NBT - Nitro-blue tetrazolium

Ndn - Nada digno de nota

ng - Nanograma

NGS - Next generation sequencing

NJ - Neighbor-Joining

nm - Nanômetro

nM - Nanomolar

Obs - Observação

ORF - Open reading frame

p - Probabilidade de significância

$\mathrm{p} / \mathrm{v}$ - Peso/volume

$\mathrm{pb}$ - Par de base

PBS - Tampão fosfato-salino

PCR - Reação em cadeia da polimerase

PFU - Plaque-forming units

pg - Picograma

$\mathrm{pH}$ - Potencial hidrogeniônico

PPT - Proteína plasmática total

q.s.p. - Quantidade suficiente para

qPCR - Reação em cadeia da polimerase quantitativa em tempo real

Ref. - Referência

RPM - Rotação por minuto 
SDT - Sequence Demarcation Tool

SEM - Erro padrão da média

SGIV - Singapore grouper iridovirus

SM - Meio padrão

SP - São Paulo

SSC - Citrato de sódio salino

TA - Temperatura ambiente

TAE - Tris-Acetato/EDTA

TCID 50 - 50\% Tissue Culture Infective Dose

Tris-HCl - Tris Hidrocloreto

UV - Ultravioleta

VCM - Volume corpuscular médio

VHSV - Vírus da septicemia hemorrágica viral

w/v - Weight/volume

$\mu \mathrm{g}$ - Micrograma

$\mu \mathrm{L}$ - Microlitro

$\mu \mathrm{m}$ - Micrometro

$\mu \mathrm{M}$ - Micromolar

Observação: dado o fato de algumas abreviaturas e siglas terem sido consagradas na literatura especializada, seguem sua grafia no idioma inglês. 


\section{LISTA DE SÍMBOLOS}

$\%$ - Por cento

$<$ - Menor

= - Igual

$>$ - Maior

\pm - Mais ou menos

$\leq$ - Menor ou igual

$\geq$ - Maior ou igual

${ }^{\circledR}$ - Registrado

$1 / 4$ - Um quarto

$C_{t}$ - Threshold cycle (ciclo do limiar)

IL-1 $\beta$ - Interleucina 1 beta

$\mathrm{KH}_{2} \mathrm{PO}_{4}$ - Fosfato monopotássico

$\mathrm{Na}_{2} \mathrm{HPO}_{4} \cdot 12 \mathrm{H}_{2} \mathrm{O}$ - Fosfato de sódio bibásico

$\mathrm{Na}_{2} \mathrm{SO}_{4}$ - Sulfato de sódio

${ }^{\circ} \mathrm{C}$ - Grau Celsius

$\mathrm{R}^{2}$ - Coeficiente de correlação

TM - Marca registrada

TNF- $\alpha$ - Fator de necrose tumoral-alfa

US\$ - Dólar americano

$\beta$ - Beta 


\section{SUMÁRIO}

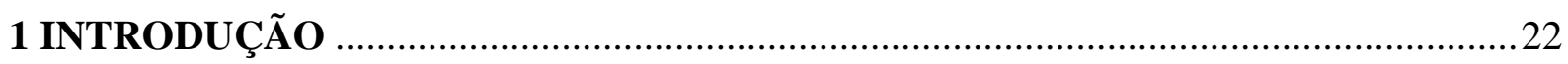

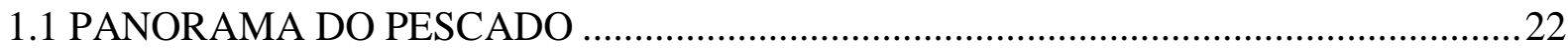

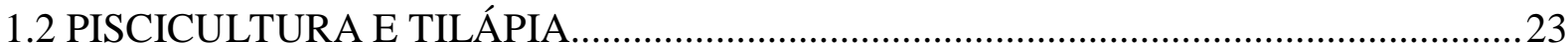

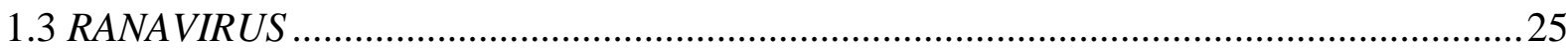

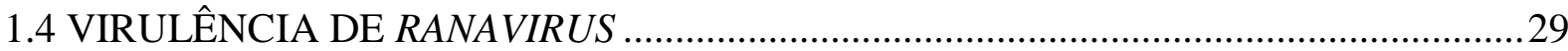

1.5 DISSEMINAÇÃO E IMPACTO DAS INFECÇÕES POR RANAVIRUS NO BRASIL...30

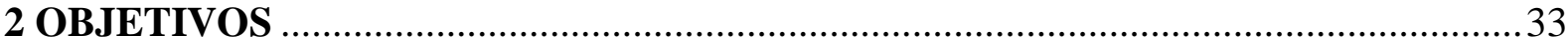

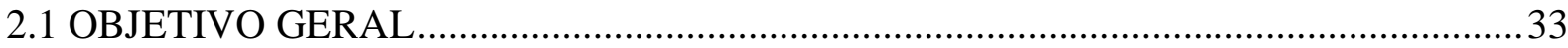

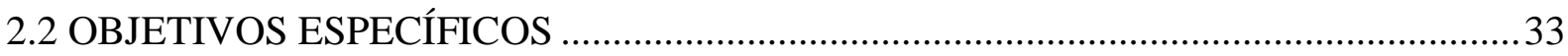

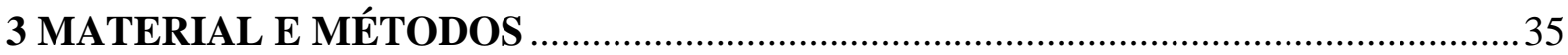

3.1 PEIXES UTILIZADOS NOS ENSAIOS DE INFECÇÃO EXPERIMENTAL .................36

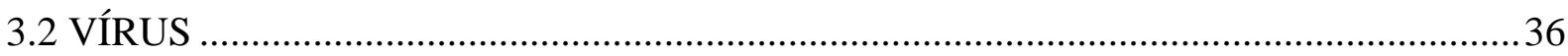

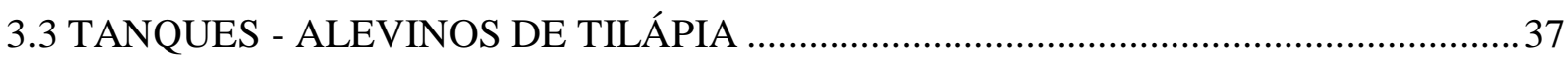

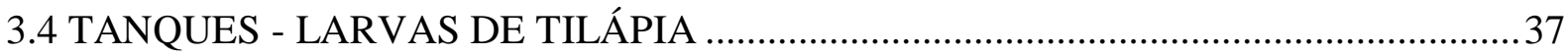

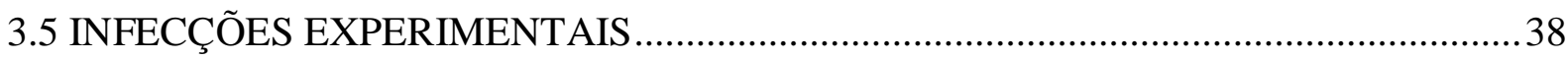

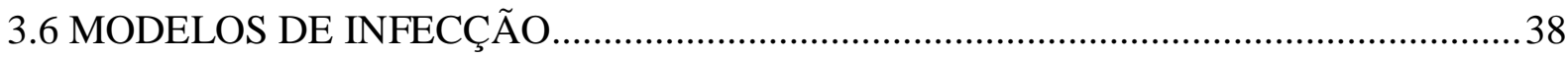

3.7 COLETA DE ANIMAIS PARA AS ANÁLISES PÓS-INFECÇÃO ................................39

3.8 ANÁLISES SANGUÍNEAS EM ALEVINOS DE TILÁPIA ..........................................40

3.9 BIOQUÍMICA PLASMÁTICA PARA AVALIAÇÃO DE ALTERAÇÕES HEPÁTICAS

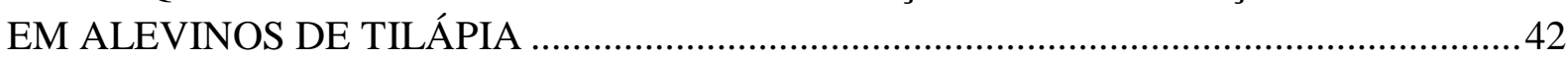

3.10 ÍNDICES SOMÁTICOS EM ÓRGÃOS DE ALEVINOS DE TILÁPIA........................42

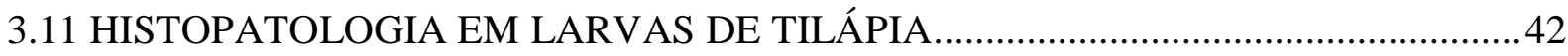

3.12 EXTRAÇÃO DE DNA DE LARVAS E ALEVINOS DE TILÁPIA...............................43

3.13 PCR CONVENCIONAL PARA RANAVIRUS EM LARVAS E ALEVINOS DE

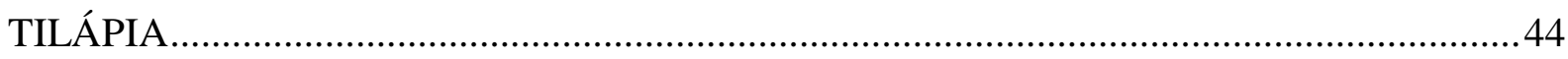

3.14 QPCR PARA QUANTIFICAÇÃO ABSOLUTA DE RANAVIRUS EM AMOSTRAS DE LARVAS E DE ALEVINOS DE TILÁPIA. 
3.14.2 Padronização e eficiência dos primers utilizados para quantificação absoluta através de PCR quantitativo em tempo real .............................................................46

3.14.3 Construção de curva padrão para quantificação absoluta em PCR quantitativo em tempo real

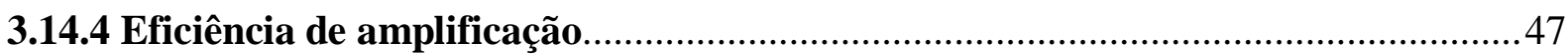

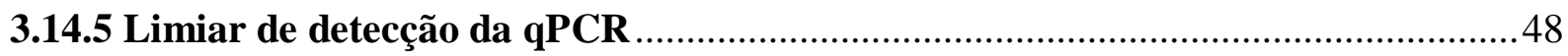

3.14.6 Quantificação da carga viral através de PCR quantitativo absoluto em tempo real

3.15 IMUNO-HISTOQUÍMICA EM LARVAS DE TILÁPIA .............................................49

3.16 HIBRIDIZAÇÃO IN SITU EM LARVAS DE TILÁPIA ..............................................50

3.17 SEQUENCIAMENTO DO GENOMA VIRAL DE ESTIRPE DE RANAVIRUS ...........52

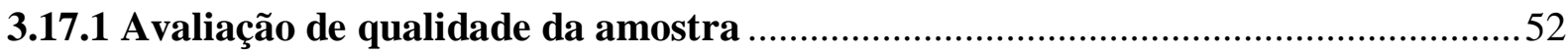

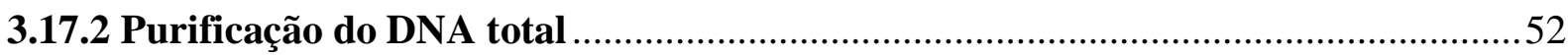

3.17.3 Preparo da biblioteca utilizando Nextera ${ }^{\circledR}$ XT DNA Library Prep Kit (Illumina, EUA)

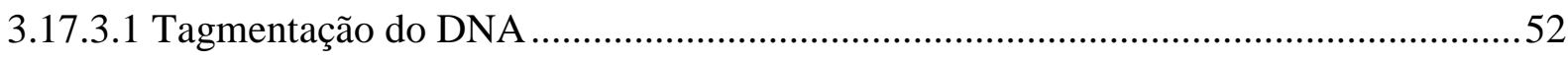

3.17.3.2 Amplificação do DNA e indexação........................................................................53

3.17.3.3 Purificação e quantificação da biblioteca ..................................................................53

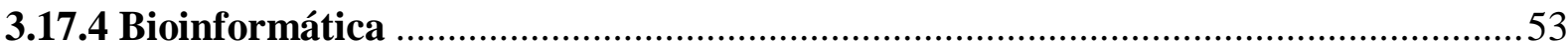

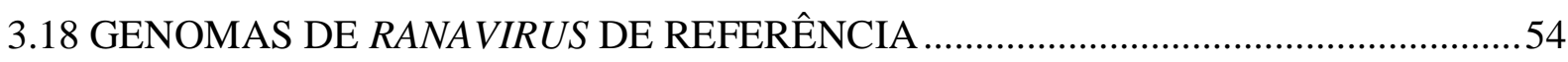

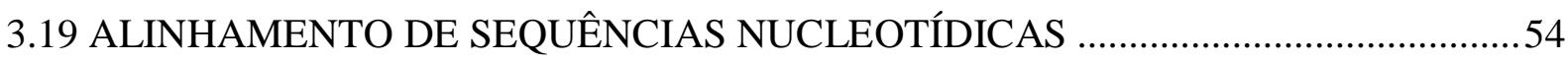

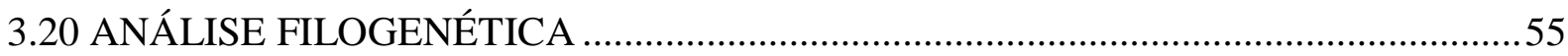

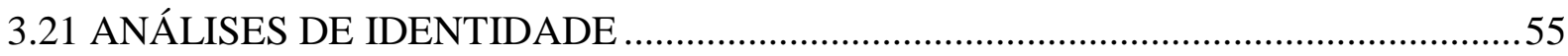

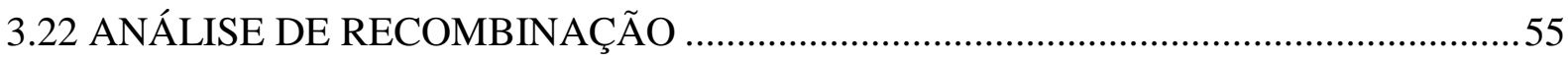

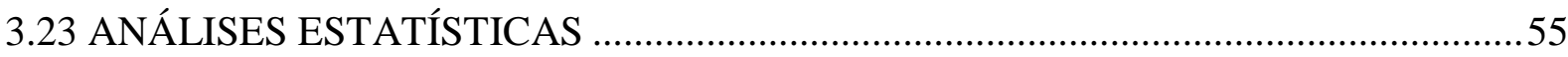

3.24 TRATAMENTO DA ÁGUA PÓS-EXPERIMENTOS ..................................................56

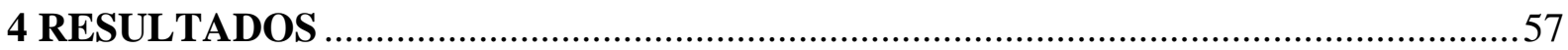

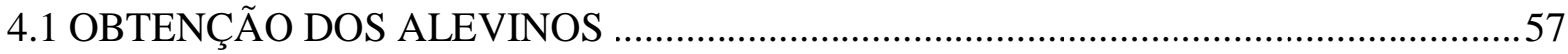


4.3 INFECÇÃO EXPERIMENTAL E VIAS DE INFECÇÃO ............................................58

4.4 COLETA DE ANIMAIS PARA AS ANÁLISES PÓS-INFECÇÃO .................................58

4.5 ANÁLISES HEMATOLÓGICAS EM ALEVINOS DE TILÁPIA...................................61

4.6 ESFREGAÇO SANGUÍNEO DE ALEVINOS DE TILÁPIA INFECTADOS EXPERIMENTALMENTE COM RANAVIRUS................................................................62

4.7 BIOQUÍMICA PLASMÁTICA EM ALEVINOS DE TILÁPIA .....................................66

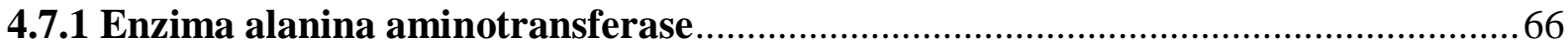

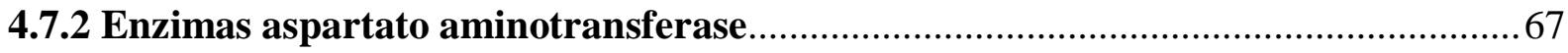

4.8 ÍNDICES SOMÁTICOS EM ÓRGÃOS DE ALEVINOS DE TILÁPIA..........................67

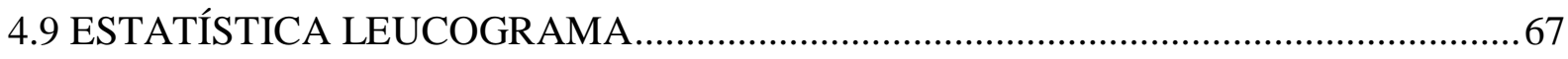

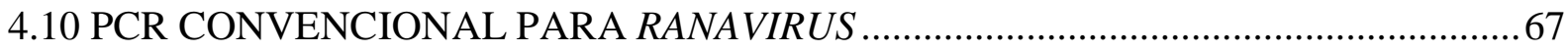

4.11 DETECÇÃO E QUANTIFICAÇÃO DA CARGA VIRAL ATRAVÉS DE PCR QUANTITATIVO EM TEMPO REAL EM LARVAS E ALEVINOS DE TILÁPIA DO NILO INFECTADOS EXPERIMENTALMENTE COM RANAVIRUS ..............................68

4.11.1 Padronização de eficiência dos primers utilizados para quantificação absoluta de Ranavirus através de PCR quantitativo em tempo real .................................................68

4.11.2 Curva padrão para PCR quantitativo absoluto em tempo real ............................69

4.11.3 Quantificação da carga viral através de PCR quantitativo absoluto em tempo real em animais experimentalmente infetados com Ranavirus FV3-like .............................. 71

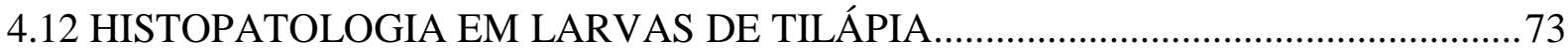

4.13 IMUNO-HISTOQUÍMICA EM LARVAS DE TILÁPIA ............................................78

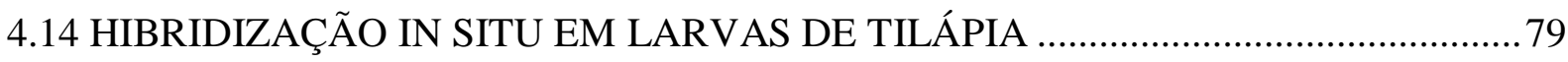

4.15 SEQUENCIAMENTO DE GENOMA VIRAL DE CEPA DE RANAVIRUS .................80

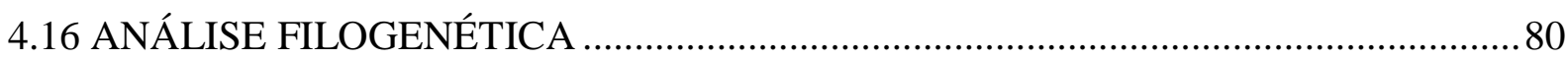

4.17 ANÁLISE DE IDENTIDADE DO GENE MCP ENTRE DIFERENTES ESPÉCIES DE RANAVIRUS.

4.18 ANÁLISE DE IDENTIDADE ENTRE GENOMAS DE RANAVIRUS 81

4.19 ANÁLISE DE RECOMBINAÇÃO ENTRE GENOMAS COMPLETOS DE RANAVIRUS FV3-LIKE. 
5 DISCUSSÃO

.86

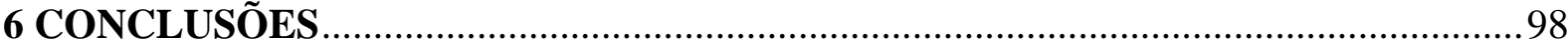

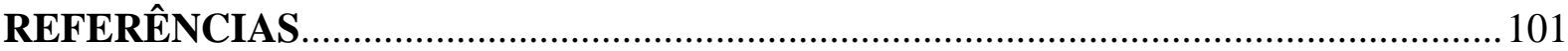

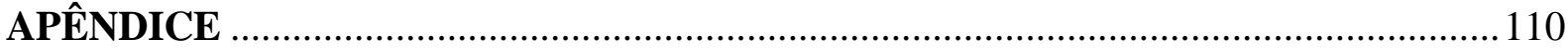




\section{INTRODUÇÃO}

\subsection{PANORAMA DO PESCADO}

O peixe é um alimento rico em nutrientes, possuindo proteínas de alta qualidade, retinol, potássio, iodo, selênio, ácidos graxos e também vitaminas D e E. Diversos estudos tem relacionado o consumo de peixes a um maior desenvolvimento cerebral e da aprendizagem em crianças, além de beneficiar a visão, proteger contra doenças cardiovasculares e determinados cânceres. Alguns nutrientes altamente benéficos são de difícil obtenção em outras fontes alimentares (FAO, 2000).

Mundialmente, o mercado de pescado é responsável por uma média de 60\% das exportações relacionadas a carnes, liderando o ranking comercial em relação à proteína animal (BRASIL, 2015). No ano de 2017, a quantidade de pescado produzido e comercializado mundialmente girou em torno de 172 milhões de toneladas; deste total, 80 milhões de toneladas foram provenientes de peixes de cultivo e 92 milhões de toneladas de peixes de captura. No mesmo ano, as produções mundiais de carne suína, de frango e bovina foram de 120, 118 e 70 milhões de toneladas, respectivamente. A produção global de peixes cultivados apresentou crescimento de 60\% na década de 2007 a 2017, saltando de 50 para os atuais 80 milhões de toneladas, enquanto a produção de peixes de captura se manteve estável no período, na faixa dos 90/92 milhões de toneladas/ano. Estima-se que entre os anos de 2020 a 2021 a aquicultura será responsável por pelo menos 51\% do total de pescado comercializado mundialmente. A elevação em termos percentuais desta modalidade se dá principalmente devido ao crescente consumo e a estagnação da pesca extrativista nos rios e oceanos, de modo que a sobrepesca colocaria em risco a sobrevivência de várias espécies de importância comercial. Para o ano de 2025, há uma perspectiva de produção mundial de 195 milhões de toneladas de pescado, sendo 102 milhões de toneladas (52,3\%) oriundas de peixes cultivados e 93 milhões de toneladas (47,7\%) provenientes da captura de espécimes (OCDE, 2017; FAO, 2017; ANUÁRIO PEIXEBR DA PISCICULTURA, 2018). Ao nível global, o Brasil é um dos poucos países que têm condições de atender a essa crescente demanda, principalmente através da aquicultura (FAO, 2014).

A produção de peixes no país atingiu 60,2\% de crescimento entre os anos de 2007 a 2009, de acordo com levantamento estatístico divulgado pelo extinto Ministério da Pesca e Aquicultura (ESALQ, 2016). Em relação ao consumo nacional de pescado e frutos do 
mar, este apresentou crescimento de 23,7\% entre os anos de 2010 a 2011, sendo que na última década, o aumento foi de quase 100\% (BRASIL, 2014); atualmente, o consumo está na faixa de 9,5kg por habitante/ano (ANUÁRIO PEIXEBR DA PISCICULTURA, 2018).

O setor pesqueiro no Brasil gera cerca de 3,5 milhões de empregos diretos e indiretos com uma média de 800 mil profissionais entre aquicultores e pescadores. Além disso, o país oferece condições extremamente favoráveis para ampliação da produção, conforme detalhado a seguir, e estas características podem tornar o país um dos maiores produtores mundiais de pescado: grandes bacias hidrográficas; represas de usinas hidrelétricas e de propriedades particulares somam 10 milhões de hectares de lâmina d’água; ampla reserva de água doce, correspondente a 13,7\% do total disponível no mundo; quatro milhões de quilômetros quadrados de zona econômica exclusiva; oito mil e quinhentos quilômetros de costa marítima e ambiente adequado para o desenvolvimento dos organismos cultivados, compreendendo inúmeras espécies de peixes, moluscos, crustáceos, algas e anfíbios (KUBITZA, 2015).

Somados todos estes fatores, em conjunto ao crescente consumo e ampliação dos preços no mercado mundial, há no país claras condições de se produzir proteína de alta qualidade e gerar milhões de novos empregos e renda de maneira sustentável. A produção de peixes no Brasil através da piscicultura teve crescimento de 16,3\% entre os anos de 2014 a 2017 e atualmente gera US\$ 1,5 bilhão em negócios (MUTEIA, 2009; ANUÁRIO PEIXEBR DA PISCICULTURA, 2018).

\subsection{PISCICULTURA E TILÁPIA}

A piscicultura é uma modalidade de cultivo de peixes que não exaure recursos hídricos, utiliza pouca terra, não desmata florestas e contribui ainda com o crescimento localizado da produção pesqueira (KUBITZA, 2007).

A produção brasileira de peixes cultivados no ano de 2017 correspondeu a 692 mil toneladas, sendo o Estado de São Paulo a terceira maior região produtora do país com 69,5 mil toneladas, um aumento de 6,3\% em comparação ao ano de 2016, de forma que esse montante equivale a $10 \%$ do mercado nacional. Do total de pescado cultivado no país em 2017, a produção de tilápia correspondeu a 51,7\% do total, equivalente a 358 mil toneladas, enquanto que a produção de peixes nativos (principalmente tambaqui, pirapitinga e pacu) correspondeu a 43,7\% do total, com 302 mil toneladas; outras espécies (em destaque as carpas 
e as trutas) representaram 4,6\% da produção nacional, com uma média de 32 mil toneladas (ANUÁRIO PEIXEBR DA PISCICULTURA, 2018).

A tilápia é um peixe tropical que tem melhor adaptação às águas rasas. São onívoros que se alimentam de plâncton, folhas verdes, organismos bentônicos, invertebrados aquáticos, larvas de peixes, detritos e matéria orgânica em decomposição. Os organismos naturais são responsáveis por 30 a 50\% do crescimento destes peixes, mesmo em viveiros com nutrição suplementar adequada. Podem filtrar alimentação por aprisionamento das partículas em suspensão, incluindo fitoplâncton e bactérias. A faixa de temperatura preferencial para engorda de tilápias gira em torno de $29-31^{\circ} \mathrm{C}$; já as temperaturas letais, inferior e superior, são de $11-12^{\circ} \mathrm{C}$ e $42^{\circ} \mathrm{C}$, respectivamente. A maturidade sexual é atingida por volta de 5-6 meses de idade. A desova inicia-se quando a temperatura da água alcança $24^{\circ} \mathrm{C}$. Uma fêmea de $100 \mathrm{~g}$ produz por volta de 100 ovos por desova, enquanto uma fêmea pesando 600-1000g pode produzir de 1000 a 1500 ovos (EL-SAYED, 2006). Tilápias podem alcançar um peso acima de 5 kg e viver por mais de 10 anos (FAO, 2012).

O cultivo da tilápia é atribuído há tempos no Antigo Egito, como descrito em baixo-relevo em uma tumba de mais de 4000 anos, onde é apresentada a criação destes peixes em lagos ornamentais. A distribuição mundial expressiva de tilápias, principalmente da espécie Oreochromis mossambicus ocorreu durante os anos 1940 e 1950 e, em relação à distribuição geográfica da tilápia do Nilo (Oreochromis niloticus), esta ocorreu mais intensamente entre as décadas de 1960, principalmente, e 1980 (FAO, 2014). A tilápia do Nilo é natural da África e foi introduzida no Brasil em 1971 (LOVSHIN, 2000). A partir do Brasil, foi enviada para os Estados Unidos em 1974. Em 1978, a tilápia do Nilo foi introduzida na China, atual líder mundial em produção deste pescado (1,8 milhão de toneladas em 2017). Diversas espécies de tilápia são cultivadas comercialmente; entretanto, a tilápia do Nilo (Oreochromis niloticus) é a espécie predominantemente cultivada em todo o mundo. Sua alta taxa de fecundidade, sustentabilidade ambiental e rusticidade são qualidades que beneficiam mundialmente sua criação. Além disso, é uma espécie com boa taxa de crescimento e altamente resistente a doenças. Estes peixes são criados desde sistemas extensivos até os mais modernos sistemas intensivos, em tanques, viveiros, gaiolas e tanques rede (FAO, 2014).

A produção global de tilápia apresentou crescimento de 6,9\% entre os anos de 2015 a 2017, passando de 5,3 para 5,7 milhões de toneladas. Para 2018, estima-se que a produção atinja 5,88 milhões de toneladas. No ano de 2016, somente os Estados Unidos 
importaram US\$ 1 bilhão em tilápias. Mundialmente, o Brasil é o quarto maior produtor de tilápias, com atuais 358 mil toneladas, volume alcançado no ano de 2017, ficando atrás da China (1,8 milhão de toneladas), Indonésia (1,1 milhão de toneladas) e Egito (800 mil toneladas) (ANUÁRIO PEIXEBR DA PISCICULTURA, 2018).

O cultivo brasileiro deste pescado se intensificou particularmente nas regiões Nordeste e Sudeste, apresentando crescimento próximo a 100\% em apenas quatro anos, de 35 mil toneladas em 2001 para 68 mil toneladas em 2005 (KUBITZA, 2007). Segundo o IBGE (2014), a produção nacional de tilápia está crescendo a uma taxa média de 17\% ao ano, com crescimento de 105\% entre os anos de 2003 a 2009. Atualmente, a região Sul do Brasil lidera a produção nacional deste pescado, sendo o Estado do Paraná o maior produtor, com 105 mil toneladas produzidas em 2017, que equivale a 94\% da produção de peixes do Estado; já o Estado de São Paulo (segundo maior produtor nacional) produziu no mesmo ano 66 mil toneladas de tilápia, correspondente a 95\% da produção de pescado do Estado (ANUÁRIO PEIXEBR DA PISCICULTURA, 2018).

Contudo, a viabilidade e competitividade do sistema de produção são diretamente ligadas à melhoria da produtividade e sanidade dos animais.

Alguns patógenos relacionados à piscicultura de tilápias podem trazer prejuízos por morte de animais infectados, pela diminuição da produtividade em decorrência de menores taxas de crescimento ou por redução do consumo de alimentos, de gastos com profissionais, de custos de tratamento e de prevenção. Além dos prejuízos financeiros, há o risco de danos às populações selvagens, derivando em mudanças no equilíbrio ecológico, perda de recursos genéticos animais e diminuição da biodiversidade (KUBITZA, 2013).

\subsection{RANAVIRUS}

Entre os principais patógenos virais, de distribuição mundial e de história recente, destacam-se os Ranavirus, sobre os quais os estudos no Brasil permanecem limitados.

Os Ranavirus fazem parte da família Iridoviridae que é dividida em cinco gêneros, dos quais três são considerados mais relevantes pela gravidade das infecções em animais aquáticos e semiaquáticos: Lymphocystivirus, Megalocytivirus e Ranavirus. São vírus envelopados e/ou não envelopados, apresentando DNA de fita dupla, cujo genoma varia de 102 a 212 kilobases (kb). Suas partículas virais possuem diâmetro de aproximadamente 120 a 
300 nanômetros $(\mathrm{nm})$ e podem ser encontradas tanto em água doce quanto salgada (WILLIAMS; BARBOSA-SOLOMIEU; CHINCHAR, 2005).

Os Ranavirus são considerados vírus emergentes devido ao recente aumento da incidência, geografia e gama de hospedeiros susceptíveis (DASZAK; CUNNINGHAM; HYATT, 2000). São capazes de infectar vertebrados ectotérmicos de três grupos taxonômicos diferentes: peixes teleósteos do qual Oreochromis niloticus faz parte, anfíbios e répteis (CHINCHAR, 2002). Além disso, alguns estudos indicam que, neste gênero, o mesmo vírus pode infectar animais de grupos taxonômicos distintos (MAO et al., 1999).

A ranavirose é reconhecida como uma das principais patologias de importância econômica e ecológica em vertebrados de sangue frio (CHINCHAR, 2002; WILLIAMS; BARBOSA-SOLOMIEU; CHINCHAR, 2005). Aliás, os Ranavirus são suspeitos de serem parcialmente responsáveis pelos declínios globais de populações de anfíbios (CHINCHAR, 2002).

No hospedeiro causam doença sistêmica que envolve múltiplos órgãos internos, principalmente os tecidos hematopoiéticos, os rins, o fígado, o baço e o trato digestório, causando hemorragias focais e necrose generalizada (WHITTINGTON; REDDACLIFF, 1995; WILLIAMS; BARBOSA-SOLOMIEU; CHINCHAR, 2005). Ranavirus também demonstraram induzir sinais clínicos característicos de apoptose em células hospedeiras, tais como condensação cromatínica e fragmentação de DNA (CHINCHAR, 2002). A via de transmissão, a carga viral e os fatores ambientais desempenham um papel importante no surgimento da doença. A infecção pode variar de subclínica a fulminante com letalidade próxima de 100\% (BRUNNER; RICHARDS; COLLINS, 2005; BRUNNER; SCHOCK; COLLINS, 2007).

Os vírus da família Iridoviridae estão emergindo como fatores preocupantes de mortalidade em populações naturais de répteis, anfíbios, peixes marinhos e de água doce de importância comercial, não estando claro se isso é resultado de alterações na transmissão ou virulência de patógenos endêmicos em populações imunossuprimidas, ou uma consequência da introdução de patógenos exóticos em áreas com novas espécies hospedeiras (WILLIAMS; BARBOSA-SOLOMIEU; CHINCHAR, 2005).

No Brasil, existem relatos de iridovirose em fazendas de cultivo de anfíbios. A doença foi caracterizada em girinos de Rana catesbeiana infectados por vírus apresentando aproximadamente $100 \%$ de similaridade em regiões específicas do genoma com o vírus FV3 (Frog virus 3), pertencente ao gênero Ranavirus (MAZZONI et al., 2009). Na América do 
Sul, há relatos também no Uruguai (GALLI et al., 2006). Nos Estados Unidos, as iridoviroses estão relacionadas à mortalidade em répteis, anfíbios e peixes (WOODLAND; NOYES; GRIZZLE, 2002; JOHNSON et al., 2008).

Uma das principais doenças em peixes em Singapura é causada pelo Singapore grouper iridovirus (SGIV), pertencente ao gênero Ranavirus (WILLIAMS; BARBOSA-SOLOMIEU; CHINCHAR, 2005; EATON; RING; BRUNETTI, 2010). Esta doença é tida como de gravidade extrema, por provocar perdas com alevinos, animais jovens e até animais de tamanho comercial (NAKAJIMA; MAENO, 1998).

Ariel e Owens (1997) analisaram a mortalidade causada por Ranavirus da espécie Bohle iridovirus (BIV) em alevinos de tilápia (Oreochromis mossambicus). Neste estudo, o vírus foi capaz de provocar letalidade próxima a 100\% em um período de 60 dias.

Smallmouth Bass (Micropterus dolomieu) infectados experimentalmente com Largemouth bass virus-like (LMBV-like, gênero Ranavirus, família Iridoviridae) resultou em alta morbidade e letalidade em todos os grupos infectados; a mortalidade de animais inoculados nas concentrações $10^{3}-10^{7}$ TCID 50 /peixe iniciou-se no segundo dia pósinfecção atingindo letalidade de 100\% em 14 dias (BOONTHAI et al., 2018).

Sivasankar et al. (2017) isolaram e caracterizaram um agente altamente virulento em peixes marinhos ornamentais na Índia. Análises através de PCR convencional para o gene Major Capsid Protein (MCP), seguidas por sequenciamento nucleotídico, mostraram uma identidade de 99,82\% com o Ranavirus LMBV-like.

Em peixes mandarim (Siniperca chuatsi) desafiados com três diferentes cepas da espécie Santee-Cooper ranavirus, 100\% de letalidade dos animais provocada pelos vírus foi observada (FU et al., 2017).

Mcgrogan et al. (1998) descreveram a infecção por iridovirus-like em tilápias do Nilo (Oreochromis niloticus). Os peixes apresentavam sintomas de letargia e constantemente descansavam no fundo do tanque. Macroscopicamente, os peixes exibiam edemas, brânquias pálidas e vários graus de exoftalmia. Uma grande quantidade de peixes também apresentava eritema na região submandibular da pele. Outra particularidade observada foi à pigmentação escura na superfície dos animais. As características internas predominantes foram: grave ascite abdominal e palidez marcante dos órgãos viscerais, principalmente do fígado. Alguns peixes também apresentaram hemorragias petequiais hepáticas. A particularidade mais relevante em microscopia óptica foi em relação à distribuição difusa de células hipertróficas aparentemente em tecidos de procedência 
mesodérmica. Neste estudo, 25 tilápias foram examinadas devido às altas taxas de mortalidade observadas em animais cultivados.

Aparentemente, a temperatura da água modifica o período de incubação em infecções experimentais com Ranavirus da espécie Epizootic haematopoietic necrosis virus (EHNV), realizadas tanto em perca europeia (Perca fluviatilis) como em trutas arco-íris (Oncorhynchus mykiss). Em adultos de perca europeia, o período de incubação entre 10 e 11 dias, em temperaturas variando de 19 a $21^{\circ} \mathrm{C}$, variou para 10 a 28 dias, em temperaturas entre 12 e $18^{\circ} \mathrm{C}$ (WHITTINGTON; REDDACLIFF, 1995). Entre percas europeias jovens utilizando o vírus EHNV, o período de incubação, em temperaturas entre 18 e $24^{\circ} \mathrm{C}$, variou de 3 a 6 dias (LANGDON, 1989). De maneira análoga, o período de incubação em trutas arcoíris variou de 3 a 10 dias, a temperaturas de 19 a $21^{\circ} \mathrm{C}$, contra 14 a 32 dias em temperaturas entre 8 e $10^{\circ} \mathrm{C}$. Outros fatores podem influenciar a ocorrência de infecção como aqueles observados em trutas arco-íris, entre eles, destacam-se as condições imunossupressoras associadas a más condições de cultivo, tais como: superpopulação, acúmulo de ração nos tanques, má qualidade e fluxo inadequado da água (WHITTINGTON; BECKER; DENNIS, 2010).

A detecção da ranavirose, inicialmente, baseia-se em um diagnóstico presuntivo macroscópico. Entretanto, os achados clínicos da doença não são patognomônicos, sendo um diagnóstico laboratorial confirmatório necessário. A presença de partícula icosaédrica de 120-300nm no citoplasma de células de animais sintomáticos, por microscopia eletrônica, levanta a suspeita de uma presumível infecção por Ranavirus. Técnicas tradicionais de imuno-histoquímica, isolamento viral e PCR são métodos práticos para o diagnóstico confirmatório (WILLIAMS; BARBOSA-SOLOMIEU; CHINCHAR, 2005).

Em relação aos anfíbios, a transmissão da ranavirose ocorre por vias diretas e indiretas incluindo exposição à água ou solo contaminados, contato com indivíduos infectados e ingestão de tecido infectado durante a predação, canibalismo ou necrofagia (GRAY; MILLER; HOVERMAN, 2009), porém também é dependente da carga viral (CHINCHAR et al., 2009). Estes métodos de disseminação são semelhantes aos encontrados por Kurobe et al. (2011), em experimentos realizados com esturjões Scaphirhynchus albus e Scaphirhynchus platorynchus, ao analisarem as formas de transmissão da iridovirose. A ingestão de tecido infectado e a coabitação foram as principais vias observadas. Ademais, os autores mostraram que mesmo após um período superior a oito semanas, peixes recuperados de casos clínicos foram capazes de transmitir o vírus para animais jovens por coabitação. Os 
vírus também podem se espalhar entre os sistemas fluviais e represamentos, incluindo a translocação de peixes vivos ou iscas por pescadores recreativos (WHITTINGTON et al., 1996).

Os Ranavirus são altamente resistentes à dessecação, podendo sobreviver por grandes períodos na água. Entretanto, são suscetíveis à solução de etanol 70\%, aquecimento a $60^{\circ} \mathrm{C}$ por 15 minutos ou a hipoclorito de sódio a 200mg/L (LANGDON, 1989). Whittington, Becker e Dennis (2010) citam diferentes estudos que apontam a eficácia de alguns desinfetantes contra Ranavirus isolados de anfíbios, tais como clorexidina, peroximonosulfato de potássio e hipoclorito de sódio.

\subsection{VIRULÊNCIA DE RANAVIRUS}

Embora os vírus do gênero Ranavirus sejam frequentemente reconhecidos por sua alta morbidade e alta letalidade, há uma grande variação da virulência entre diferentes estirpes virais e espécies hospedeiras (GRAY; CHINCHAR, 2015).

Um padrão que vem se tornando claro é que Ranavirus isolados de locais de produção de peixes são mais virulentos em relação às cepas selvagens ou de ambientes naturais. Por exemplo, uma cepa de ATV (Ambystoma tigrinum virus), - pertencente ao gênero Ranavirus, isolada de um depósito de iscas naturais de pesca foi significativamente mais virulenta às larvas de salamandra-tigre (Ambystoma tigrinum) em comparação às cepas nativas (STORFER et al., 2007). Hoverman et al. (2011) reportaram um Ranavirus FV3-like isolado de uma instalação comercial de rã-touro-americana (Lithobates catesbeianus) altamente virulento, causando uma letalidade em média 51\% maior em experimento utilizando oito espécies de larvas de anuro, comparado ao isolado selvagem de FV3. Nesta mesma linha, um Ranavirus isolado de um incubatório de esturjão está entre as estirpes mais virulentas de FV3 já identificadas (WALTZEK et al., 2014).

Alguns estudos apontam condições que favorecem a transmissão podem levar ao aumento da virulência. Dentre estas condições, destacam-se as altas taxas de contato entre hospedeiros em cativeiro e durante o transporte, podendo resultar na evolução da virulência dos Ranavirus (ALIZON et al., 2009). Também deve se levar em conta a competição entre patógenos dentro de um hospedeiro, fato que pode favorecer o aumento da virulência, mesmo ao custo da redução da transmissão (DE ROODE et al., 2005). Cativeiros que muitas vezes recebem animais de muitas fontes podem abrigar inúmeras estirpes de 
Ranavirus co-circulantes, com a implicação de selecionar as mais virulentas (ANTIA; LEVIN; MAY, 1994; BULL, 1994).

Embora todas essas hipóteses continuem a serem testadas, coletivamente, nota-se a necessidade de mudar as condições e práticas em instalações de cultivo que possam promover a transmissão, a mistura e a persistência dos Ranavirus (GRAY; CHINCHAR, 2015).

Comparações entre estirpes de FV3, intimamente relacionadas, que variam em virulência, sugerem que as diferenças intragênicas, bem como a variação dentro de sequências repetidas, podem influenciar a patogênese viral (MORRISON et al., 2014). A virulência é uma característica que envolve múltiplos fatores, mas dois que são mais importantes envolvem aqueles que melhoram a replicação do vírus e aqueles que bloqueiam as defesas imunológicas do hospedeiro. Grandes vírus de DNA, como herpesvírus e poxvírus, codificam numerosos genes que realizam essas funções e conclusões preliminares sugerem que Ranavirus não são diferentes (EATON et al., 2007).

O desafio de identificar proteínas de virulência por pesquisas de similaridade com sequências deduzidas de aminoácidos de genes reguladores ou ativadores de respostas celulares é considerável. Como o nível de similaridade entre homólogos virais e celulares pode ser baixo, a identificação de uma proteína viral como um potencial inibidor de uma função específica da célula está longe de ser certa, a menos que sequências-chave estejam conservadas. Para uma determinada proteína viral, evidências conclusivas para um papel específico, em termos de virulência, exigirão o uso de abordagens genômicas e bioquímicas. Claramente, os Ranavirus codificam um grande número de produtos gênicos que representam tanto potenciais fatores de virulência quanto alvos promissores para futuras intervenções terapêuticas. O advento da qPCR vem proporcionando avanços significativos no estudo de vários patógenos e sua virulência (GRAY; CHINCHAR, 2015).

\subsection{DISSEMINAÇÃO E IMPACTO DAS INFECÇÕES POR RANAVIRUS NO BRASIL}

Um dos problemas associados à expansão da tilapicultura no Brasil é a importação de tilápias de melhor desempenho produtivo, oriundas de países com tradição na criação e melhoramento genético destes peixes. Devido aos riscos relacionados à importação, o comércio internacional de alevinos está sujeito a rígidos parâmetros zoossanitários. Em tempo, os Ranavirus adentram à lista de patógenos de notificação obrigatória da World 
Organisation for Animal Health, para anfíbios, representando potencial perigo associado à importação de alevinos de tilápia (OIE, 2014).

Chinchar et al. (2009) fazem referência a casos de disseminação de iridoviroses oriundas da exportação de peixes de Singapura para diversos países como: Austrália (1988), Canadá (1989), Reino Unido (1997) e Israel (2001).

Em estudo canadense de caso de Mcgrogan et al. (1998), tilápias da espécie Oreochromis niloticus foram analisadas devido a altas taxas de mortalidade observadas. Esta ocorrência se deu em razão de surto que se descobriu ser provocado por iridovirus. Os animais haviam sido importados pelo Canadá a partir da Flórida (EUA).

A probabilidade de difusão da ranavirose para o Brasil por meio da importação de matrizes e reprodutores pode ser considerada moderada, fazendo-se necessária a avaliação da exposição e mortalidade dos hospedeiros por este agente patogênico (OIE, 2014).

Dentre os peixes cultivados no Brasil, sabe-se que a tilápia é suscetível aos vírus da família Iridoviridae (MCGROGAN et al., 1998). Além disso, não se pode ignorar a grande biodiversidade de peixes nativos do Brasil que poderiam ser suscetíveis a estes agentes. Recentemente, foram relatados casos de ranavirose (espécie Frog virus 3) em tilápias e em anfíbios no país. O estudo envolveu a detecção e a caracterização moleculares, a partir de peixes e de anfíbios de diferentes regiões brasileiras, provenientes de animais que vieram a óbito e de animais altamente debilitados que apresentavam sinais clínicos característicos de infecção pelo vírus (ALMEIDA-QUEIROZ et al., 2014). O isolamento viral em cultura de células também foi realizado (ALENCAR, 2016). Estes estudos foram desenvolvidos no Laboratório de Higiene Zootécnica da Faculdade de Zootecnia e Engenharia de Alimentos da Universidade de São Paulo (FZEA/USP).

Fatores predisponentes para a disseminação de ranavirose no Brasil estão associados aos sistemas usuais de cultivo de peixes como tanques escavados, permitindo que outros vertebrados como répteis e anfíbios tenham contato com o vírus e se tornem fontes de infecção para outros tanques ou para outros animais da região, ou ainda por tanques rede, permitindo o contato entre peixes de interesse comercial com as demais espécies, adicionado ao fato de que a ranavirose pode ser transmitida por contato direto, por coabitação ou via oral. Até mesmo peixes que se recuperaram da infecção, após um período superior a oito semanas (KUROBE et al., 2011), propiciaram condições ideais para que a exposição do vírus a animais 
suscetíveis fosse elevada. Nesse sentido, fazem-se necessários o rastreamento e investigação da patogenicidade das estirpes de Ranavirus circulantes no país.

Em relação ao impacto econômico em tilápias, a infecção por Ranavirus apresenta elevadas taxas de letalidade (ARIEL; OWENS, 1997). Já em trutas, elevadas taxas de morbidade são observadas. Implicações semelhantes são possíveis para as espécies nativas que forem expostas. Desse modo, o impacto gerado pela ranavirose na população piscícola pode ser considerado alto (WILLIAMS; BARBOSA-SOLOMIEU; CHINCHAR, 2005; CHINCHAR et al., 2009; NOGA, 2010), requerendo-se medidas de controle e profilaxia higiênico-sanitárias mais restritivas. Por outro lado, os Ranavirus não causam infecções em animais de sangue quente e, portanto, não representam risco à saúde pública (CHINCHAR, 2002).

Não obstante, em concordância com Whittington, Becker e Dennis (2010), fatores como a caracterização taxonômica, gama de hospedeiros suscetíveis, persistência no ambiente, taxas de transmissão e sensibilidade de testes de diagnóstico são notoriamente importantes para a ampliação dos conhecimentos sobre a ranavirose no país, tornando-se premente a caracterização e análise genética de estirpe viral circulante no Brasil e a realização de investigações no âmbito da patogênese da infecção desse agente viral em espécies de peixes de interesse zootécnico, tendo-se como destaque a tilápia. 


\section{OBJETIVOS}

\subsection{OBJETIVO GERAL}

O presente estudo objetivou caracterizar a patogenicidade, por meio da infecção experimental de larvas e alevinos de tilápia do Nilo (Oreochromis niloticus) com estirpe de Ranavirus (Frog virus 3-like) recentemente detectada e isolada no Brasil, incluindo o sequenciamento e análise do genoma da estirpe viral utilizada.

\subsection{OBJETIVOS ESPECÍFICOS}

1. Realizar infecções experimentais com Ranavirus FV3-like em larvas e alevinos de tilápia do Nilo através de 3 diferentes modelos de infecção (injeção intraperitoneal, coabitação e diluição do vírus nas águas dos animais) utilizando 4 diferentes concentrações infectantes.

2. Analisar perfil hematológico e de bioquímica sérica em alevinos de tilápia infectados com Ranavirus FV3-like, a fim de se analisarem as variações quantitativas e morfológicas dos elementos sanguíneos e mensuração dos níveis das enzimas ALT (alanina aminotransferase) e AST (aspartato aminotransferase) associadas à função hepática.

3. Determinar os índices hepato-somáticos (IHS) e espleno-somáticos (IES) para avaliação de distúrbios hepáticos e esplênicos em alevinos de tilápia experimentalmente infectados com Ranavirus FV3-like.

4. Realizar exames histopatológicos a partir de tecidos (fígado, baço, rim, coração e intestino) de larvas de tilápia desafiadas com Ranavirus FV3-like, avaliando-se as lesões em relação às diferentes concentrações infectantes utilizadas e período pós-infecção.

5. Realizar PCR (reação em cadeia pela polimerase) quantitativo em tempo real (qPCR) para quantificação de Ranavirus em animais experimentalmente infectados (larvas e alevinos de tilápia do Nilo), considerando-se as diferentes concentrações infectantes utilizadas, vias de infecção e período pós-infecção.

6. Realizar ensaios imuno-histoquímicos e de hibridização in situ para detecção de antígenos e sequências de DNA de Ranavirus, respectivamente, em tecidos de larvas de tilápia 
desafiadas com Ranavirus FV3-like, associando os possíveis dados dessas técnicas com os dados histopatológicos.

7. Realizar o sequenciamento completo de estirpe de Ranavirus FV3-like recentemente detectada no Brasil, isolada e utilizada nos processos de infecção experimental, a fim de se caracterizar o genoma de estirpe viral circulante no país. 


\section{MATERIAL E MÉTODOS}

Imagem 1 - Fluxograma de atividades desenvolvidas na presente tese de doutorado.

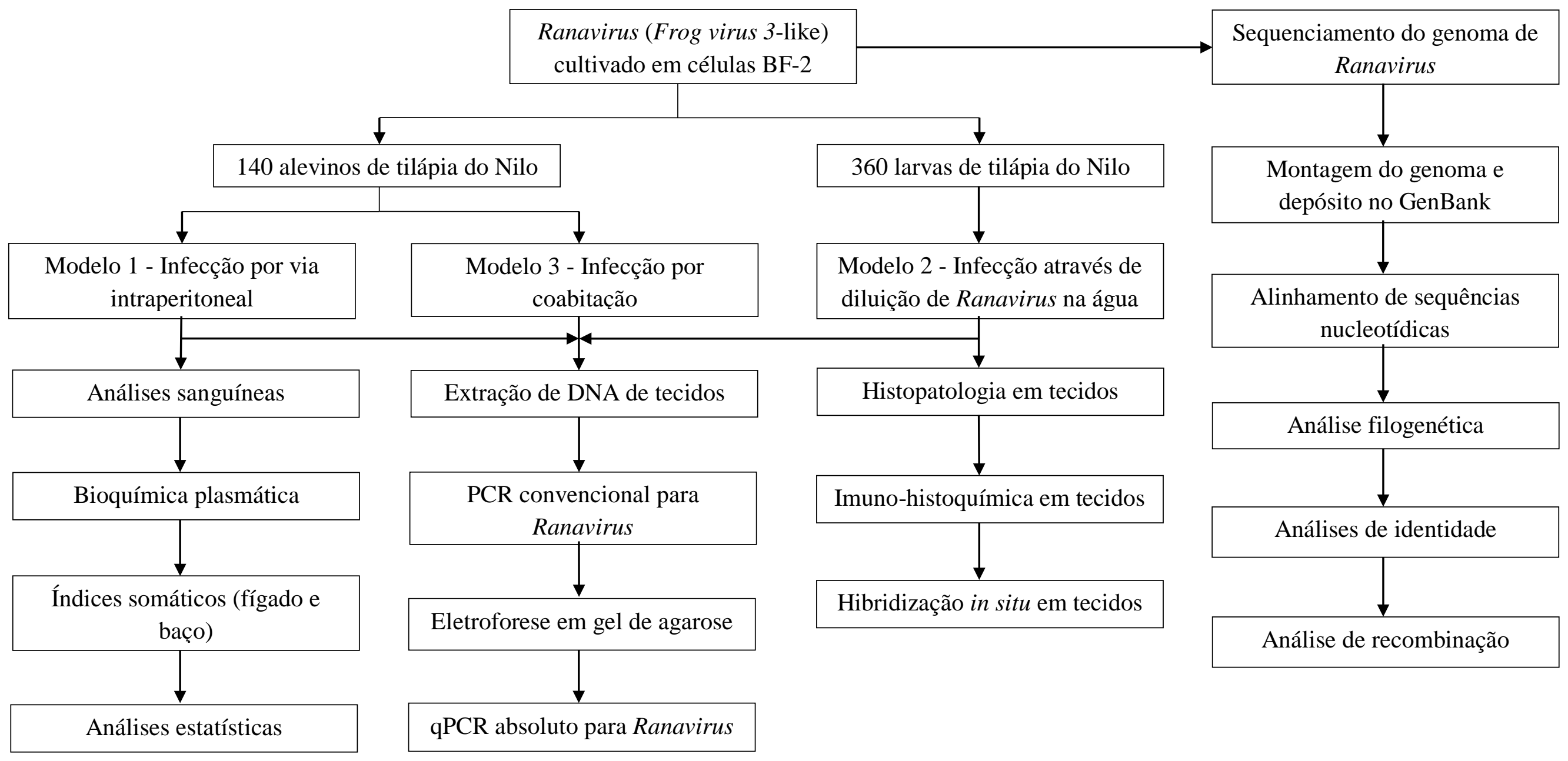

Fonte: Própria autoria. 
O presente trabalho foi aprovado pela Comissão de Ética no Uso de Animais (CEUA) da Faculdade de Zootecnia e Engenharia de Alimentos da Universidade de São Paulo - FZEA/USP em 18 de novembro de 2015, sob processo de número: 2910141015.

\subsection{PEIXES UTILIZADOS NOS ENSAIOS DE INFECÇÃO EXPERIMENTAL}

Neste estudo, foram utilizados 140 alevinos e 360 larvas de tilápia do Nilo (Oreochromis niloticus) criadas em sistema fechado (Piscicultura Polettini, localizada em Mogi Mirim - SP), cujos animais foram previamente testados para Ranavirus através de PCR convencional, conforme descrito a seguir (item 3.13).

\subsection{VÍRUS}

Os Ranavirus (Frog virus 3-like) utilizados nas infecções experimentais foram detectados em criadouro comercial de anfíbios no Estado de São Paulo, Brasil e isolados em células BF-2 (bluegill fry ATCC ${ }^{\circledR}$ CCL-91 ${ }^{\mathrm{TM}}$ ) no Laboratório de Higiene Zootécnica - FZEA/USP (ALMEIDA-QUEIROZ et al., 2014; ALENCAR, 2016), sendo mantidos em cultivos de células da mesma linhagem (imagem 2). Foram realizadas sete passagens virais em células antes da utilização nos processos de infecção experimental. 
Imagem 2 - Micrografia eletrônica de transmissão de cultivo de células BF-2 infectadas com cepa de Ranavirus (Frog virus 3-like) utilizada nos processos de infecção experimental.

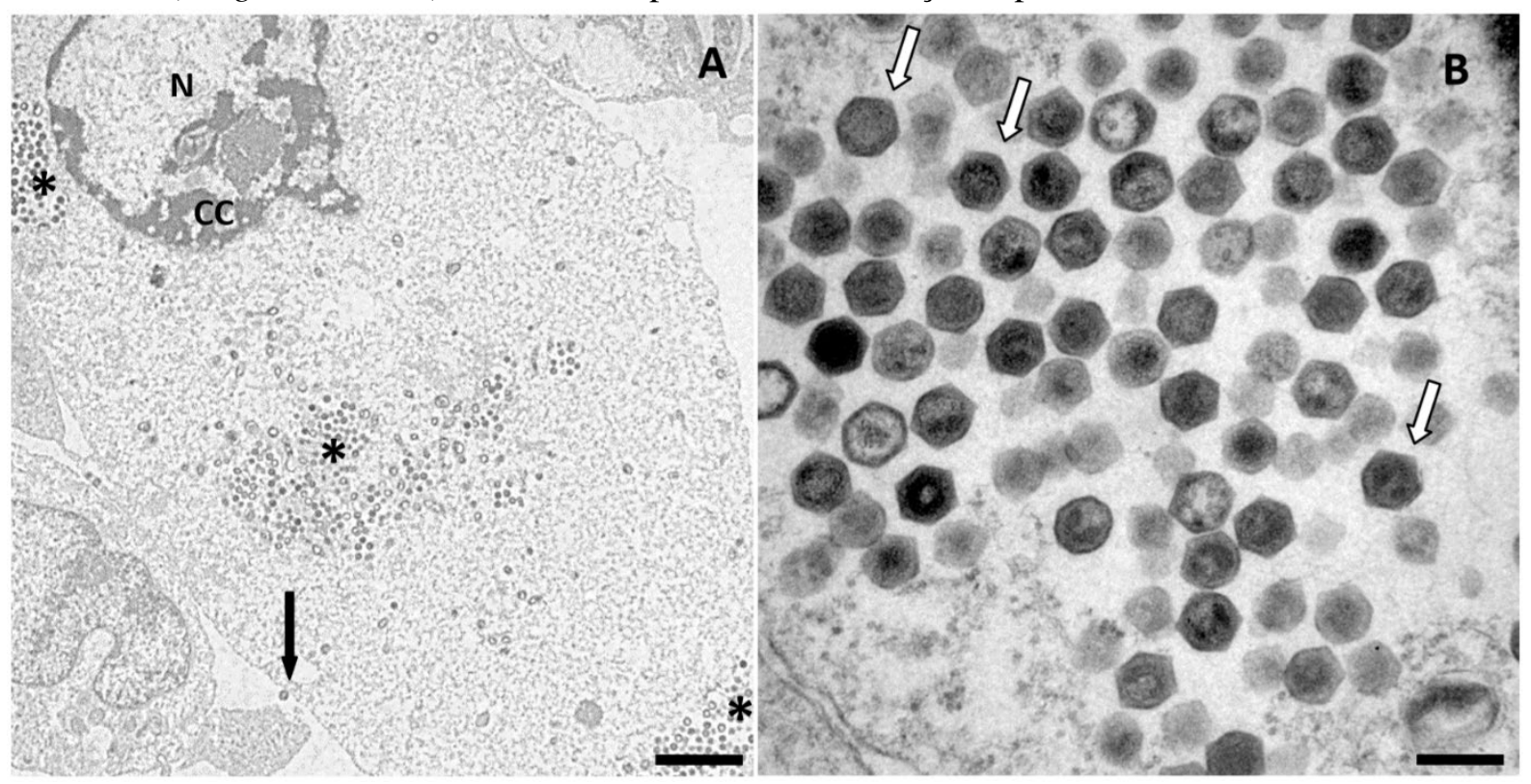

Legenda - A: núcleo (N), condensação de cromatina (CC), indicando apoptose, sítios de montagem de partículas virais em conjunto com arranjos paracristalinos $(*)$ e partícula viral brotando da membrana plasmática (seta). B: grande número de virions icosaédricos citoplasmáticos com morfologia consistente com iridovírus (setas brancas).

Barra $=900 \mathrm{~nm}(\mathrm{~A})$ e 200nm (B).

Fonte: ALENCAR, 2016.

\subsection{TANQUES - ALEVINOS DE TILÁPIA}

Os alevinos de tilápia foram mantidos em sete tanques de 100 litros cada, separados em 20 animais por tanque. Os tanques eram ligados em sistema fechado de circulação de água, com aquecimento controlado por sistema digital integrado, para manter a temperatura da água constante $\left(26^{\circ} \mathrm{C}\right)$. O sistema de circulação estava acoplado à central de aeração e filtragem físico-biológica, para a manutenção da qualidade da água. O oxigênio, a temperatura e o pH eram aferidos duas vezes ao dia e a cada semana. Os peixes recebiam ração comercial peletizada duas vezes ao dia contendo $28 \%$ de proteína bruta (Laguna Socil $\left.{ }^{\circledR}\right)$.

\subsection{TANQUES - LARVAS DE TILÁPIA}

As larvas de tilápia foram mantidas em 12 tanques de 30 litros cada, separadas em uma média de 30 animais por tanque. Os tanques eram ligados em sistema 
fechado de circulação de água, com aquecimento controlado por sistema digital integrado, para manter a temperatura da água constante $\left(26^{\circ} \mathrm{C}\right)$. O sistema de circulação estava acoplado à central de aeração e filtragem físico-biológica, para a manutenção da qualidade da água. O oxigênio, a temperatura e o pH eram aferidos duas vezes ao dia e a cada semana. Os peixes recebiam ração comercial peletizada contendo $28 \%$ de proteína bruta (Laguna - Socil ${ }^{\circledR}$ ), duas vezes ao dia.

\subsection{INFECÇÕES EXPERIMENTAIS}

Os procedimentos de infecção experimental se iniciaram após a total adaptação dos animais aos tanques, que correspondeu a 11 dias após a introdução, no caso das larvas, e 30 dias, no caso dos alevinos de tilápia.

Alíquotas de cultivo celular infectado apresentando entre 80 a $90 \%$ de efeito citopático (CPE) foram colhidas e centrifugadas a $2000 \times g$ durante $10 \mathrm{~min}$ a $4^{\circ} \mathrm{C}$, sendo os sobrenadantes armazenados a $-80^{\circ} \mathrm{C}$. Os títulos virais foram quantificados por meio da determinação da dose infectante em cultura de células (TCID $\left.{ }_{50} / \mathrm{mL}\right)$, de acordo com Reed e Muench (1938). Células BF-2 foram utilizadas para a determinação dos títulos virais. O inóculo viral utilizado nos procedimentos de infecção apresentava título de $10^{5,8} \mathrm{TCID}_{50} / \mathrm{mL}$.

\subsection{MODELOS DE INFECÇÃO}

Os peixes foram submetidos a três diferentes modelos de infecção:

Modelo 1. Alevinos de tilápia foram anestesiados por imersão em solução aquosa de benzocaína na proporção de 160mg para cada litro de água. Após a insensibilização, os peixes foram infectados com Ranavirus utilizando quatro diferentes concentrações $\left(10^{1}, 10^{2}, 10^{3}\right.$ e $10^{4}$ TCID $\left.50 / \mathrm{mL}\right)$, através de inoculação por via intraperitoneal de 0,1 mL, sendo reservados 20 animais para cada concentração infectante. O grupo controle (20 animais) foi inoculado com sobrenadante de cultivo celular não infectado. Cinco, do total de sete tanques contendo alevinos de tilápia, foram utilizados neste modelo de infecção.

Modelo 2. O modelo de infecção utilizado em larvas de tilápia foi através de diluição de Ranavirus cultivado em células BF-2 nas águas dos tanques dos animais, empregando quatro diferentes concentrações $\left(10^{1}, 10^{2}, 10^{3}\right.$ e $\left.10^{4} \mathrm{TCID}_{50} / \mathrm{mL}\right)$, sendo 
reservado uma média de 60 animais para cada concentração infectante. No grupo controle (120 animais), foi utilizado sobrenadante de cultivo celular não infectado, e o mesmo modelo de infecção. Todos os tanques contendo larvas de tilápia foram utilizados neste modelo de infecção.

Modelo 3. Foi realizado um teste de infecção cruzada ou coabitação. Para tanto, três alevinos de tilápia com cerca $30 \mathrm{~g}$, selecionados aleatoriamente de um dos tanques sem animais infectados, conforme descrito no item 3.3, foram anestesiados (vide item 3.6, modelo 1) e infectados com Ranavirus na concentração de $10^{4}$ TCID $50 / m L$, através de inoculação por via intraperitoneal de $0,1 \mathrm{~mL}$ e identificados com um corte na nadadeira caudal. Estes animais foram realocados em tanque juntamente com os demais, nas condições de criação anteriormente citadas (item 3.3). O controle foi constituído por animais inoculados com sobrenadante de cultivo celular não infectado no mesmo modelo do experimento. Dois do total de sete tanques contendo alevinos de tilápia foram utilizados neste modelo de infecção. Os tanques foram separados dos demais no momento inicial do teste e permaneceram até o final da fase experimental.

A mortalidade foi registada diariamente em todos os modelos de infecção, sendo os peixes moribundos ou mortos recolhidos e congelados a $-80^{\circ} \mathrm{C}$ até a realização das análises subsequentes.

\subsection{COLETA DE ANIMAIS PARA AS ANÁLISES PÓS-INFECÇÃO}

Modelo 1. Dois alevinos de tilápia foram coletados de cada tanque nos dias 4, 12, 18, 25, 38 e 60 pós-infecção com Ranavirus FV3-like. Os animais foram anestesiados por imersão em solução aquosa de benzocaína na proporção de 200mg para cada litro de água. Após a insensibilização, foi coletado $1 \mathrm{~mL}$ de sangue de cada animal através de punção caudal, com auxílio de duas seringas de $1 \mathrm{~mL}$ banhadas em anticoagulante (EDTA 3,0\%), sendo coletado 0,5mL em cada seringa. Logo após a coleta sanguínea, os animais foram eutanasiados através de concussão cerebral, seguido de perfuração craniana e examinados individualmente. Posteriormente, foram extraídos o baço, o fígado, uma porção do rim dorsal e uma porção do rim cranial e congelados a $-80^{\circ} \mathrm{C}$, a fim de serem submetidos a análises subsequentes. 
Modelo 2. As coletas de larvas de tilápia para a realização das análises ocorreram da seguinte forma: quatro peixes de cada tanque foram coletados nos dias 4, 12, 18, 25, 38 e 60 após a infecção experimental. Os animais foram anestesiados por imersão em solução aquosa de benzocaína na proporção de 200mg para cada litro de água. Após a insensibilização, os animais foram eutanasiados através de concussão cerebral, seguido de perfuração craniana. Na sequência, cada animal foi observado morfologicamente para verificação de alterações macroscópicas. Dois animais inteiros mais o fígado, o baço, o coração, parte do rim dorsal e fragmentos do intestino de outras duas larvas de tilápia foram separados para a realização de análises posteriores.

Modelo 3. Nos dias 15, 30, 45 e 60 pós-infecção, três animais, dentre aqueles que coabitaram com os infectados inicialmente, do referido tanque experimental e tanque controle foram anestesiados por imersão em solução aquosa de benzocaína, na proporção de 200mg para cada litro de água. Após a insensibilização, os animais foram eutanasiados através de concussão cerebral, seguido de perfuração craniana e examinados individualmente. Foram extraídos o baço, o fígado, uma porção do rim dorsal e uma porção do rim cranial dos mesmos e congelados a $-80^{\circ} \mathrm{C}$ até o momento do uso. O material genético destes órgãos foi submetido a análises moleculares para detecção e quantificação de Ranavirus, conforme descrito a seguir (itens 3.13 e 3.14).

\subsection{ANÁLISES SANGUÍNEAS EM ALEVINOS DE TILÁPIA}

A partir do sangue coletado em uma das seringas (item 3.7, modelo 1) foi realizado o hemograma para verificação de parâmetros: contagem total de eritrócitos, dosagem de hemoglobina, determinação de hematócrito, cálculo de índices hematimétricos absolutos, contagem total de leucócitos e contagem diferencial de leucócitos.

O hematócrito foi realizado em microcentrífuga (Hematrocrit, Centribio, EUA), centrifugando-se o tubo capilar de vidro preenchido com sangue por 5 min a $15000 \times$ g. A dosagem de hemoglobina foi efetivada pelo método cianocobalamina, com o uso de kit comercial (Hemoglobina, Referência 43 - Labtest, Brasil) e equipamento semiautomático (Bio 2000, Bioplus, Brasil), sendo o resultado obtido em g/dL. A calibração foi realizada com o uso de padrão de hemoglobina comercial (Referência 47 - Labtest, Brasil). Após o preparo das amostras com o reativo comercial e a incubação por 5 min a temperatura ambiente, os 
tubos foram centrifugados durante 15 min a $1300 \times g$ para a decantação dos núcleos de eritrócitos e posterior leitura em espectrofotômetro.

A dosagem de proteína plasmática total foi realizada por refratometria (Refratômetro Manual, Quimis, Brasil) e o resultado expresso em g/dL. A contagem do número total de eritrócitos e leucócitos foi realizada em câmara de Neubauer modificada, segundo a técnica de Natt e Herrick (CAMPBELL, 1994; CARDOSO; TESSARI, 2003; LANZAROT et al., 2005), sendo o resultado expresso em número de células por $\mu \mathrm{L}$.

O sangue total em EDTA foi homogeneizado e diluído com a solução de Natt e Herrick (1952) na razão de 1:200 (4mL de diluente e $20 \mu \mathrm{L}$ de sangue). A amostra foi homogeneizada e a câmara de Neubauer preenchida. Os eritrócitos foram contados em 5 campos do quadrante central da câmara de Neubauer, utilizando-se objetiva de 40X de microscópio óptico (Primo Star, Zeiss, Alemanha), sendo o fator de correção utilizado 10.050. Os leucócitos foram contados nos 4 quadrantes laterais da câmara de Neubauer, utilizando-se objetiva de 40X do microscópio óptico (Primo Star, Zeiss, Alemanha), sendo o fator de correção utilizado 502,5.

A contagem diferencial de leucócitos e as avaliações morfológicas dos elementos figurados do sangue foram realizadas em esfregaços sanguíneos corados pelo método de Rosenfeld (BIRGEL, 1982). Foram contados 100 leucócitos diferenciando-os em neutrófilos, eosinófilos, basófilos, linfócitos e monócitos. O valor absoluto de leucócitos foi obtido através do número total de leucócitos $(/ \mu \mathrm{L})$ multiplicado pelo número relativo (\%) dividido por 100 .

Os reagentes foram dissolvidos em água destilada, na ordem em que se apresentam na tabela 1, completando o volume até $1000 \mathrm{~mL}$ com água destilada. A solução permaneceu em repouso (overnight) e foi filtrada antes do uso, apresentando $\mathrm{pH}$ de 7,3.

Tabela 1 - Solução de Natt e Herrick para contagem de eritrócitos e leucócitos utilizada na presente investigação.

\begin{tabular}{cc}
\hline Reagente & Quantidade \\
\hline $\mathrm{NaCl}$ & $3,88 \mathrm{~g}$ \\
$\mathrm{Na}_{2} \mathrm{SO}_{4}$ & $2,50 \mathrm{~g}$ \\
$\mathrm{Na}_{2} \mathrm{HPO}_{4} \cdot 12 \mathrm{H}_{2} \mathrm{O}$ & $2,91 \mathrm{~g}$ \\
$\mathrm{KH}_{2} \mathrm{PO}_{4}$ & $0,25 \mathrm{~g}$ \\
Formalina (37\%) & $7,50 \mathrm{~mL}$ \\
Violeta de metila & $0,10 \mathrm{~g}$ \\
Água destilada q.s.p. & $1000 \mathrm{~mL}$ \\
\hline
\end{tabular}

Fonte: NATT; HERRICK, 1952. 


\subsection{BIOQUÍMICA PLASMÁTICA PARA AVALIAÇÃO DE ALTERAÇÕES HEPÁTICAS EM ALEVINOS DE TILÁPIA}

O sangue coletado na seringa restante (item 3.7, modelo 1) foi transferido para microtubo previamente identificado e, em seguida, centrifugado a $1000 \times g$ por $15 \mathrm{~min}$, a $4^{\circ} \mathrm{C}$, para a obtenção do plasma sanguíneo.

Através do plasma, foram analisadas as atividades das enzimas ALT (alanina aminotransferase) e AST (aspartato aminotransferase) para a verificação de alterações no parênquima hepático. As dosagens de ALT e AST foram realizadas com o plasma em EDTA utilizando kits comerciais (Ref. 109 e 108, Labtest, Brasil), por meio do método de referência proposto pela International Federation of Clinical Chemistry and Laboratory Medicine (UV-IFCC), com posterior leitura em equipamento semiautomático (Bio 2000, Bioplus, Brasil).

\subsection{0 ÍNDICES SOMÁTICOS EM ÓRGÃOS DE ALEVINOS DE TILÁPIA}

Os índices somáticos foram calculados através da pesagem do fígado e do baço de alevinos de tilápia (item 3.7, modelo 1). Segundo Quentel e Obach (1992), a determinação dos valores padrão para a relação hepato-somática (IHS) e espleno-somática (IES) em peixes é importante para compreensão dos distúrbios hepáticos e esplênicos que podem ocorrer durante os processos patológicos.

Os índices (IHS) e (IES) foram calculados através da seguinte fórmula:

$$
\text { Índice Somático }(\%)=\quad \begin{gathered}
\text { Peso do órgão } \\
\text { Peso total do animal }
\end{gathered} \times 100
$$

Fonte: QUENTEL; OBACH, 1992.

\subsection{HISTOPATOLOGIA EM LARVAS DE TILÁPIA}

As análises histopatológicas foram realizadas no Laboratório Interinstitucional de Sanidade em Aquicultura do Centro de Pesquisa e Desenvolvimento em Sanidade Animal, do Instituto Biológico, da Secretaria da Agricultura e Abastecimento, do Estado de São Paulo, pelos doutores Ana Maria Cristina Rebello Pinto da Fonseca Martins e 
Marcio Hipolito, em parceria com o Laboratório de Higiene Zootécnica, da Faculdade de Zootecnia e Engenharia de alimentos da Universidade de São Paulo (USP/FZEA).

Para realização do estudo histopatológico, foram utilizados o fígado, o baço, o coração, uma porção do rim dorsal e fragmentos do intestino de larvas de tilápia do Nilo utilizadas nos processos de infecção experimental com Ranavirus, além das amostras teciduais correspondentes do grupo controle, coletados nos dias 18, 25, 38 e 60 pós-infecção (item 3.7, modelo 2).

Os órgãos foram fixados em formol a 10\% imediatamente após a eutanásia dos animais, e mantidos por um período de 48 horas. Posteriormente, foram transferidos para microtubos de $2 \mathrm{~mL}$ contendo álcool $70 \%$ para o procedimento de desidratação. Os processos de diafanização foram realizados utilizando xilol; e em seguida, foi realizada a inclusão dos tecidos em parafina. Cortes em espessura de $5 \mu \mathrm{m}$ foram obtidos nos processos de microtomia. Depois, as lâminas foram coradas com hematoxilina e eosina (H\&E) e analisadas através de microscopia óptica em diferentes lentes objetivas.

\subsection{EXTRAÇÃO DE DNA DE LARVAS E ALEVINOS DE TILÁPIA}

Aproximadamente 100mg de pool de tecidos (fígado, baço e rim dorsal) de larvas (vírus diluído nas águas dos tanques dos animais) e 100mg de fígado, baço e rim cranial de alevinos (vírus inoculado nos animais através de injeção intraperitoneal; coabitados com animais infectados) de tilápia do Nilo (Oreochromis niloticus) infectados experimentalmente com Ranavirus FV3-like, além das amostras teciduais correspondentes dos grupos controles, foram fragmentados e submetidos à extração de DNA utilizando o método do DNAzol ${ }^{\circledR}$ (Invitrogen, EUA), seguindo o protocolo do fabricante. As concentrações de DNA foram mensuradas através de espectrofotometria (DeNovix DS-11, EUA), segundo a razão de absorbância $\mathrm{A}_{260} / \mathrm{A}_{280}$. Para a utilização dos DNAs extraídos em PCR convencional, as concentrações padronizadas foram de $\leq 250 \mathrm{ng} / \mu \mathrm{L}$ e de $7,5 \mathrm{ng} / \mu \mathrm{L}$ para utilização em qPCR. Após as mensurações, as concentrações de DNA foram ajustadas aos respectivos protocolos utilizando água livre de nucleases. 


\subsection{PCR CONVENCIONAL PARA RANAVIRUS EM LARVAS E ALEVINOS DE TILÁPIA}

Para a identificação de animais positivos ao Ranavirus (prévia e pósinfecção experimental), foi realizada a reação em cadeia pela polimerase (PCR). O par de primers M151 e M152 foi utilizado para a amplificação de produto contendo aproximadamente 321 pares de base (pb) do gene MCP do gênero Ranavirus (OIE, 2017). O gene MCP é altamente conservado, o que o torna desejável para a identificação da presença de Ranavirus em animais infectados (JANCOVICH; STECKLER; WALTZEK, 2015).

Nas reações, foi utilizado o kit GoTaq ${ }^{\circledR}$ Colorless Master Mix (Promega, EUA), seguindo as recomendações do fabricante. Em síntese, $1,5 \mu \mathrm{L}$ de DNA extraído foi homogeneizado com $12,5 \mu \mathrm{L}$ de GoTaq ${ }^{\circledR}$ Colorless Master Mix 2X, 1,0 $\mu \mathrm{L}$ do primer senso específico (M151) a $10 \mu \mathrm{M}, 1,0 \mu \mathrm{L}$ do primer antissenso específico (M152) a $10 \mu \mathrm{M}$ e $9 \mu \mathrm{L}$ de água livre de nucleases (GE Healthcare, EUA), totalizando 25 $\mu$ L. Como controle negativo, foi utilizado alíquota de água livre de nucleases. Uma alíquota de DNA extraída de cultura celular (BF-2) infectada com Ranavirus na concentração de $10^{4}$ TCID $50 / m L$ foi utilizada como controle positivo da reação.

O protocolo de termociclagem empregado (Swift ${ }^{\circledR}$ MaxPro Thermal Cycler, Esco Technologies Inc., EUA) visando à amplificação de fragmento do gene MCP de Ranavirus compreendeu as seguintes fases: incubação a $94^{\circ} \mathrm{C}$ por $3 \mathrm{~min}$, seguido por 35 ciclos de $94^{\circ} \mathrm{C}$ por 30 segundos, $60^{\circ} \mathrm{C}$ por 30 segundos e $72^{\circ} \mathrm{C}$ por 1 min, com uma extensão final de $72^{\circ} \mathrm{C}$ por 5 minutos.

Os amplicons obtidos foram submetidos à eletroforese em gel de agarose a 1,5\% em tampão Tris-Acetato/EDTA (TAE 1X), num volume de $8 \mu \mathrm{L}$ de amostra, adicionado de um volume de $2 \mu \mathrm{L}$ de uma solução contendo $10 \mathrm{mM}$ Tris- $\mathrm{HCl}, 10 \mathrm{mM}$ EDTA, 0,3\% (w/v) de azul de bromofenol e 65\% (p/v) de sacarose, $\mathrm{pH}=7,5$, (BlueJuice ${ }^{\circledR}$ Gel Loading Buffer, Life Technologies, EUA). Na sequência, o gel foi submetido à coloração em solução de SYBR $^{\circledR}$ Gold Nucleic Acid Gel Stain (Life Technologies, EUA). Em seguida, o gel foi observado à luz ultravioleta, utilizando-se sistema de fotodocumentação L-Pix ST e software L-Pix Image (Loccus Biotecnologia, Brasil).

O tamanho dos amplicons foi determinado pela comparação ao padrão de migração eletroforética de um marcador molecular de 100pb (GE Healthcare, EUA). 


\subsection{QPCR PARA QUANTIFICAÇÃO ABSOLUTA DE RANAVIRUS EM AMOSTRAS DE LARVAS E DE ALEVINOS DE TILÁPIA}

\subsubsection{Produção de padrão para PCR quantitativo absoluto em tempo real}

O padrão baseado em sequência parcial de 495pb do gene MCP foi produzido a partir da amplificação de material genético extraído de cepa isolada de Ranavirus em cultura celular (BF-2), na concentração de $10^{4}$ TCID $50 / \mathrm{mL}$, através de PCR convencional, utilizando os primers RMCP-F e M152 (tabela 2).

O protocolo de termociclagem e análise do material amplificado foi o mesmo utilizado no item 3.13. Na sequência, as bandas presentes no gel foram cortadas com o auxílio de um bisturi e purificadas utilizando o kit illustra ${ }^{\circledR}$ GFX ${ }^{\circledR}$ PCR DNA and Gel Band Purification Kit (GE Healthcare, EUA), seguindo as instruções do fabricante. Posteriormente, os produtos de PCR purificados foram quantificados por espectrofotometria segundo a razão de absorbância A260/A280 (DeNovix DS-11, EUA).

Tabela 2 - Oligonucleotídeos iniciadores utilizados para construção de padrão para qPCR absoluto.

\begin{tabular}{cc}
\hline Primers & \multicolumn{1}{c}{ Sequências } \\
\hline RMCP-F e M152 & Forward: 5'-ATGACTTGTACAACGGGT-3’ \\
& Reverse: 5’-CGGGGCGGGGTTGATGAGAT-3’
\end{tabular}

Fonte: HUANG et al., 2011; OIE, 2017.

Imagem 3 - A. Comprimento médio do Gene MCP de Ranavirus. B. Construção de padrão para utilização em qPCR, a partir de amplificação de fragmento de 495pb do gene MCP de Ranavirus.

A
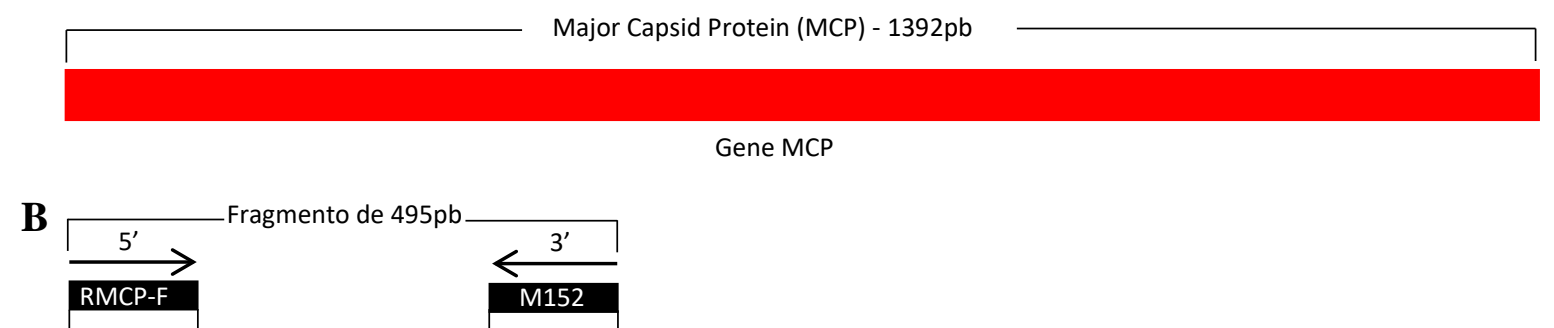

Região alvo - produção de padrão para qPCR

Fonte: Própria autoria. 


\subsubsection{Padronização e eficiência dos primers utilizados para quantificação absoluta através de PCR quantitativo em tempo real}

Para padronização da eficiência dos primers utilizados na qPCR (tabela 3), foram analisadas diferentes concentrações de primers e de DNA extraído de Ranavirus isolado em cultura de células BF-2 (tabela 4), sempre em duplicata.

Tabela 3 - Oligonucleotídeos iniciadores e probe utilizados no qPCR absoluto para Ranavirus.

\begin{tabular}{cc}
\hline Utilização & Sequências \\
\hline Primers e probe & Forward: 5'-AACGCCGACCGAAAACTG-3' \\
utilizados na qPCR & Reverse: 5'-GCTGCCAAGATGTCGGGTAA-3' \\
para quantificação de & Probe: 5'-CCGGCTTTCGGGC-3' \\
Ranavirus & \\
\hline
\end{tabular}

Fonte: ALLENDER; BUNICK; MITCHELL, 2013.

Tabela 4 - Concentrações de DNA e de primers utilizados para padronização das reações de qPCR.

Concentrações de DNA

$\begin{array}{lc}50 \mathrm{ng} & 100 \mathrm{nM} \\ 25 \mathrm{ng} & \\ 12.5 \mathrm{ng} & 300 \mathrm{nM} \\ 6,25 \mathrm{ng} & \\ 3,125 \mathrm{ng} & \\ 1,56 \mathrm{ng} & 400 \mathrm{nM}\end{array}$

Fonte: Própria autoria.

\subsubsection{Construção de curva padrão para quantificação absoluta em PCR quantitativo em tempo real}

Diluições seriadas na base de 10 foram realizadas para construção da curva padrão. A concentração do DNA viral foi definida através da massa em ng/ $\mu \mathrm{L}$. Desta forma, as diluições obtidas foram convertidas em número de cópias de alvo e empregadas como padrão para a quantificação das amostras em análise, sendo também aplicadas para a avaliação da sensibilidade de detecção da qPCR. O número de cópias foi determinado pela seguinte formula: Número de cópias $\mu \mathrm{L}=\underline{6.022 \times 10^{23} \text { (moléculas } / \mathrm{mole} \text { ) X DNA }(\mathrm{g} / \mu \mathrm{L})}$ número de pares de base $\mathrm{X} 660$ daltons 
Onde: $6.022 \times 10^{23}$ (moléculas/mole): número de Avogadro

660 daltons: peso médio de um par de bases

No total, seis diluições seriadas dos produtos purificados de PCR (item 3.14.1) foram utilizadas para confecção da curva padrão utilizando os primers e probe descritos na tabela 3, objetivando a amplificação de fragmento de 54pb do gene MCP de Ranavirus (imagem 4). As curvas padrão foram obtidas pela plotagem dos valores do threshold cycle $(C t)$ no eixo-Y e o log da concentração (cópias/ $\mu \mathrm{L}$ ) dos produtos purificados de PCR no eixo-X. Posteriormente, a curva padrão foi analisada por regressão linear.

Imagem 4 - Região alvo de 54pb para construção de curva padrão, rastreamento e quantificação de Ranavirus através de qPCR absoluto.

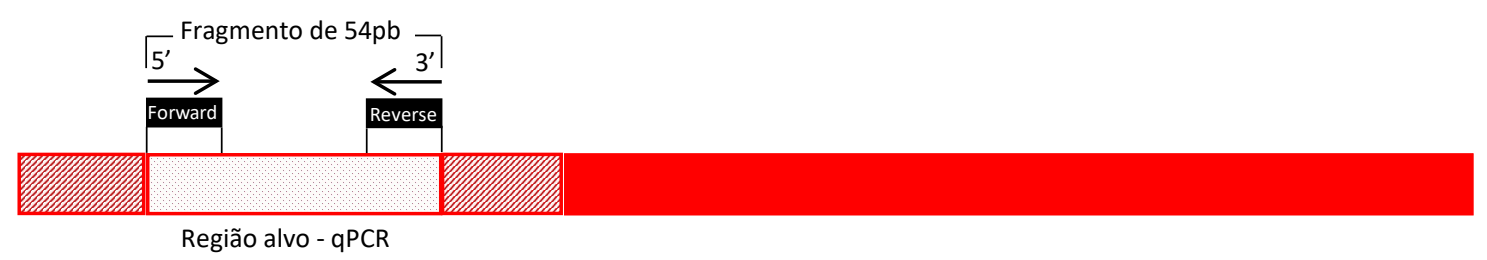

Fonte: Própria autoria.

As sequências de oligonucleotídeos utilizadas foram analisadas em banco mundial de genes (GenBank), empregando o algoritmo BLAST, para assegurar que eram específicas para Ranavirus (http://www.ncbi.nlm.nih.gov/BLAST), demonstrando ter alta especificidade para as estirpes virais já identificadas mundialmente.

\subsubsection{Eficiência de amplificação}

A curva-padrão foi utilizada para calcular o coeficiente angular da reta (slope), composta pelos pontos da curva. Este dado foi utilizado para calcular a eficiência da amplificação (E). Uma alta eficiência está associada a uma inclinação de aproximadamente 3,32 para cada diluição de 10 do alvo (TOO, 2003). Slope de $-3,3$ relaciona-se a uma eficiência de 100\% indicando que o número de moléculas amplificadas dobra a cada ciclo da PCR quantitativa (KUBISTA et al., 2006).

O valor de inclinação da reta obtido pela regressão linear de cada curva padrão gerada foi utilizado para se calcular a eficiência de amplificação $(E)$ da qPCR de acordo com a seguinte equação: $E=10^{(-1 / \text { slope })}-1$. 


\subsubsection{Limiar de deteç̧ão da qPCR}

O limiar de detecção da qPCR foi definido através da determinação dos Cts produzidos por cada diluição e da curva padrão. As seis diluições utilizadas apresentaram Cts entre os ciclos 11,52 a 29,38, e foram utilizadas como referência para a quantificação da carga viral em animais infectados experimentalmente com Ranavirus.

\subsubsection{Quantificação da carga viral através de PCR quantitativo absoluto em tempo real}

Após as padronizações, a carga viral contida em diferentes tecidos dos animais (larvas e alevinos de tilápia) sob experimentação foi determinada através da técnica de PCR quantitativo absoluto em tempo real (qPCR), utilizando-se o sistema TaqMan ${ }^{\circledR}$ MGB Probes (Invitrogen, EUA). Os primers utilizados nas reações (tabela 3) tiveram como alvo a amplificação de produto com 54pb do gene MCP de Ranavirus (imagem 4). Os reagentes utilizados para a amplificação do fragmento através de qPCR estão descritos no quadro 1.

Quadro 1 - Reagentes utilizados para amplificação de fragmento do gene MCP de Ranavirus através de qPCR.

\begin{tabular}{|l|l|}
\hline Reagentes & Volume \\
\hline Platinum ${ }^{\circledR}$ quantitative PCR SuperMix-UDG & $12,5 \mu \mathrm{L}$ \\
\hline ROX Reference Dye (diluído 1:10) & $0,5 \mu \mathrm{L}$ \\
\hline Água DEPC & $7,75 \mu \mathrm{L}$ \\
\hline Primer F a $10 \mu \mathrm{M}$ & $1 \mu \mathrm{L}$ \\
\hline Primer R a $10 \mu \mathrm{M}$ & $1 \mu \mathrm{L}$ \\
\hline Probe a $10 \mu \mathrm{M}$ & $0,25 \mu \mathrm{L}$ \\
\hline DNA a $7,5 \mathrm{ng} / \mu \mathrm{L}$ & $2 \mu \mathrm{L}$ \\
\hline Volume total & $25 \mu \mathrm{L}$ \\
\hline
\end{tabular}

Fonte: Adaptado de ALLENDER; BUNICK; MITCHELL, 2013.

As amplificações de fragmento de DNA foram realizadas em duplicata (inclusive controles positivos e negativos) utilizando MicroAmp ${ }^{\circledR}$ Optical 8-Cap Strips e MicroAmp ${ }^{\circledR}$ Fast 8-Tube Strip (Applied Biosystems, Reino Unido) em um aparelho Applied Biosystems 7500 Fast Real-Time PCR System (Applied Biosystems, Reino Unido). 
O protocolo de termociclagem empregado, visando à amplificação de fragmento genômico viral de Ranavirus, compreendeu: incubação a $95^{\circ} \mathrm{C}$ por 10 min para desnaturação inicial e ativação da DNA polimerase, e, em seguida, 40 ciclos de $95^{\circ} \mathrm{C}$ por 15 segundos e $60^{\circ} \mathrm{C}$ por 1 minuto. O controle positivo (DNA extraído de cepa isolada de Ranavirus em cultura de células BF-2) foi incluído em cada reação para assegurar a sensibilidade e especificidade da qPCR; e o controle negativo (água DEPC) foi acrescentado às reações para excluir a possibilidade de contaminação com o DNA em análise.

\subsection{IMUNO-HISTOQUÍMICA EM LARVAS DE TILÁPIA}

As larvas de tilápia do Nilo que foram experimentalmente infectadas com Ranavirus na concentração de $10^{4} \mathrm{TCID}_{50} / \mathrm{mL}$, foram utilizadas para a realização de exames imuno-histoquímicos (IHC), realizados no Cornell Wildlife Health Lab, Animal Health Diagnostic Center, College of Veterinary Medicine, Cornell University, Ithaca, New York, EUA, pela equipe da Dra. María J. Forzán em parceria com o Laboratório de Higiene Zootécnica, da Faculdade de Zootecnia e Engenharia de Alimentos da Universidade de São Paulo (USP/FZEA). Os animais foram enviados emblocados em parafina seguindo as normas vigentes dos dois países (Brasil e Estados Unidos).

Para a realização da técnica, tecidos integrados em parafina e fixados em formalina, foram corados imuno-histoquimicamente para se detectar a presença de antígeno de Ranavirus spp. utilizando anticorpo de coelho policlonal contra membro do gênero Ranavirus, Epizootic haematopoietic necrosis virus (EHNV) (REDDACLIFF; WHITTINGTON, 1996). Os anticorpos anti-EHNV são conhecidos por reagir de forma cruzada com outros vírus do gênero (ARIEL et al., 2010; HYATT et al., 2000). Um sistema de coloração automatizado Leica BOND-MAX (Leica Microsystems, EUA) foi utilizado para execução de protocolo previamente validado para o anti-EHNV de coelho, purificado por afinidade (Lote N. ${ }^{\circ}$ M708, OIE Reference Laboratory for EHN Virus, University of Sydney).

O material foi desparafinado na Cornell University através de imersão em banhos de xilol (2x durante 5 min e 1x durante $10 \mathrm{~min}$ ), hidratado em banhos sequenciais de etanol 100\%, 95\% e 70\% (5 min cada etapa) e lavado em água destilada (1 min); posteriormente, foram realizados cortes de $5 \mu \mathrm{m}$ de espessura nos tecidos para identificação dos melhores pontos alvo; em seguida, os cortes foram fixados em lâminas para microscopia. 
Recuperação de epítopo induzido por calor (HIER) com solução de recuperação de epítopos de ligação 1 foi aplicado durante 30 min no material analisado (Leica, Cat \# AR9961).

O anticorpo anti-EHNV de coelho diluído a 1:3000 foi aplicado nas lâminas durante 15 min; em seguida, um polímero (anticorpo secundário, poli - HRP - IgG anticoelho, Leica, Cat \# DS9390) foi aplicado durante $10 \mathrm{~min}$. Posteriormente, Leica Bond Polymer Refine Red Detection foi aplicado por 15 min (Leica, Cat \# DS9390). Após estes passos, o tecido foi contrastado com hematoxilina, aplicada durante 5 min (Leica, Cat \# DS9390). As lavagens entre os passos foram realizadas utilizando uma solução padrão da Leica, de acordo com as especificações do fabricante. Controles positivo e negativo conhecidos foram executados juntos com os slides de teste. As lâminas foram analisadas em microscópio Olympus BX51 em todas as objetivas. A contagem das células imunomarcadas foi realizada a partir da captura de cinco campos, no aumento de 40 vezes, com câmera Olympus DP12 (software cellSens Standard 1.5, Olympus Corporation, EUA), as imagens foram analisadas com o software Image-Pro Plus versão 7.0 (Media Cybernetics, EUA).

Um tecido foi considerado positivo se uma coloração forte e distinta utilizando o anticorpo anti-EHNV (Ranavirus spp.) estivesse presente no citoplasma de uma ou mais células e a coloração de fundo estivesse ausente ou claramente distinta da coloração específica verdadeira.

\subsection{HIBRIDIZAÇÃO IN SITU EM LARVAS DE TILÁPIA}

As análises de hibridização in situ (ISH) foram realizadas no Cornell Wildlife Health Lab, Animal Health Diagnostic Center, College of Veterinary Medicine, Cornell University, Ithaca, New York, EUA, pela equipe da Dra. María J. Forzán em parceria com o Laboratório de Higiene Zootécnica, da Faculdade de Zootecnia e Engenharia de Alimentos da Universidade de São Paulo (USP/FZEA), utilizando os mesmos animais ensaiados imunohistoquimicamente, item 3.15.

As amostras em parafina foram cortadas em espessura de $5 \mu \mathrm{m}$ e montadas sobre lâminas de microscopia; posteriormente, as secções foram aquecidas a $56^{\circ} \mathrm{C}$ durante 30 min, desparafinadas em xilol e subsequentemente reidratadas em PBS (pH 7,4 e 0,01M) durante 5 minutos. A desproteinização foi realizada em HCL $0,2 \mathrm{~N}$, durante $20 \mathrm{~min}$ a $37^{\circ} \mathrm{C}$, com

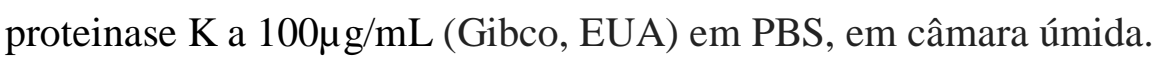


Após a digestão, os tecidos foram fixados em 0,4\% de formaldeído frio em PBS durante 5 minutos. Após enxaguar duas vezes com citrato de sódio salino 2x (SSC), as lâminas foram deixadas durante 60 min a $42^{\circ} \mathrm{C}$ em câmara úmida em tampão de hibridação padrão, que consistiu em 4x SSC com 50\% de formamida deionizada, 1x Denhardt's, 5\% de sulfato de dextrano e $0,5 \mathrm{mg} \mathrm{mL}^{-1}$ de DNA de esperma de salmão desnaturado. A hibridação foi realizada durante a noite a $42^{\circ} \mathrm{C}$. A sonda marcada com digoxigenina (2ng $\mu \mathrm{L}^{-1}$ no tampão padrão de hibridação) e o DNA dos tecidos nas lâminas (os tecidos foram cobertos com o tampão de hibridação padrão) foram aquecidos durante 10 min a $95^{\circ} \mathrm{C}$ em bloco de aquecimento, e resfriados em gelo durante 1 minuto.

Posteriormente, foi acrescentado $1 \mathrm{~mL}$ de tampão de hibridação padrão fresco contendo aproximadamente 50ng da sonda marcada com digoxigenina; a hibridação foi realizada a $42^{\circ} \mathrm{C}$ durante a noite em câmara úmida. Posteriormente, os cortes foram lavados completamente da seguinte forma: uma vez em 2x SSC durante 15 min em temperatura ambiente (TA), uma vez em 1x SSC durante 5 min em TA, duas vezes em 0,5X SSC durante 15 min a $42^{\circ} \mathrm{C}$, duas vezes em $0,1 \mathrm{X}$ SSC durante 15 min a $42^{\circ} \mathrm{C}$ e uma vez em tampão ácido maleico (100mM de ácido maleico e 150mM de $\mathrm{NaCl}, \mathrm{pH}$ 7,5) durante 5 min em TA.

Para a detecção da hibridização, as secções foram incubadas com antidigoxigenin conjugado com fosfatase alcalina (Roche Molecular Biochemicals, EUA) diluído 1:500 em Tris-HCl 0,1M (pH 7,4), 0,1 SM-NaCl, com 1\% de reagente de bloqueio (Roche Molecular Biochemicals, EUA). Após três lavagens em tampão de ácido maleico, o substrato constituído por Nitro-blue tetrazolium (NBT) e 5-bromocresyl-3-indolyl-phosphate (BCIP) foi aplicado em camadas sobre as seções. A coloração foi deixada desenvolver durante 3 horas em ambiente escuro; a reação foi interrompida imergindo as lâminas em tampão de ácido tris-etilenodiaminotetracético (Tris-HCl 10mM e EDTA 1mM, pH 8,0). As lâminas foram então lavadas com água destilada durante 1 min e depois desidratadas em 95\% de álcool durante $1 \mathrm{~min}, 100 \%$ de álcool durante 1 min e depois mergulhadas em xilol absoluto. Em seguida, as lâminas foram montadas com meio de montagem Eukitt (Electron Microscopy Sciences, EUA) e analisadas. 


\subsection{SEQUENCIAMENTO DO GENOMA VIRAL DE ESTIRPE DE RANAVIRUS}

O sequenciamento molecular (Next Generation - NGS) do genoma de estirpe de Ranavirus FV3-like utilizada nos processos de infecções experimentais foi realizado em plataforma Illumina $^{\circledR}$ Sequencing (Illumina, EUA) pela empresa BPI Biotecnologia Pesquisa e Inovação (Botucatu-SP).

\subsubsection{Avaliação de qualidade da amostra}

DNA extraído de Ranavirus, isolado em cultura de células BF-2 (bluegill fry ATCC ${ }^{\circledR}$ CCL-91 ${ }^{\mathrm{TM}}$ ), foi encaminhado para a empresa BPI, onde passou por análise de qualidade através de eletroforese em gel de agarose a 2\% e quantificação por fluorescência através do Qubit ${ }^{\circledR} 2.0$ Fluorometer (Thermo Fisher Scientific, EUA).

\subsubsection{Purificação do DNA total}

O DNA foi submetido a etapas de purificação utilizando beads magnéticas Agencourt $^{\circledR}$ AMPure $^{\circledR}$ XP (Beckman Coulter, EUA) e foi novamente quantificado por fluorescência através do Qubit ${ }^{\circledR} 2.0$ Fluorometer (Thermo Fisher Scientific, EUA).

\subsubsection{Preparo da biblioteca utilizando Nextera ${ }^{\circledR}$ XT DNA Library Prep Kit (Illumina, EUA)}

\subsubsection{Tagmentação do DNA}

O DNA genômico foi submetido ao protocolo do kit Nextera ${ }^{\circledR}$ XT DNA Library Sample Preparation (Illumina, EUA). Nesta etapa, a ação de enzimas específicas tagmentam o DNA adicionando, de forma simultânea, sequências adaptadoras (tags). Foram adicionados $5 \mu \mathrm{L}$ de DNA genômico a $0,2 \mathrm{ng} / \mu \mathrm{L}, 10 \mu \mathrm{L}$ de tampão TD e $5 \mu \mathrm{L}$ da enzima TD (enzima de tagmentação do DNA). A reação foi transferida para um termociclador Veriti ${ }^{\circledR}$ Thermal Cycler (Applied Biosystems, EUA) onde foi submetida à incubação a $55^{\circ} \mathrm{C}$ durante 5 minutos. 


\subsubsection{Amplificação do DNA e indexação}

Nesta etapa o DNA tagmentado é amplificado e submetido à inserção de indexadores nos adaptadores comuns, que são necessários para a geração de clusters e sequenciamento das amostras. A reação de PCR foi realizada seguindo o protocolo do kit Nextera XT Index (Illumina, EUA). O programa de amplificação consistiu de: incubações à $72^{\circ} \mathrm{C}$ por 3 min e $95^{\circ} \mathrm{C}$ por 30 segundos, seguido de 12 ciclos de $95^{\circ} \mathrm{C}$ por 10 segundos, $55^{\circ} \mathrm{C}$ por 30 segundos e $72^{\circ} \mathrm{C}$ por 30 segundos com incubação final de $72^{\circ} \mathrm{C}$ por 5 minutos. As reações de amplificação foram conduzidas em termociclador Veriti ${ }^{\circledR}$ Thermal Cycler (Applied Biosystems, EUA).

\subsubsection{Purificação e quantificação da biblioteca}

As bibliotecas geradas foram submetidas a etapas de purificação utilizando beads magnéticas Agencourt ${ }^{\circledR}$ AMPure $^{\circledR}$ XP (Beckman Coulter, EUA), para remoção de fragmentos muito pequenos da população total de moléculas e restos de primers. Posteriormente, foi realizada a quantificação pela metodologia de PCR em tempo real no termociclador QuantStudio 3 Real-Time PCR System (Applied Biosystems, EUA), utilizando Kit KAPA-KK4824 (Library Quantification Kit - Illumina ${ }^{\circledR} /$ Universal, EUA), de acordo com o protocolo do fabricante. Então, foi gerado um pool equimolar de DNA através da normalização de todas as amostras a $4 \mathrm{nM}$ para a realização do sequenciamento, o qual foi conduzido utilizando-se o sistema Illumina ${ }^{\circledR}$ MiSeq de sequenciamento de nova geração (Illumina, EUA).

\subsubsection{Bioinformática}

A montagem do genoma viral foi realizada com o programa A5-miseq, que contém as instruções para limpeza das amostras e assembly das sequencias. Para a identificação das fases de leitura abertas (Open Reading Frame) foi utilizado o programa ORFfinder (https://www.ncbi.nlm.nih.gov/orffinder/), com posterior comparação com sequências de banco de dados utilizando o programa blastx. 


\subsection{GENOMAS DE RANAVIRUS DE REFERÊNCIA}

Para realização da caracterização filogenética, análises de identidade e detecção de recombinação do genoma em análise, sequências genômicas de 19 membros da família Iridoviridae representando todas as espécies de Ranavirus que possuem o genoma disponível, foram recuperadas do GenBank (tabela 5).

Tabela 5 - Sequências genômicas de Ranavirus utilizadas para reconstrução filogenética, análises de identidade e detecção de recombinação com indicação da espécie viral, hospedeiro, origem e respectivos códigos de acesso no GenBank.

\begin{tabular}{llll}
\hline Espécie viral & Hospedeiro & Origem & Cód. de acesso no GenBank \\
\hline EHNV-like & Perca fluviatilis & Austrália & FJ433873 \\
EHNV-like & Perca fluviatilis & Austrália & NC_028461 \\
ECV-like & Ameiurus nebulosus & Hungria & KT989885 \\
ECV-like & Ameiurus nebulosus & Hungria & KT989884 \\
ATV-like & Ambystoma tigrinum & Estados Unidos & KR075874 \\
ATV-like & Ambystoma tigrinum & Estados Unidos & KR075886 \\
ATV-like & Ambystoma mexicanum & Estados Unidos & KR075872 \\
CMTV-like & Testudo kleinmanni & Alemanha & KP266743 \\
CMTV-like & Sander lucioperca & Finlândia & KX574341 \\
CMTV-like & Pelophylax klepton esculentus & Dinamarca & MF538627 \\
CMTV-like & Pelophylax ridibundus & Holanda & MF004271 \\
BIV-like & Limnodynastes ornatos & Austrália & KX185156 \\
FV3-like & Hoplobatrachus tigerinus & China & AF389451 \\
FV3-like & Rana grylio & China & JQ654586 \\
FV3-like & Oophaga pumilio & Holanda & MF360246 \\
FV3-like & Frog (espécie não informada) & Estados Unidos & KJ175144 \\
FV3-like & Lithobates pipiens & Estados Unidos & AY548484 \\
SGIV-like & Não informado & Não informada & AY521625 \\
SGIV-like & Não informado & Não informada & NC 006549 \\
\hline
\end{tabular}

Legenda: EHNV- Epizootic haematopoietic necrosis virus; ECV - European catfish virus; ATV Ambystoma tigrinum virus; CMTV - Common midwife toad virus; BIV - Bohle iridovirus; FV3 - Frog virus 3; SGIV - Singapore grouper iridovirus.

Fonte: Própria autoria.

\subsection{ALINHAMENTO DE SEQUENNCIAS NUCLEOTÍDICAS}

As sequências nucleotídicas genômicas foram alinhadas através do software MAFFT, versão 7, com configurações em 'default' (KATOH; ROZEWICKI; YAMADA, 2017). 


\subsection{ANÁLISE FILOGENÉTICA}

A caracterização filogenética da sequência genômica em análise foi realizada através do método Neighbor-Joining (NJ), utilizando-se para tanto o modelo de substituição Kimura 2-parameter com suporte nodal de bootstrap para 1000 pseudo-réplicas através do programa MEGA 6.0 (TAMURA et al., 2013).

\subsection{ANÁLISES DE IDENTIDADE}

As pontuações de identidade de pares, utilizando o genoma completo, e em paralelo, para o gene Major Capsid Protein (MCP), de Ranavirus foram calculadas utilizando o software Sequence Demarcation Tool (SDT) (MUHIRE; VARSANI; MARTIN, 2014), com configurações em 'default'. O gene MCP é altamente conservado entre as diferentes espécies de Ranavirus, o que o torna adequado para o diagnóstico presuntivo em animais infectados através da reação de PCR convencional (JANCOVICH; STECKLER; WALTZEK, 2015).

\subsection{ANÁLISE DE RECOMBINAÇÃO}

A análise de recombinação entre o genoma em estudo e genomas de Ranavirus FV3-like (> 90\% de identidade) de referência (tabela 5), foi realizada utilizando o software RDP4 versão 4.95 em configurações padrão, com valor de $p<0,05$ (MARTIN et al., 2015).

\subsection{ANÁLISES ESTATÍSTICAS}

Foram realizadas análises para verificação de significâncias estatísticas relacionando concentração viral utilizada nos processos de infecção experimental, dias pósinfecção e interações entre estes dois parâmetros. Para tanto, os parâmetros envolvidos foram: índices hepato-somáticos (IHS) e espleno-somáticos (IES), atividades das enzimas ALT (alanina aminotransferase) e AST (aspartato aminotransferase), leucócitos, diferenciando-os em neutrófilos, eosinófilos, basófilos, linfócitos e monócitos, contagem total de eritrócitos, dosagem de hemoglobina, determinação de hematócrito e índices hematimétricos absolutos. 
Os dados foram analisados em um delineamento inteiramente casualizado utilizando-se o procedimento MIXED do SAS versão 9.4, sendo anteriormente verificada a normalidade dos resíduos pelo teste de Shapiro-Wilk (SHAPIRO; WILK, 1965) e a homogeneidade das variâncias comparada pelo teste de Levene (1960). Quando não responderam aos princípios de distribuição normal, os dados foram submetidos a identificação de outliers e transformações em logaritmo. As variáveis que não responderam a normalidade dos dados mesmo após estes procedimentos, foram submetidas à estatística de Kruskal-Wallis (KRUSKAL; WALLIS, 1952), seguido do teste de qui-quadrado utilizado para encontrar diferenças estatísticas.

Havendo normalidade, os dados foram analisados pelo método dos quadrados mínimos segundo o procedimento LSMEANS do programa computacional SAS versão 9.4. O modelo contemplou como causas de variação o efeito fixo de concentração, dia e suas interações. Os graus de liberdade e testes foram ajustados usando a opção KenwardRoger (KENWARD; ROGER, 1997). A significância foi declarada à $p \leq 0,05$. Quando a significância da interação entre os efeitos principais foi $p \leq 0,10$, a interação foi decomposta e os efeitos dos tratamentos foram analisados usando a opção SLICE de PROC MIXED.

\subsection{TRATAMENTO DA ÁGUA PÓS-EXPERIMENTOS}

Toda água utilizada nos tanques dos animais pós-experimento, foi tratada com Virkon (Inovet, Brasil), seguindo as instruções do fabricante, antes de ser descartada. 


\section{RESULTADOS}

\subsection{OBTENÇÃO DOS ALEVINOS}

Foram obtidos aproximadamente 140 alevinos $( \pm 25 \mathrm{~g})$ e 360 larvas $( \pm 1,5 \mathrm{~g})$ de tilápia do Nilo (Oreochromis niloticus), sem distinção sexual. Os animais foram doados pela Piscicultura Polettini, localizada em Mogi Mirim - SP, pelo sócio proprietário Cesar Polettini. Os animais foram transportados para o local de destino (Universidade de São Paulo - USP/FZEA em Pirassununga - SP) em embalagens próprias para o transporte de peixes, com inserção de gás oxigênio para melhor manutenção dos animais. Após o acondicionamento no local de destino, três larvas e três alevinos foram selecionados ao acaso, insensibilizados com benzocaína, na proporção de 200mg para cada litro de água e eutanasiados através de concussão cerebral seguido de perfuração craniana; em seguida, foram extraídos o baço, o fígado e uma porção do rim dorsal dos animais. Posteriormente, os tecidos foram submetidos à extração de DNA conforme item 3.12, e análise para identificação de animais previamente positivos ao Ranavirus, através de PCR convencional, como consta no item 3.13. Os resultados para infecção prévia por Ranavirus foram negativos.

\subsection{TANQUES E MANUTENÇÃO DOS ANIMAIS}

Os animais foram condicionados exatamente como consta nos itens 3.3 e 3.4. Durante o período de adaptação (11 dias no caso das larvas e 30 dias no caso dos alevinos) uma média de 2 a 4 animais mortos por aquário foi observada. A elucidação sugerida para esta causa é devido à elevação na concentração de cortisol no sangue dos animais durante o transporte e período inicial de confinamento dos peixes. Níveis excessivos deste homônimo suprimem a resposta imunológica dos animais e a resposta inflamatória, beneficiando o aparecimento de eventuais infecções bacterianas oportunistas. Adicionalmente, o desequilíbrio do cortisol provoca aumento da permeabilidade das membranas branquiais, levando os peixes a um desequilíbrio osmorregulatório, devido à excessiva entrada de água e perda de minerais (em especial o sódio e o cloreto) através das brânquias. Sendo assim, os peixes podem morrer mesmo apresentando aspecto sadio no período pós-transporte (WURTS, 1995; KUBITZA, 1997). 


\subsection{INFECÇÃO EXPERIMENTAL E VIAS DE INFECÇÃO}

Os procedimentos e vias de infecção experimental utilizados ocorreram exatamente como consta nos itens 3.5 e 3.6.

Imagem 5 - Infecção experimental com Ranavirus em tilápias do Nilo, através de injeção intraperitoneal de $0,1 \mathrm{~mL}$.

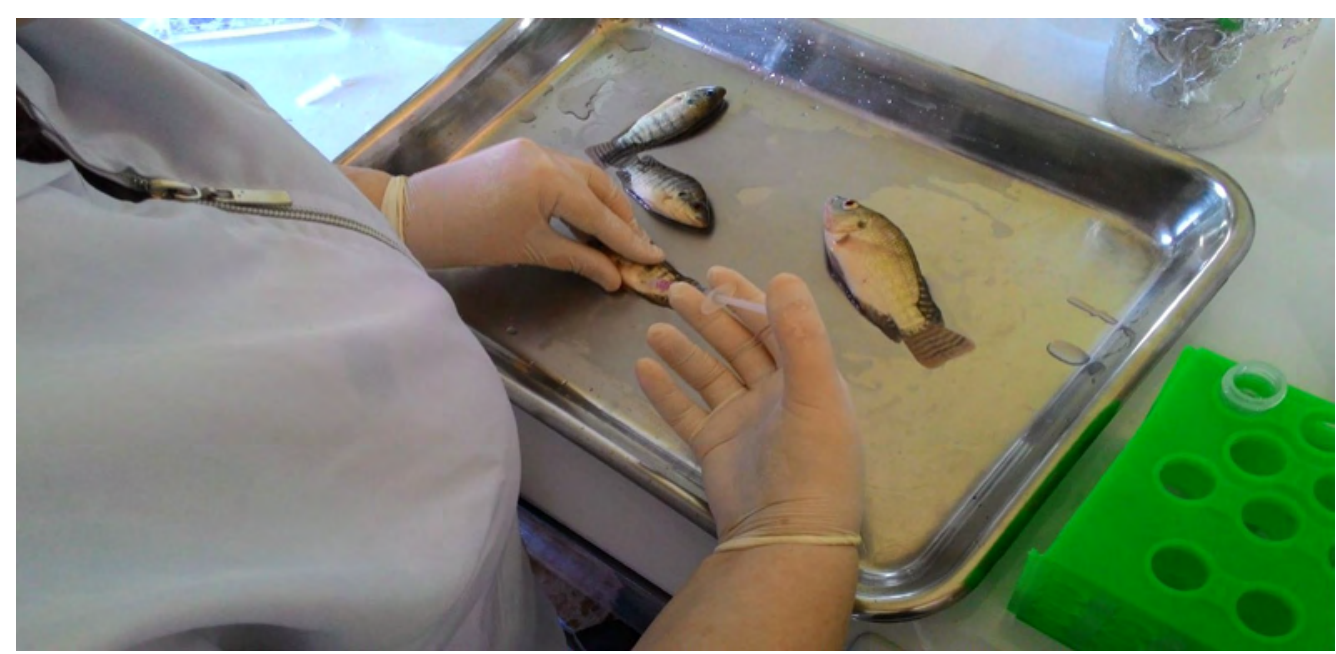

Fonte: Própria autoria.

Apenas dois alevinos foram encontrados mortos no período pós-infecção. Um dos animais um dia depois, e o outro, três dias depois de ser infectado experimentalmente com Ranavirus FV3-like, possivelmente devido ao estresse causado no processo de infecção. Ambos os animais haviam sido inoculados na concentração de $10^{2}$ TCID $50 / \mathrm{mL}$. No caso das larvas, nenhum animal foi encontrado morto após ser desafiado com o vírus.

\subsection{COLETA DE ANIMAIS PARA AS ANÁLISES PÓS-INFECÇÃO}

Os procedimentos de coleta de animais para as análises pós-infecção ocorreram exatamente como consta no item 3.7.

Alguns alevinos de tilápia apresentaram alterações macroscópicas internas e externas anormais dentro do período de 60 dias pós-infecção, estas alterações podem ser observadas nas imagens 6-10. Em relação às larvas, nenhuma alteração macroscópica interna ou externa foi observada nos animais no período pós-infecção. 
Imagem 6 - Animal com o globo ocular colapsado e com edema (possível hemorragia), 12 dias pósinfecção, na concentração de $10^{3} \mathrm{TCID}_{50} / \mathrm{mL}$.

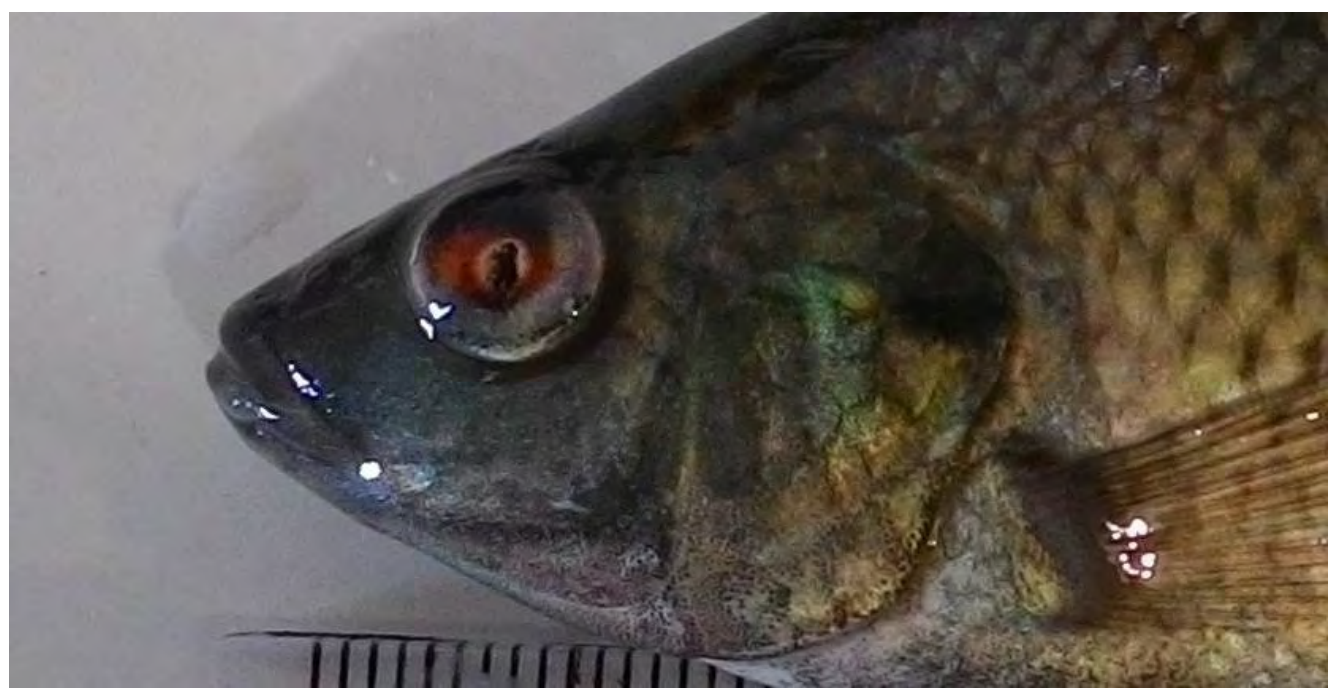

Fonte: Própria autoria.

Imagem 7 - Manchas brancas e palidez no fígado dos animais, a partir de 38 dias pós-infecção, em todas as concentrações virais utilizadas, indicando possível necrose hepática.

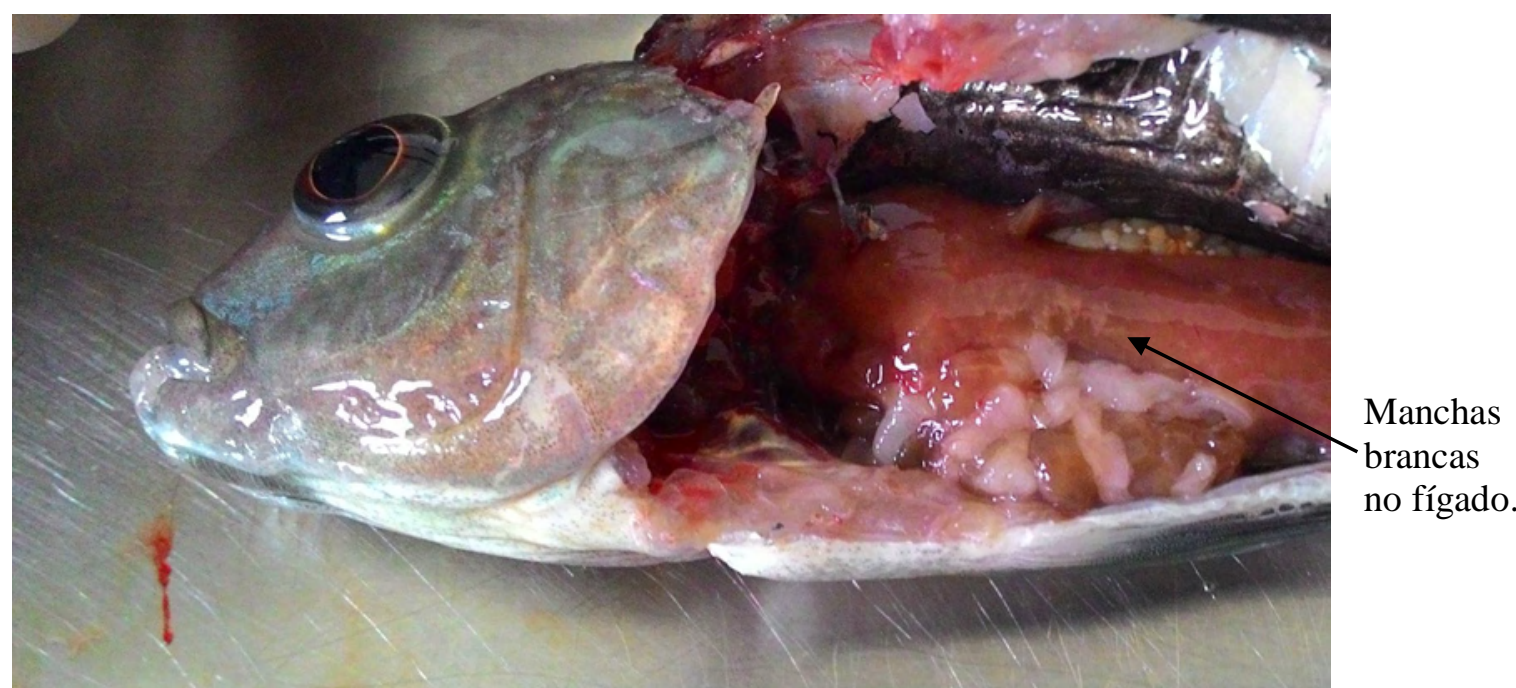

Fonte: Própria autoria. 
Imagem 8 - Eritema na região submandibular, pigmentação escura e estrias avermelhadas na superfície dos peixes, a partir de 25 dias pós-infecção, nas concentrações virais de $10^{2}, 10^{3}$ e $10^{4}$ $\mathrm{TCID}_{50} / \mathrm{mL}$.

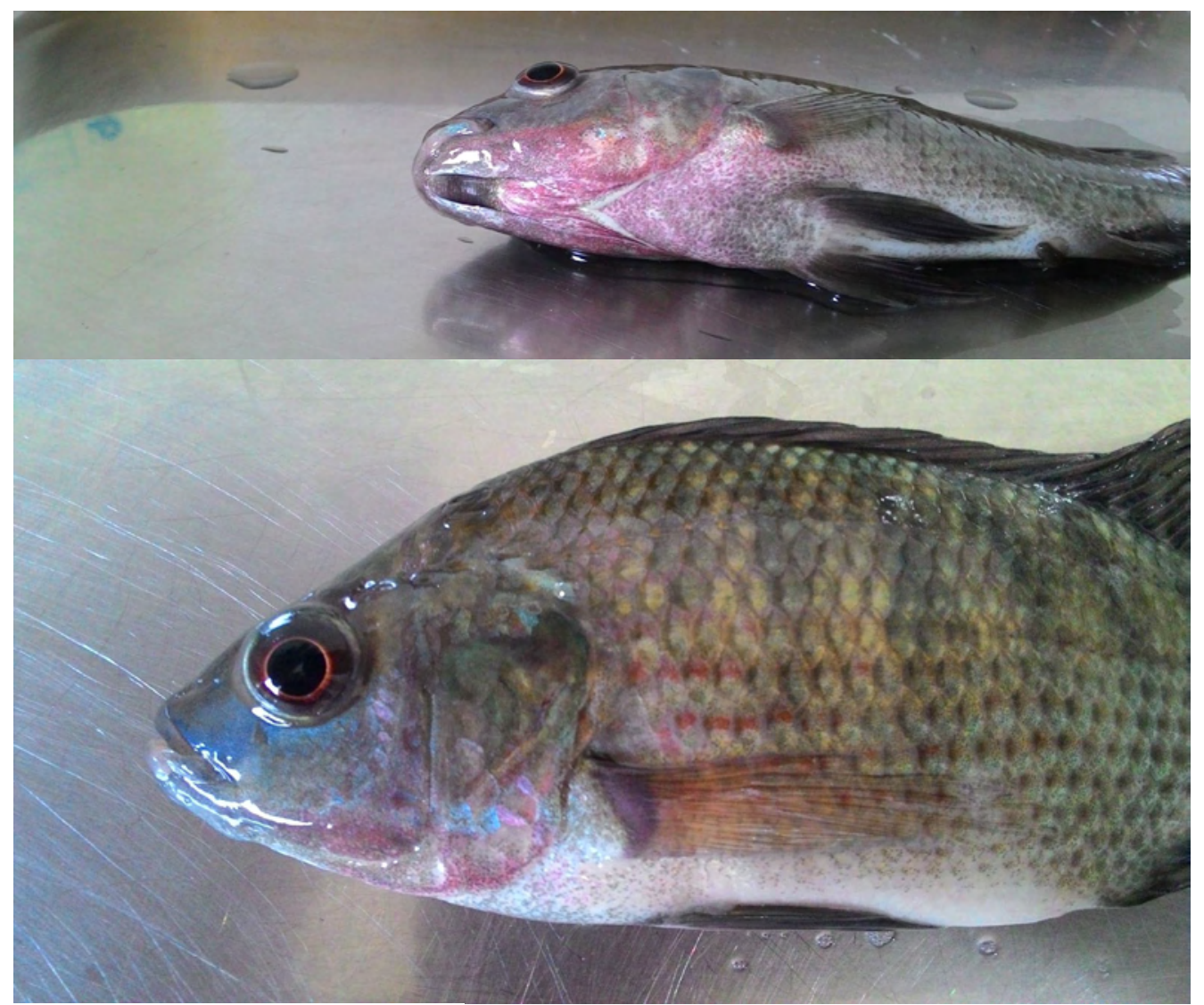

Fonte: Própria autoria.

Imagem 9 - Diferentes graus de exoftalmia, a partir de 25 dias pós-infecção, em todas as concentrações virais utilizadas.

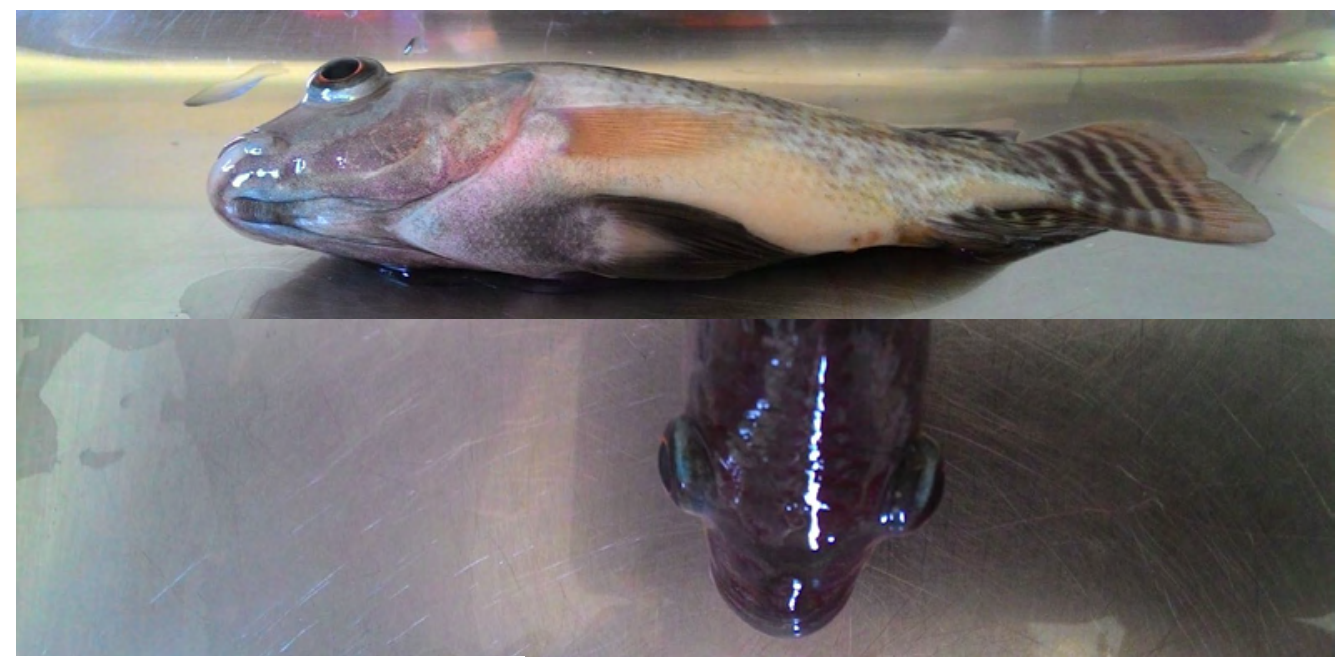

Fonte: Própria autoria. 
Imagem 10 - Bílis amarelada em $1 / 4$ dos peixes infectados, nas concentrações de $10^{3}$ e $10^{4}$ TCID $50 / \mathrm{mL}$, a partir do dia 25 pós-infecção.

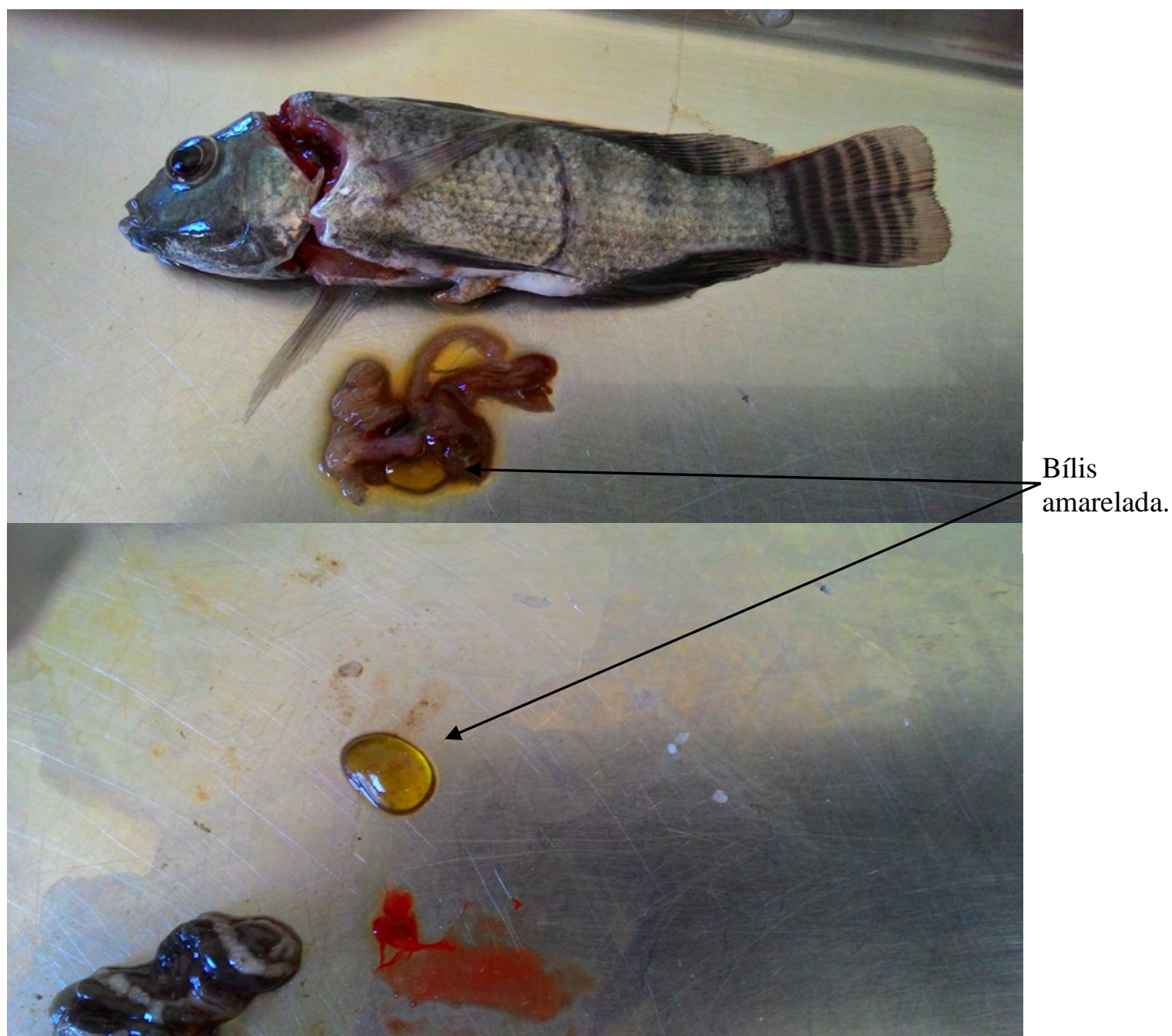

Fonte: Própria autoria.

\subsection{ANÁLISES HEMATOLÓGICAS EM ALEVINOS DE TILÁPIA}

As alterações sanguíneas mais significativas foram um aumento expressivo na quantidade de eritrócitos lisados (imagem 20), de duas a três vezes maior a partir do quarto dia de infecção em comparação ao controle, e o expressivo aparecimento de hemácias jovens a partir $12^{\circ}$ dia pós-infecção, indicando uma possível reposição de células perdidas. Diferenciação acentuada no tamanho e coloração das hemácias, a partir do $12^{\circ}$ dia pósinfecção até o último dia de coleta ( $60^{\circ}$ dia pós-infecção) foi observado (imagem 13). Além disso, houve significância estatística relacionada ao volume corpuscular médio (VCM) para o efeito da concentração viral utilizada nas infecções experimentais $(p<0,01)$ e dias pósinfeção $(p<0,01)$. Porém para a interação concentração/dia o valor de $p$ foi $=0,20$. Houve 
também significância estatística relacionada a hemoglobina corpuscular média (HCM) para a concentração viral utilizada $(p<0,01)$ e dias pós-infecção $(p<0,05)$. Porém, em relação ao efeito da interação concentração/dia, não houve significância estatística $(p>0,05)$. Os valores de proteína plasmática total (PPT) apresentaram significância estatística para o efeito dos dias pós-infecção $(p<0,05)$.

Outra característica expressiva foi o aparecimento de linfócitos reativos a partir do quarto dia de infecção em animais experimentados nas concentrações de $10^{2}, 10^{3}$ e $10^{4}$, representando resposta a um antígeno. Os animais infectados na dosagem de $10^{1}$ $\mathrm{TCID}_{50} / \mathrm{mL}$ apresentaram linfócitos reativos apenas no último dia de coleta, o que corresponde a exatos 60 dias pós inoculação com Ranavirus FV3-like, podendo indicar um início de infecção tardia devido à menor concentração de vírus inoculado.

\subsection{ESFREGAÇO SANGUÍNEO DE ALEVINOS DE TILÁPIA INFECTADOS EXPERIMENTALMENTE COM RANAVIRUS}

Imagem 11 - Eritrócitos maduros e trombócitos (setas). Lente objetiva de 100X.

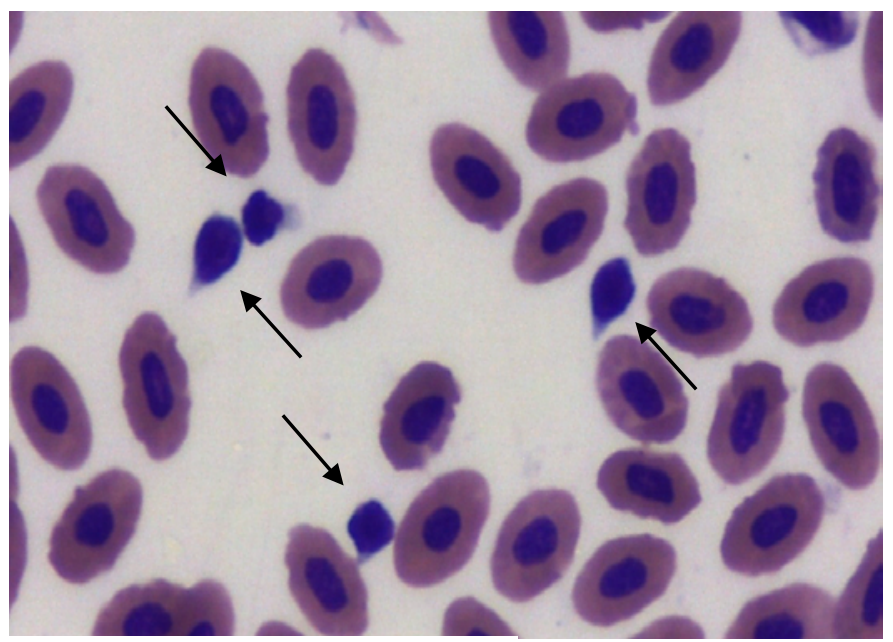

Fonte: Própria autoria.

Imagem 12 - Trombócitos agregados (seta). Lente objetiva de 10X.

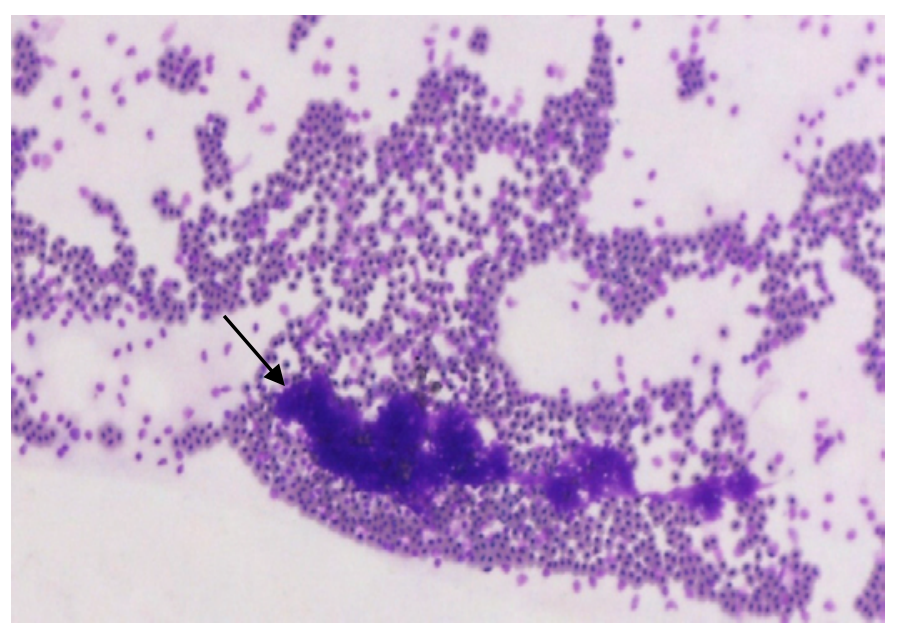

Fonte: Própria autoria. 
Imagem 13 - Anisocitose e policromasia. Lente objetiva de 100X.

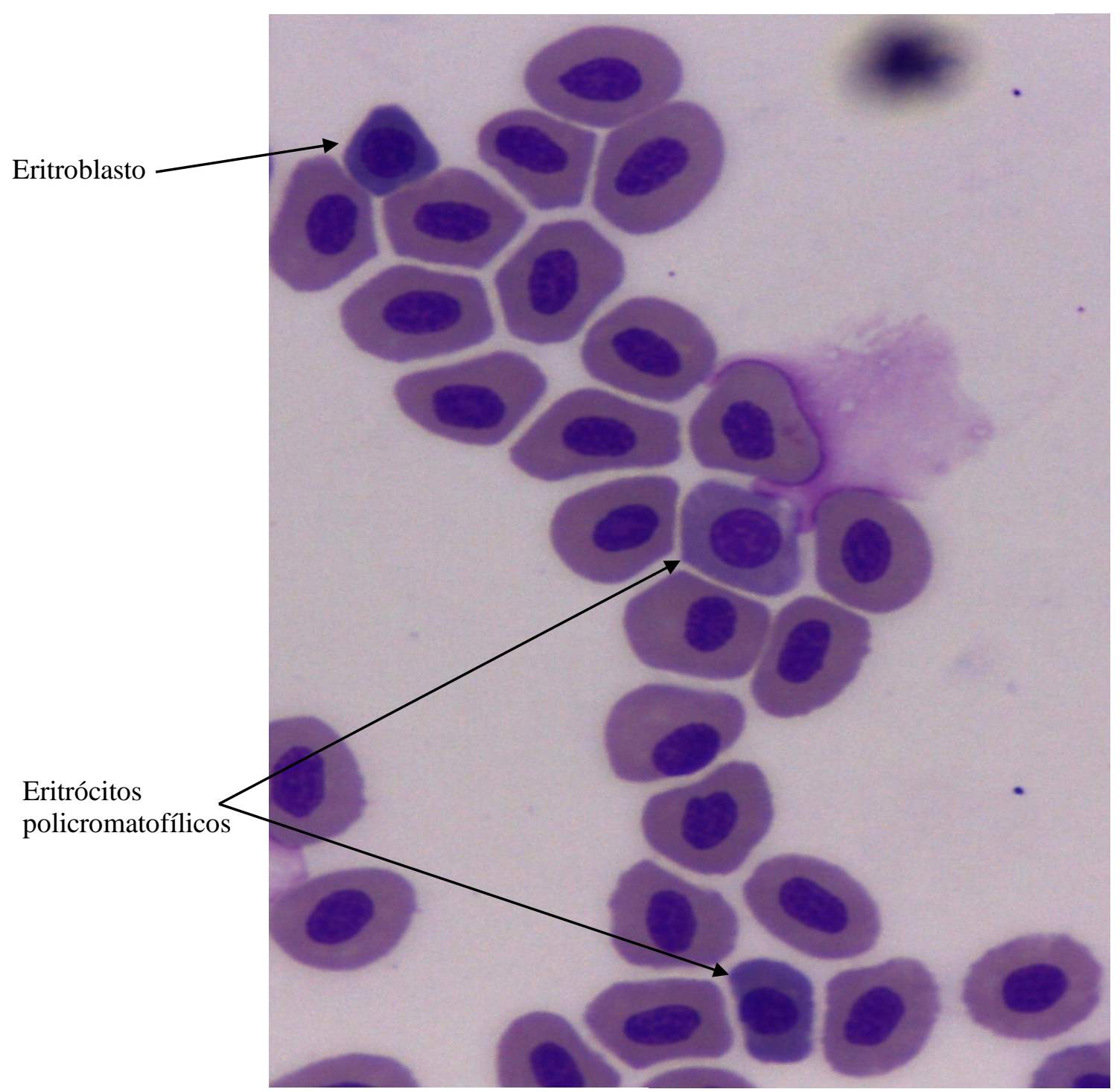

Fonte: Própria autoria.

Imagem 14 - Linfócitos (setas). Lente objetiva de 100X.

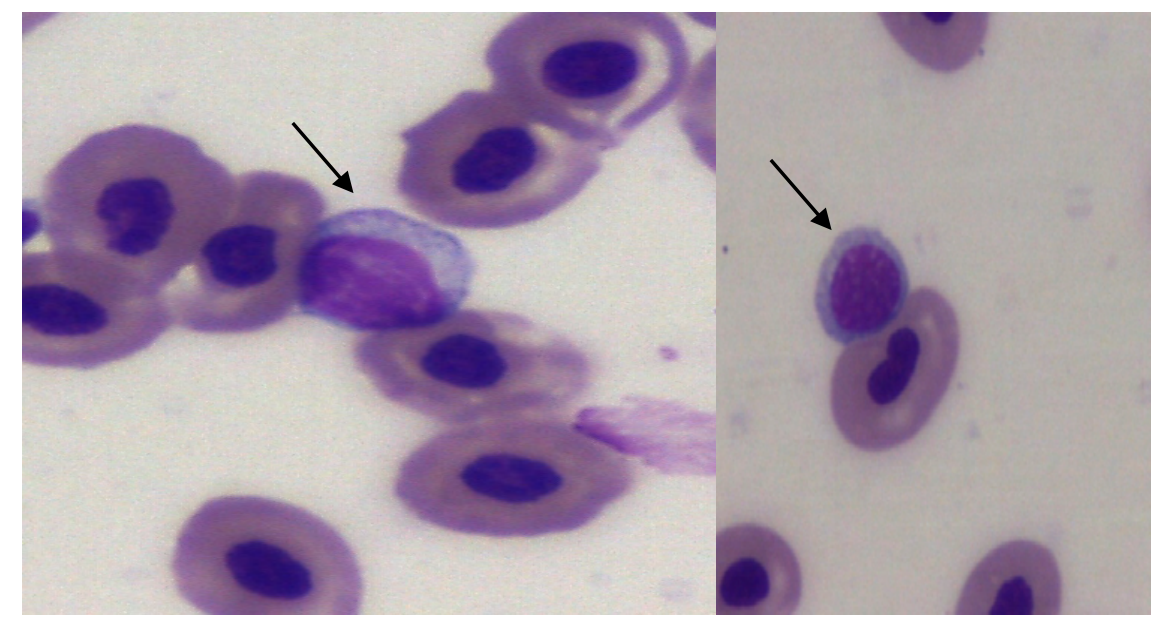

Fonte: Própria autoria. 
Imagem 15 - Linfócitos reativos (setas). Lente objetiva de 100X.

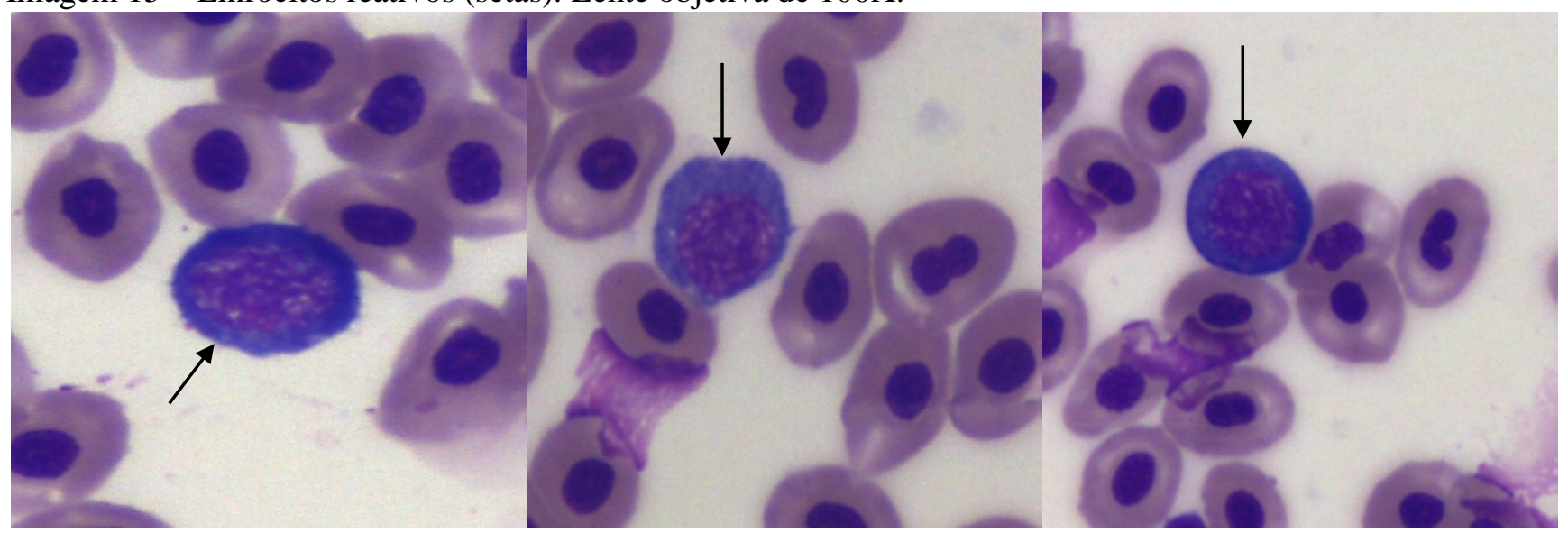

Fonte: Própria autoria.

Imagem 16 - Monócitos (setas). Lente objetiva de 100X.

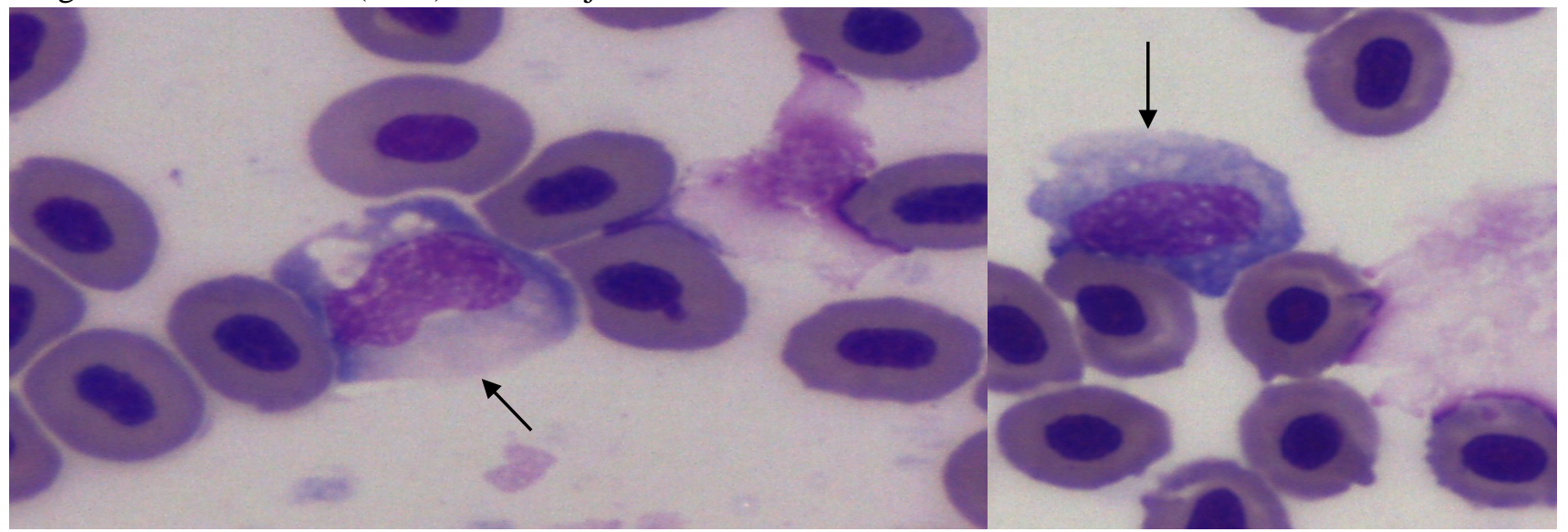

Fonte: Própria autoria.

Imagem 17 - Neutrófilos (setas). Lente objetiva de 100X.

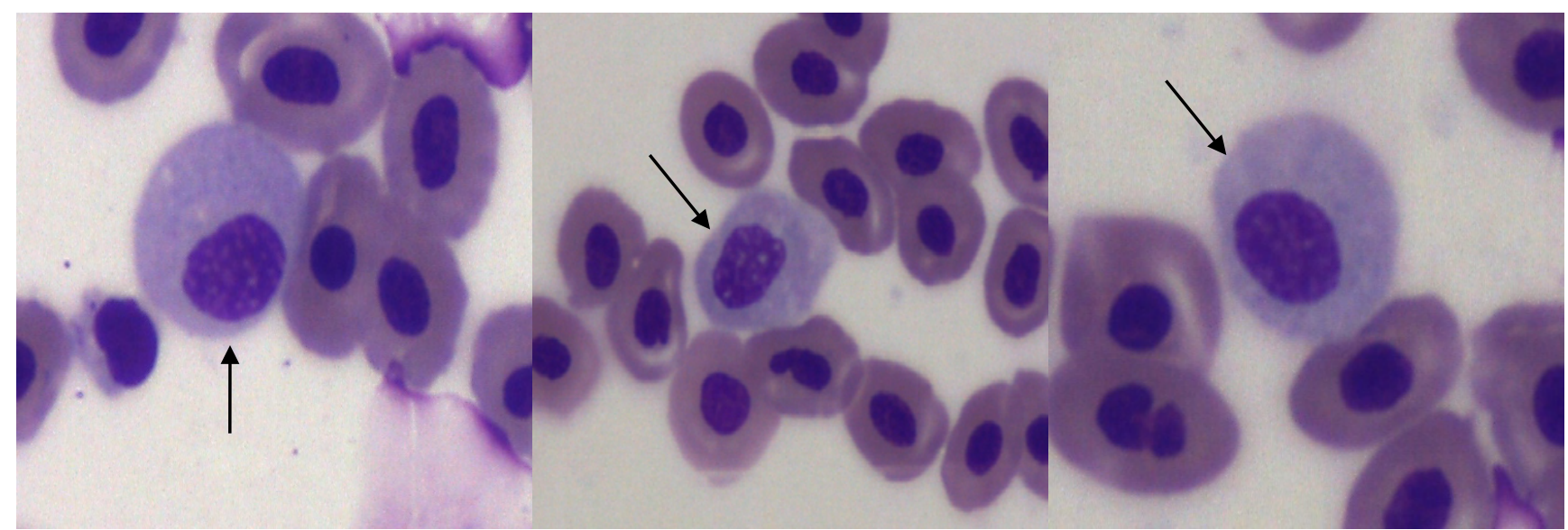

Fonte: Própria autoria. 
Imagem 18 - Eosinófilos (setas). Lente objetiva de 100X.

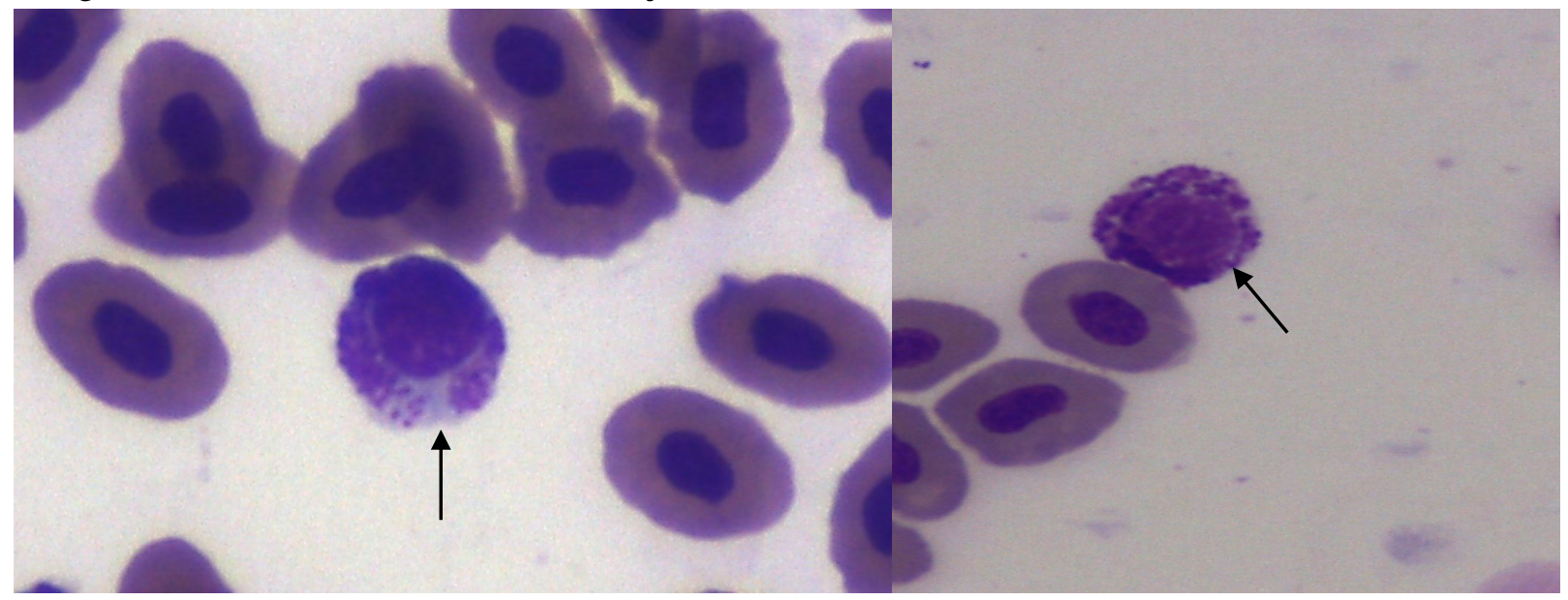

Fonte: Própria autoria.

Imagem 19 - Basófilo (seta). Lente objetiva de 100X.

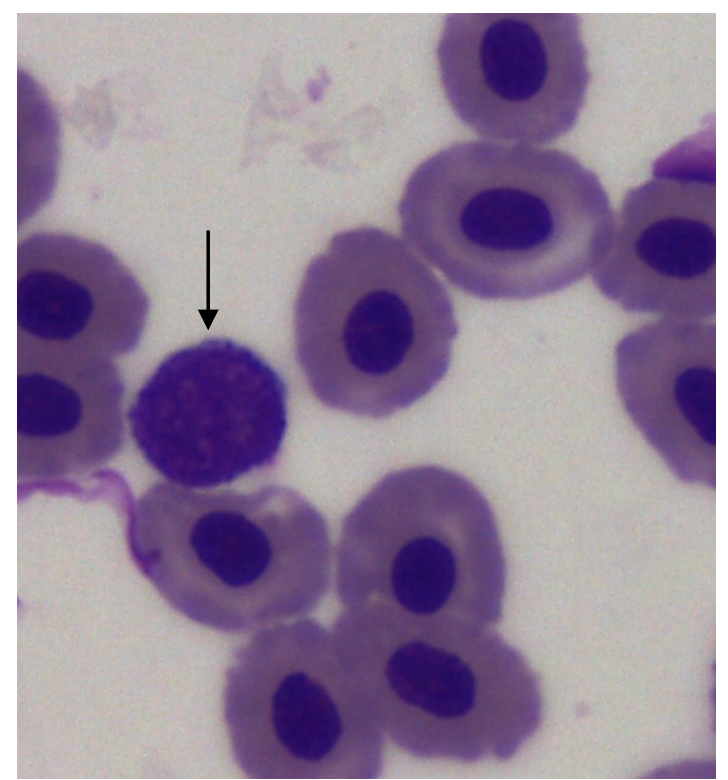

Fonte: Própria autoria. 


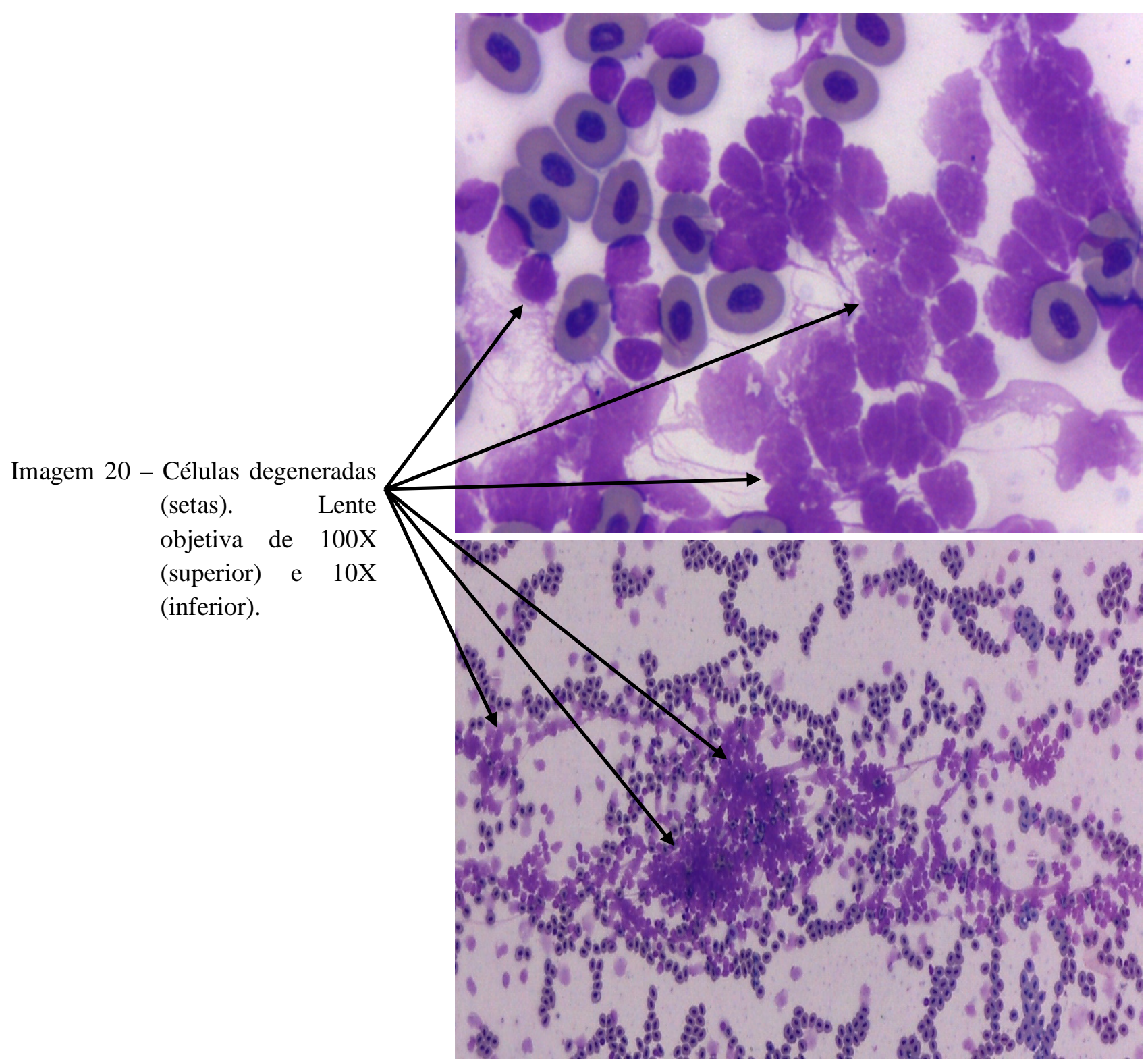

Fonte: Própria autoria.

\subsection{BIOQUÍMICA PLASMÁTICA EM ALEVINOS DE TILÁPIA}

\subsubsection{Enzima alanina aminotransferase}

Os resultados avaliados para as enzimas ALT demonstraram que houve significância estatística para o efeito dos dias $(p<0,05)$. Já para o efeito da concentração de vírus utilizada, o valor de $p$ não apresentou significância $(p=0,873)$. A relação da interação concentração/dia foi de $p=0,713$. 


\subsubsection{Enzimas aspartato aminotransferase}

Não foram observadas significâncias estatísticas relacionadas aos efeitos dos dias $(p=0,39)$, da concentração $(p=0,35)$ e da interação entre concentração/dia ( $p=$ $0,49)$ para as enzimas AST.

\section{8 ÍNDICES SOMÁTICOS EM ÓRGÃOS DE ALEVINOS DE TILÁPIA}

Houve interação estatisticamente significativa (concentração/dia) para a relação hepato-somática (IHS: $p<0,01$ ) e espleno-somática (IES: $p<0,05$ ) em animais experimentalmente desafiados com Ranavirus.

\subsection{ESTATÍSTICA LEUCOGRAMA}

Não foram detectadas significâncias estatísticas (concentração, dia e interação entre concentração/dia) associadas ao leucograma (leucócitos, neutrófilos, linfócitos, monócitos, eosinófilos e basófilos) nos animais infectados experimentalmente com Ranavirus FV3-like.

\subsection{PCR CONVENCIONAL PARA RANAVIRUS}

Para identificação de possíveis animais positivos, nos momentos pré e pósinfecção com Ranavirus, foi realizada a reação em cadeia pela polimerase (PCR), imagem 21. 
Imagem 21 - Fotografia de gel de agarose corado com SYBR ${ }^{\circledR}$ Gold, sob luz UV, ilustrando resultado de amplificação de amostras de DNA extraído de tecidos de larvas e de alevinos de tilápia utilizados no presente projeto, incluindo controle negativo (água DEPC) mais fragmento amplificado de controle positivo, referente a 321pb do gene MCP do genoma de Ranavirus.

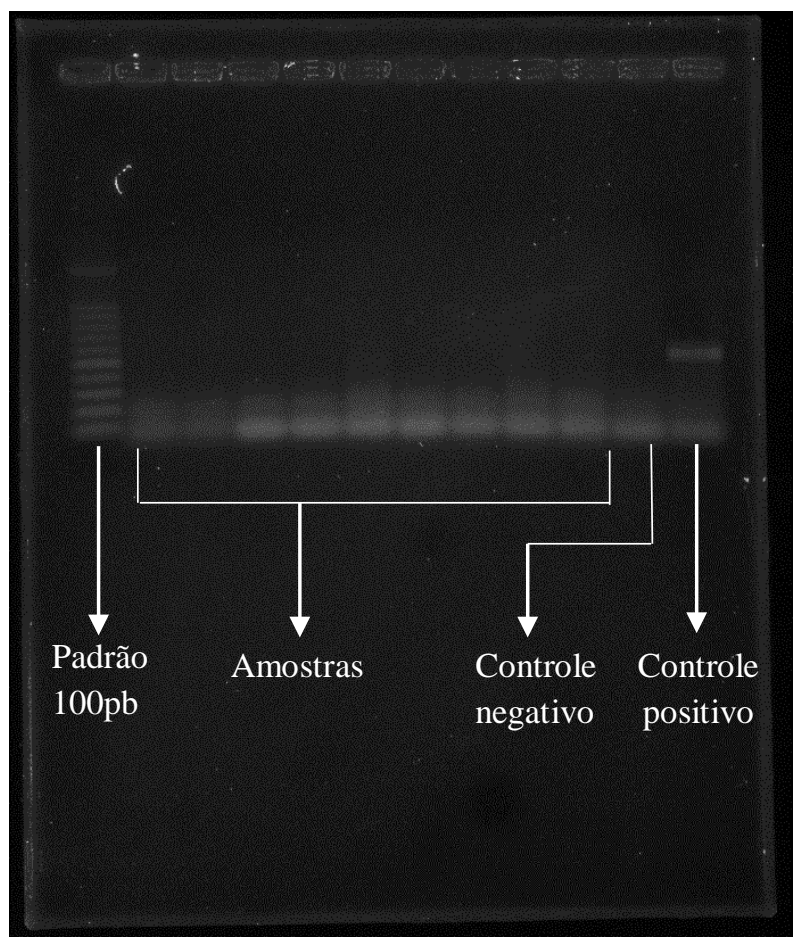

Fonte: Própria autoria.

Não foram identificados animais positivos para Ranavirus através de PCR convencional, nos momentos pré e pós-infecção experimental (tanto em larvas como em alevinos de tilápia coabitando ou infectados através de injeção intraperitoneal).

\subsection{DETECÇÃO E QUANTIFICAÇÃO DA CARGA VIRAL ATRAVÉS DE PCR QUANTITATIVO EM TEMPO REAL EM LARVAS E ALEVINOS DE TILÁPIA DO NILO INFECTADOS EXPERIMENTALMENTE COM RANAVIRUS}

\subsubsection{Padronização de eficiência dos primers utilizados para quantificação absoluta de Ranavirus através de PCR quantitativo em tempo real}

Após testes realizados com seis diferentes concentrações de DNA extraído de Ranavirus FV3-like isolado em cultura de células BF-2 e três de primers (tabela 4), concluímos que a melhor eficiência da reação se deu na concentração de 400nM (imagem 22). 
Imagem 22 - Curva de amplificação em qPCR para cálculo de eficiência de primer a 400nM.

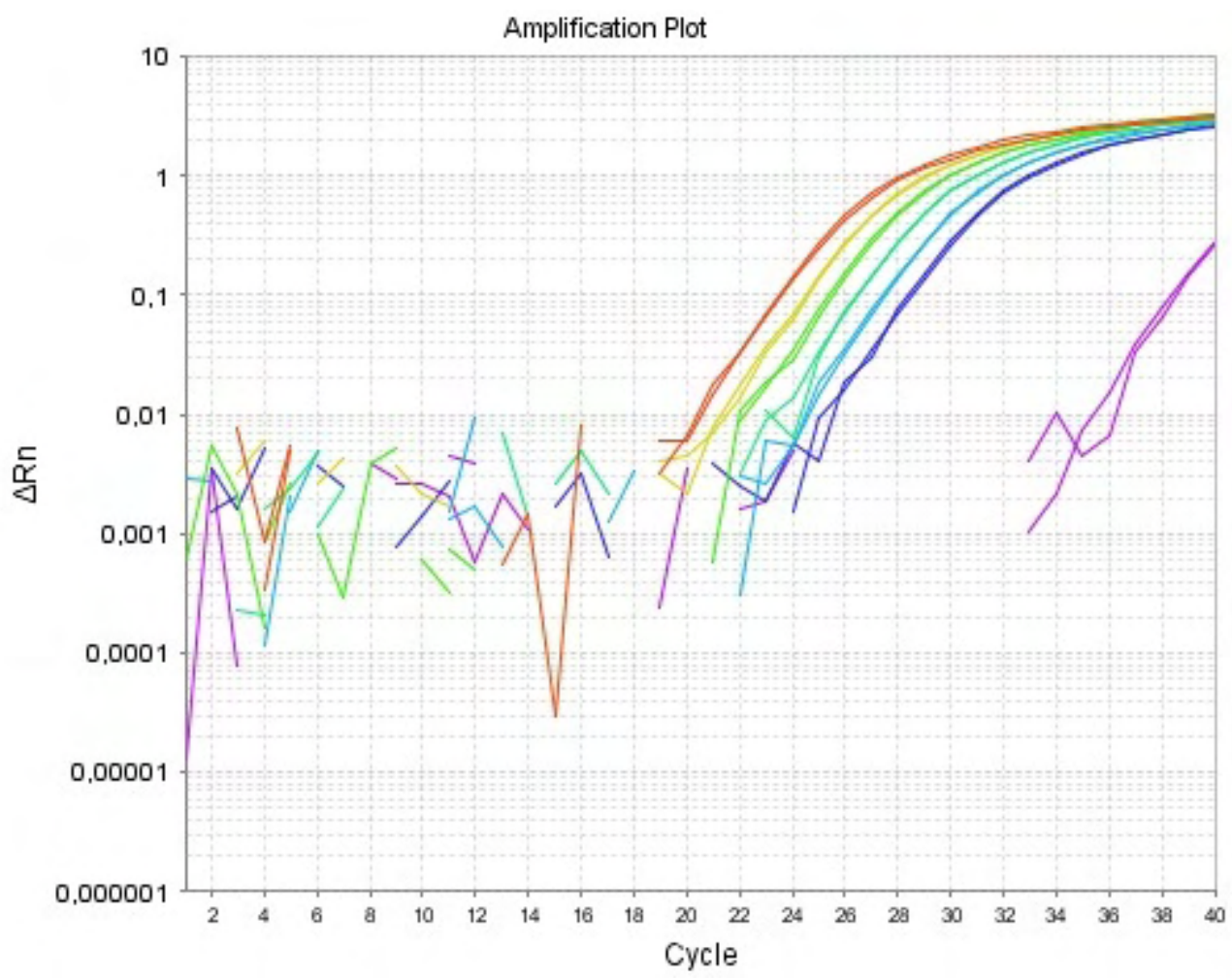

Legenda: As amostras de DNA de Ranavirus extraído de cultura de células (BF-2) estão nas seguintes concentrações, em sequência: $50 \mathrm{ng} / \mu \mathrm{L}$ vermelha; $25 \mathrm{ng} / \mu \mathrm{L}$ amarela; $12,5 \mathrm{ng} / \mu \mathrm{L}$ verde claro; $6,25 \mathrm{ng} / \mu \mathrm{L}$ verde escuro; $3,125 \mathrm{ng} / \mu \mathrm{L}$ azul; e $1,56 \mathrm{ng} / \mu \mathrm{L}$ roxo.

Fonte: Própria autoria.

\subsubsection{Curva padrão para PCR quantitativo absoluto em tempo real}

A sensibilidade analítica determinada com diluições seriadas na base 10 foi de $1.8 \times 10^{3}$ cópias de $\mathrm{DNA} / \mu \mathrm{L}$, com $C t=29,38$, o qual correspondeu à diluição de $10^{-6}$ do DNA padrão (tabela 6, imagens 23 e 24). Para a quantificação da carga viral de Ranavirus nos animais experimentalmente infectados, foram selecionadas seis diluições $\left(10^{-1}\right.$ a $\left.10^{-6}\right)$. O Ct pode ser determinado pela intersecção da linha do limiar de detecção da reação, através do threshold, com a curva de amplificação de cada diluição.

As amostras que apresentaram $C t \leq 29,38$ e valores próximos ao exibido pela curva padrão foram consideradas positivas. A reação de PCR quantitativa foi realizada em duplicata visando garantir a repetibilidade do ensaio. 
Imagem 23 - Curva de amplificação em PCR quantitativo absoluto para Ranavirus, a partir de diluições seriadas de DNA purificado $\left(10^{-1}\right.$ a $\left.10^{-6}\right)$.

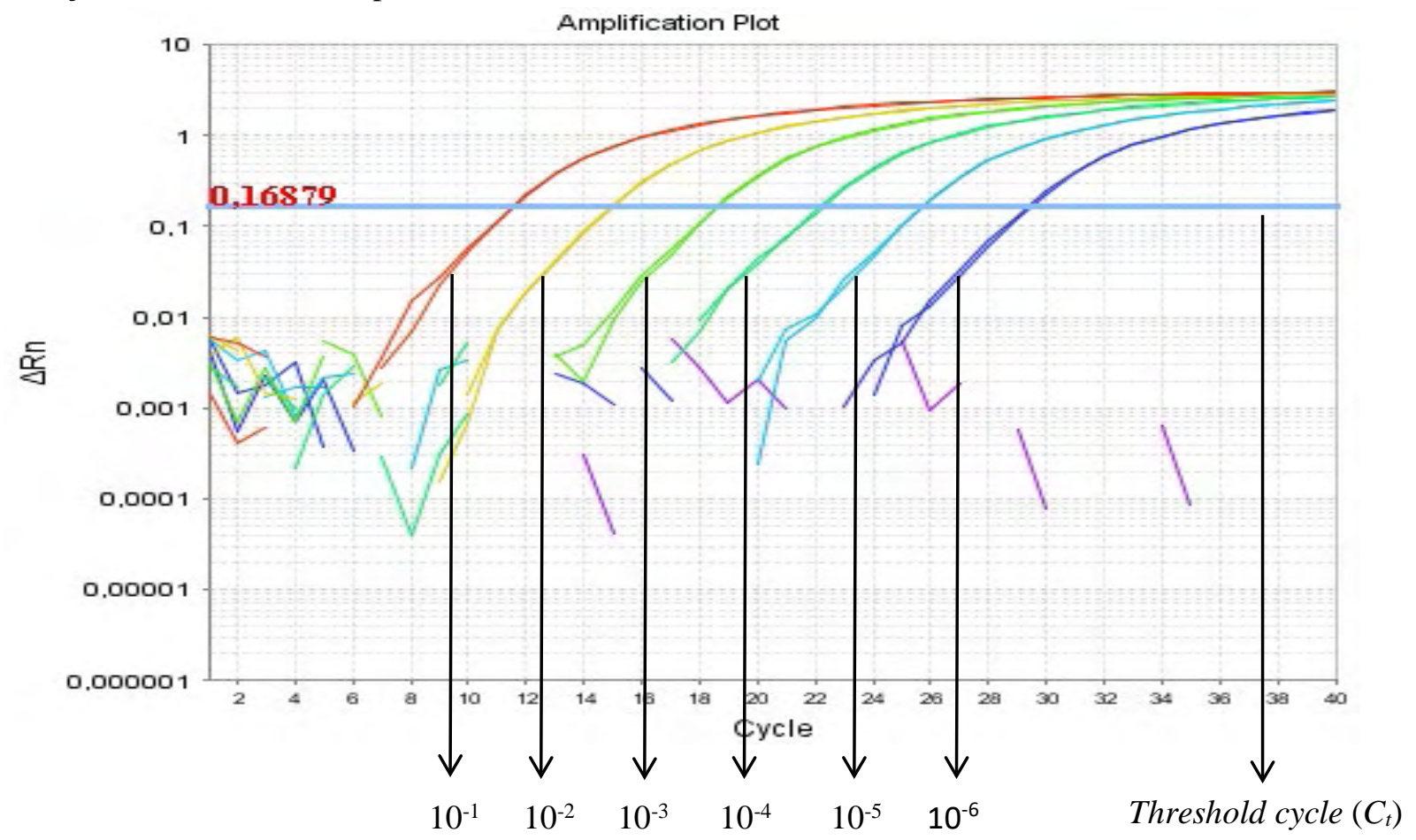

Fonte: Própria autoria.

Imagem 24 - Curva padrão para qPCR a partir de diluições seriadas de base 10 de fragmento amplificado do gene MCP de Ranavirus, realizada com o sistema TaqMan.

\section{Curva Padrão}

$$
\begin{gathered}
y=-3,5776 x+7,8795 \\
R^{2}=0,9999
\end{gathered}
$$

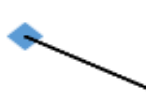

Ł

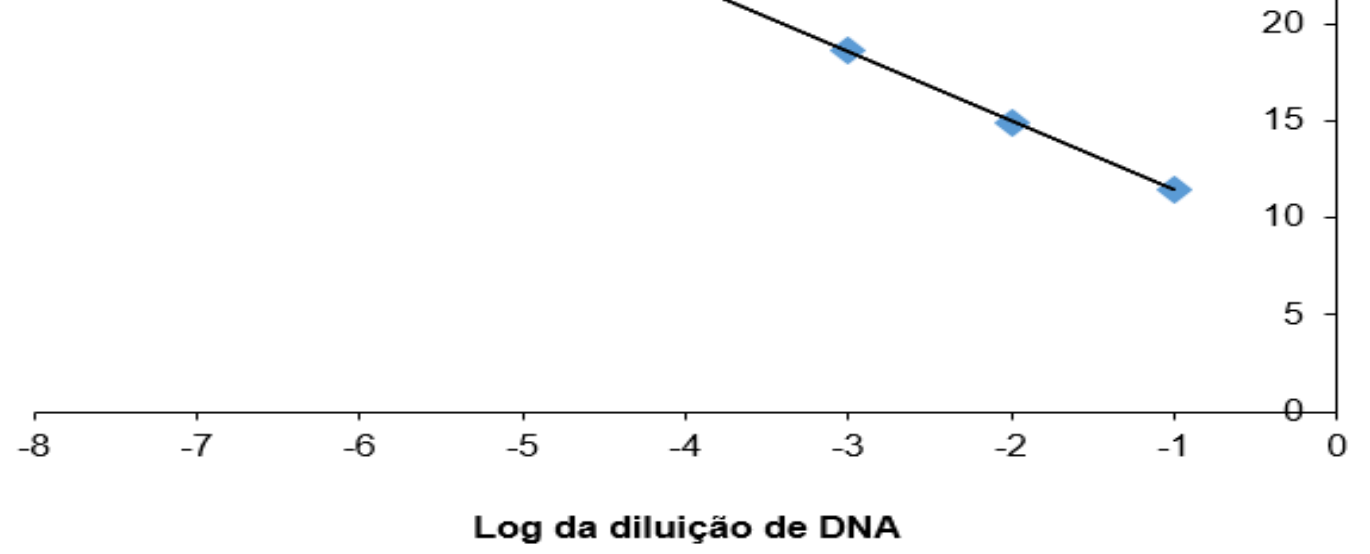

Legenda: Valores da reação: Eficiência = 1,9032 (90,33\%); Coeficiente de correlação $\left(\mathrm{R}^{2}\right)=0,9999$. Fonte: Própria autoria. 
Tabela 6 - Diluição seriada para construção da curva padrão em qPCR com valores médios de Ct e cópias de DNA.

\begin{tabular}{ccc}
\hline Diluições do DNA padrão & Médias do $C \boldsymbol{t}$ & Médias de cópias de DNA \\
\hline $10^{-1}$ & 11,52 & $1.8 \times 10^{8}$ \\
$10^{-2}$ & 14,94 & $1.8 \times 10^{7}$ \\
$10^{-3}$ & 18,65 & $1.8 \times 10^{6}$ \\
$10^{-4}$ & 22,15 & $1.8 \times 10^{5}$ \\
$10^{-5}$ & 25,73 & $1.8 \times 10^{4}$ \\
$10^{-6}$ & 29,38 & $1.8 \times 10^{3}$ \\
\hline
\end{tabular}

Fonte: Própria autoria.

\subsubsection{Quantificação da carga viral através de PCR quantitativo absoluto em tempo real em animais experimentalmente infetados com Ranavirus FV3-like}

Foram analisadas quantitativamente para Ranavirus todas as amostras extraídas de alevinos e de larvas de tilápia, além das amostras controle.

As amostras teciduais extraídas de alevinos apresentaram $C t>35$ para Ranavirus e, desta forma, consideraram-se os resultados como negativos para a presença do vírus nas amostras analisadas (animais desafiados e controle). Valores de $C t \geq 35$ podem representar artefatos de amplificação ou fluorescência, ou contaminação cruzada. Portanto, deve-se ter cautela na interpretação de tais valores (CARAGUEL et al., 2011).

Imagem 25 - Resultado de PCR quantitativo absoluto em tempo real, a partir de amostras de alevinos de tilápia do Nilo infectados experimentalmente com Ranavirus FV3-like, através de injeção intraperitoneal e coabitação.

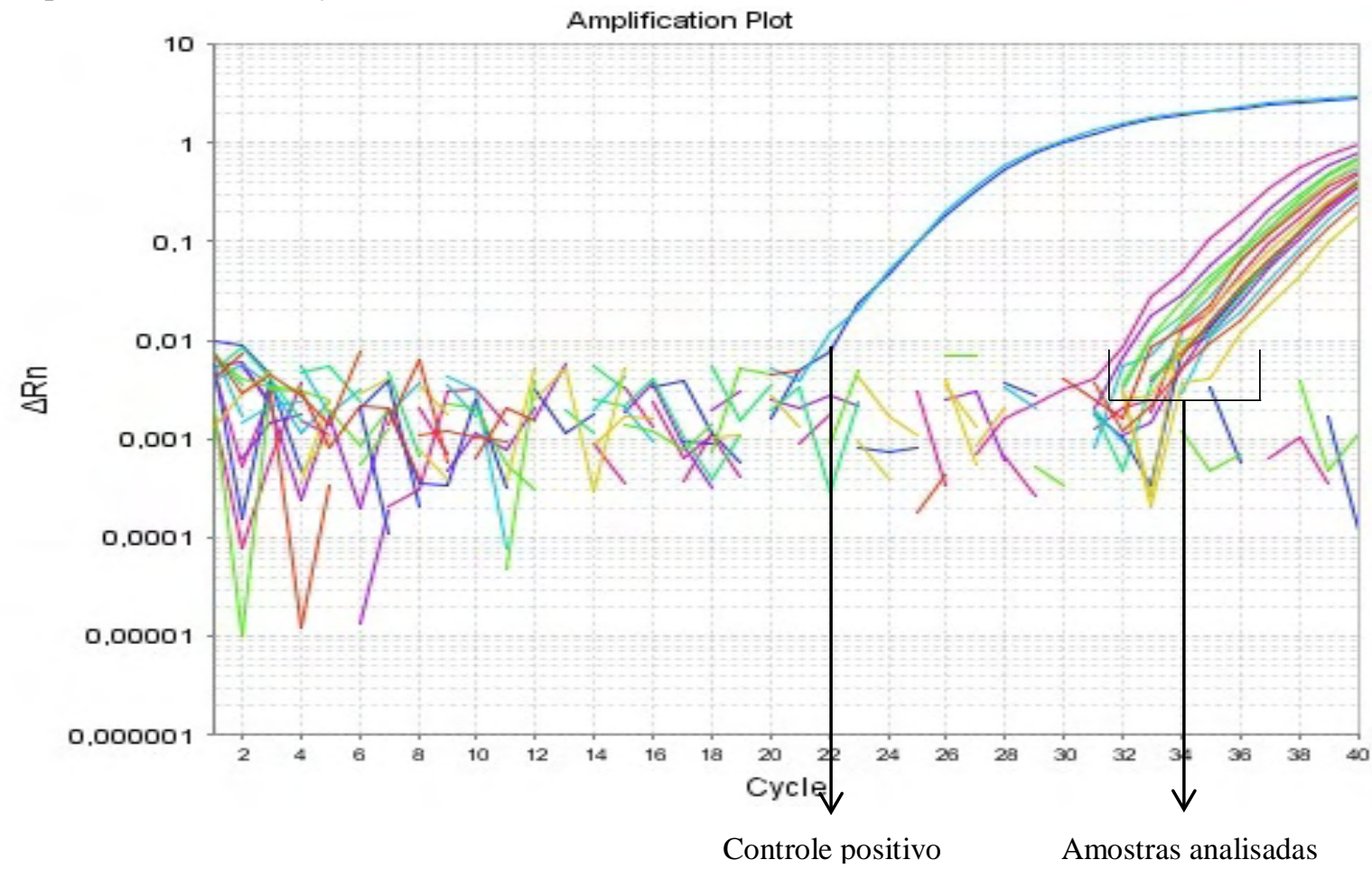

Legenda: O controle positivo apresenta amplificação iniciada em torno do ciclo 21, as amostras de DNA extraídas de diferentes órgãos dos animais apresentam início de amplificação tardia, entre os ciclos 31 a 34, com $C t>35$. O Ct foi retirado da imagem para melhor ilustrar o início e seguimento das amplificações.

Fonte: Própria autoria. 
Em relação às larvas infectadas experimentalmente com Ranavirus FV3like, os animais dos tanques onde a concentração viral era de $10^{3}$ TCID $_{50} / \mathrm{mL}$, e que foram coletados nos dias 11 e 60 pós-infecção, foram positivos ao vírus, apresentando amplificação com início no ciclo 30 e Ct de 34,2 (imagens 26 e 27), quando ajustado ao Ct da curva padrão, que foi de 0,168 .

Imagem 26 - Resultado de PCR quantitativo absoluto em tempo real, a partir de pool de tecidos de larvas de tilápia do Nilo infectadas experimentalmente com Ranavirus.

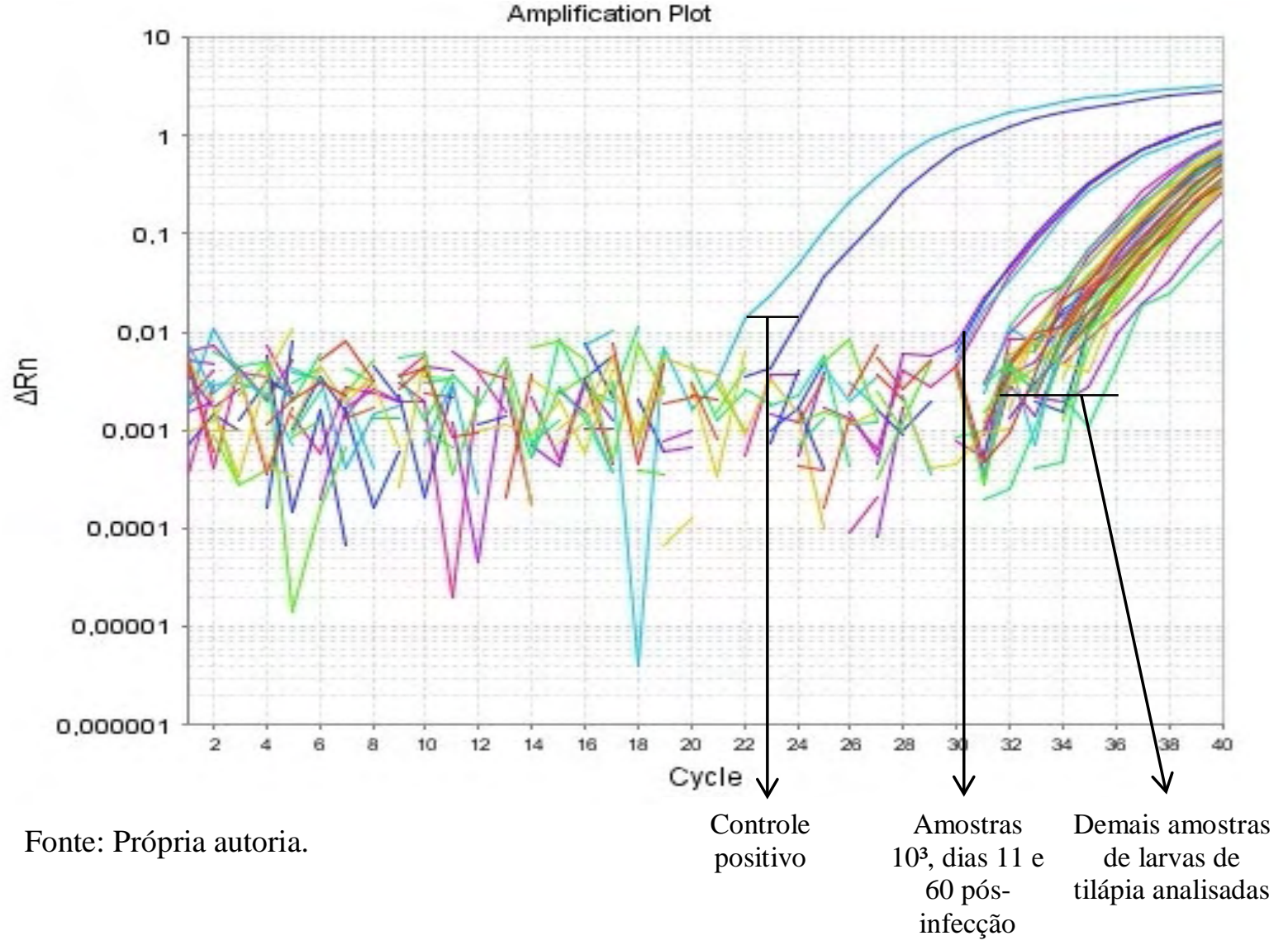


Imagem 27 - Repetição da amostra de larva de tilápia infectada experimentalmente com Ranavirus na concentração de $10^{3} \mathrm{TCID}_{50} / \mathrm{mL}$, dia 11 pós-infecção, com $C t$ ajustado para 0,168 (mesmo valor da curva padrão).

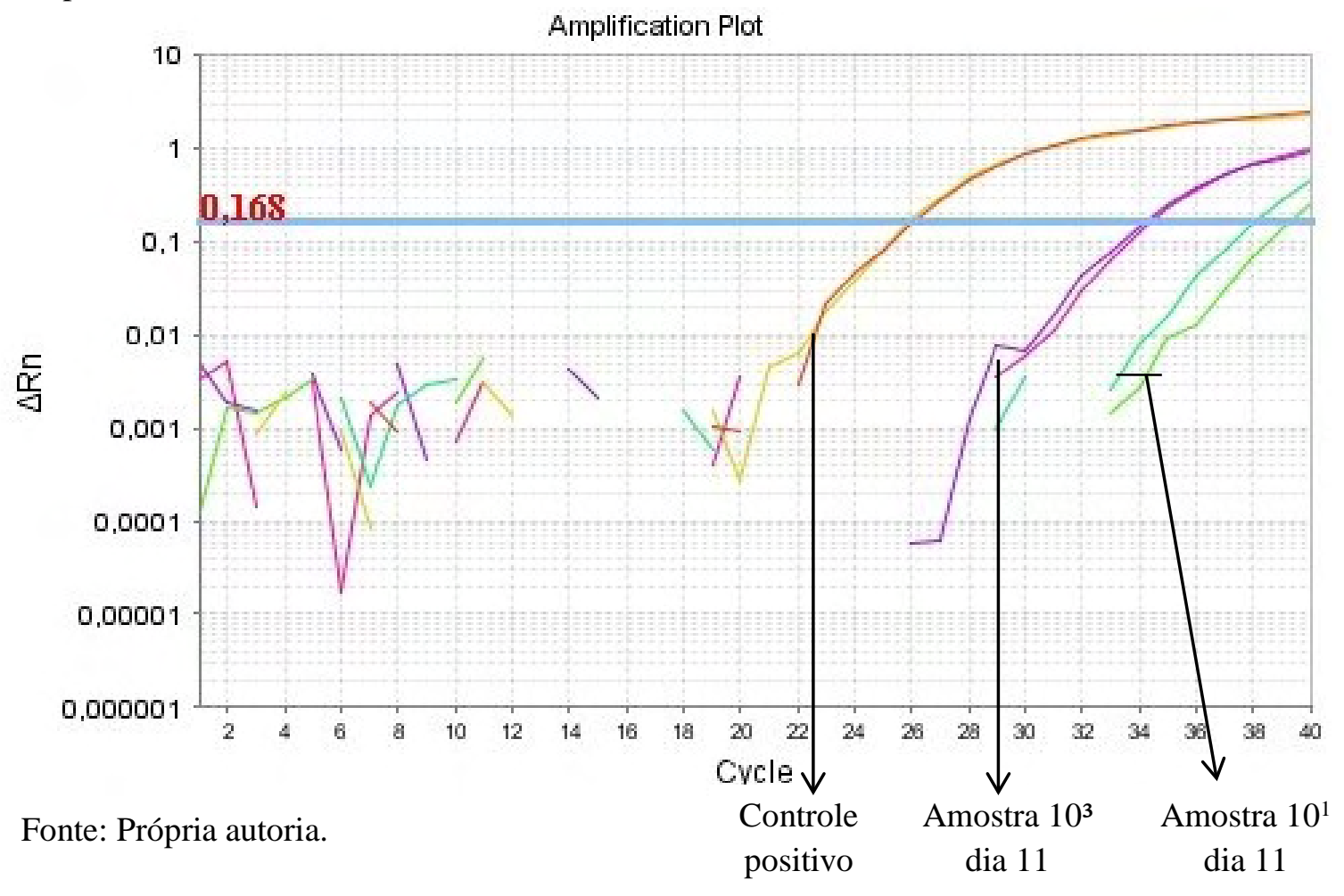

Quando ajustado ao valor do Ct da curva padrão $(0,168)$, as amostras extraídas de larvas de tilápia do Nilo experimentalmente infectadas com Ranavirus FV3-like, na concentração de $10^{3}$ TCID $50 / \mathrm{mL}$, dias 11 e 60 pós-infecção experimental, apresentaram $C t$ de 34,2 que equivale a 77 cópias de DNA amplificadas. O controle positivo apresentou Ct de 26,00 que equivale a 15.891 cópias de DNA amplificadas.

\subsection{HISTOPATOLOGIA EM LARVAS DE TILÁPIA}

Foram identificadas inúmeras alterações nos órgãos analisados em diferentes dias pós-infecção, comparativamente aos animais do grupo controle. As alterações mais expressivas ocorreram em animais infectados a partir da concentração $10^{2}$ TCID $50 / m L$ de FV3 e do $25^{\circ}$ dia pós-infecção e incluíram: pancreatite aguda, hepatite com áreas necrosadas, túbulos renais vacuolizados e hialinizados, enterite necrótica e descamativa, inúmeros pequenos melanomacrófagos no parênquima hepático e grandes melanomacrófagos na cápsula hepática e no tecido cardíaco, acúmulo de células inflamatórias no hepatopâncreas, autólise em áreas do intestino e do pâncreas, áreas tubulares vacuolizadas hemorrágicas, 
fibras cardíacas dissociadas, miocardite, rarefação citoplasmática, congestão de vasos sanguíneos, calcificação distrófica, congestão dos vasos centrais acinares pancreáticos e melanocarcinoma na cápsula renal. Grande quantidade de estruturas sugestivas de corpúsculos de inclusão basofílicos em diferentes tecidos dos animais experimentalmente infectados, característicos de infecção por Ranavirus, foi identificada (imagens 28 e 29), porém ausentes nos animais do grupo controle. Os resultados indicam que a infecção por estirpe brasileira de FV3 em larvas de tilápia do Nilo provocou uma grande quantidade de alterações teciduais microscópicas nos espécimes infectados, porém, sem sinais macroscópicos. Estudos posteriores sobre o desempenho zootécnico de animais infectados por esse vírus serão necessários para a melhor compreensão do impacto dessa virose na produção de tilápias no Brasil.

Imagem 28 - Histopatologia em larvas de tilápia do Nilo infectadas experimentalmente com estirpe brasileira de Ranavirus FV3-like. Nas ilustrações (A, B e C), indicado por setas brancas, observam-se estruturas sugestivas de corpúsculos de inclusão basofílicos em tecidos renais dos animais analisados.

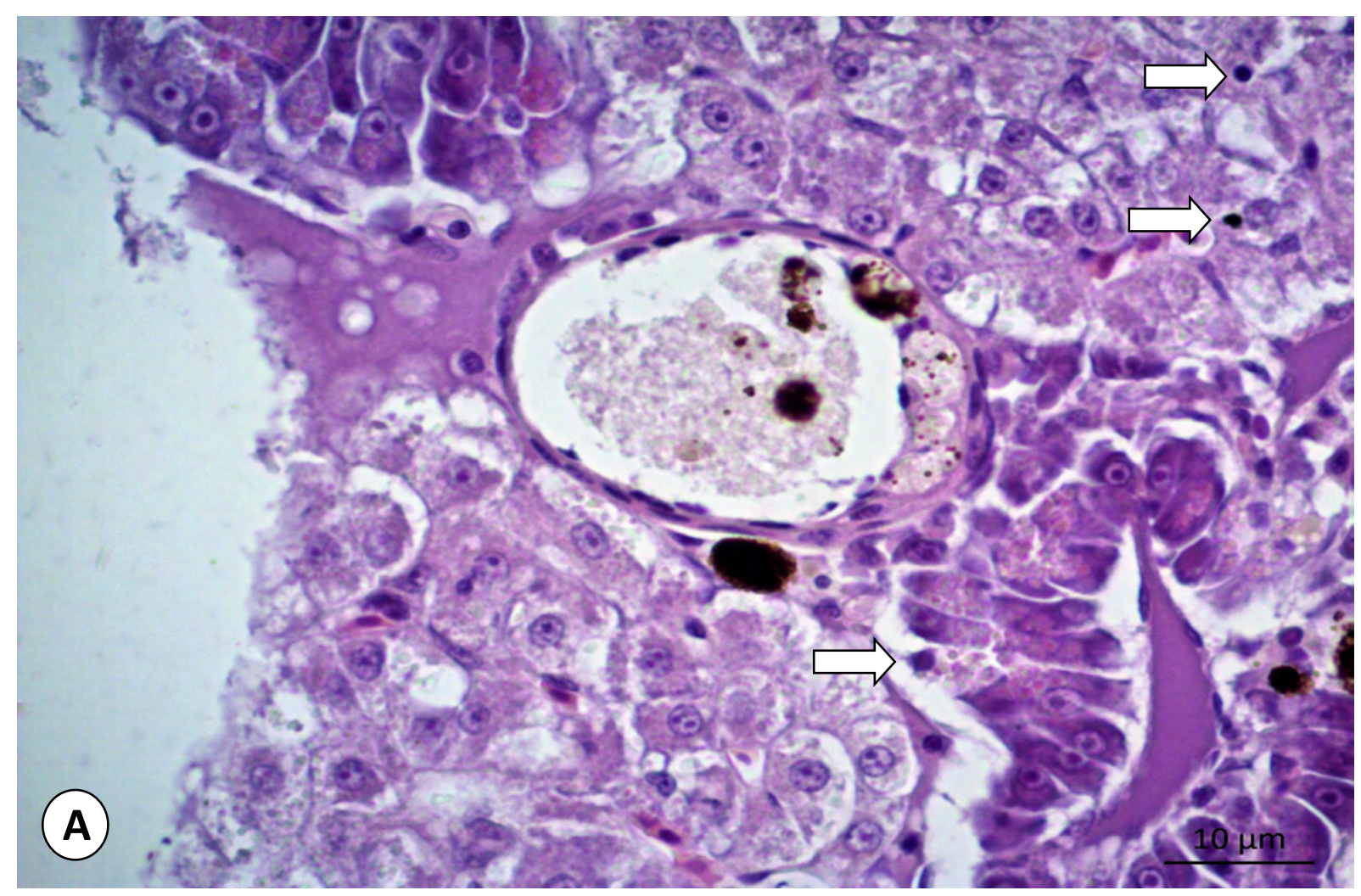



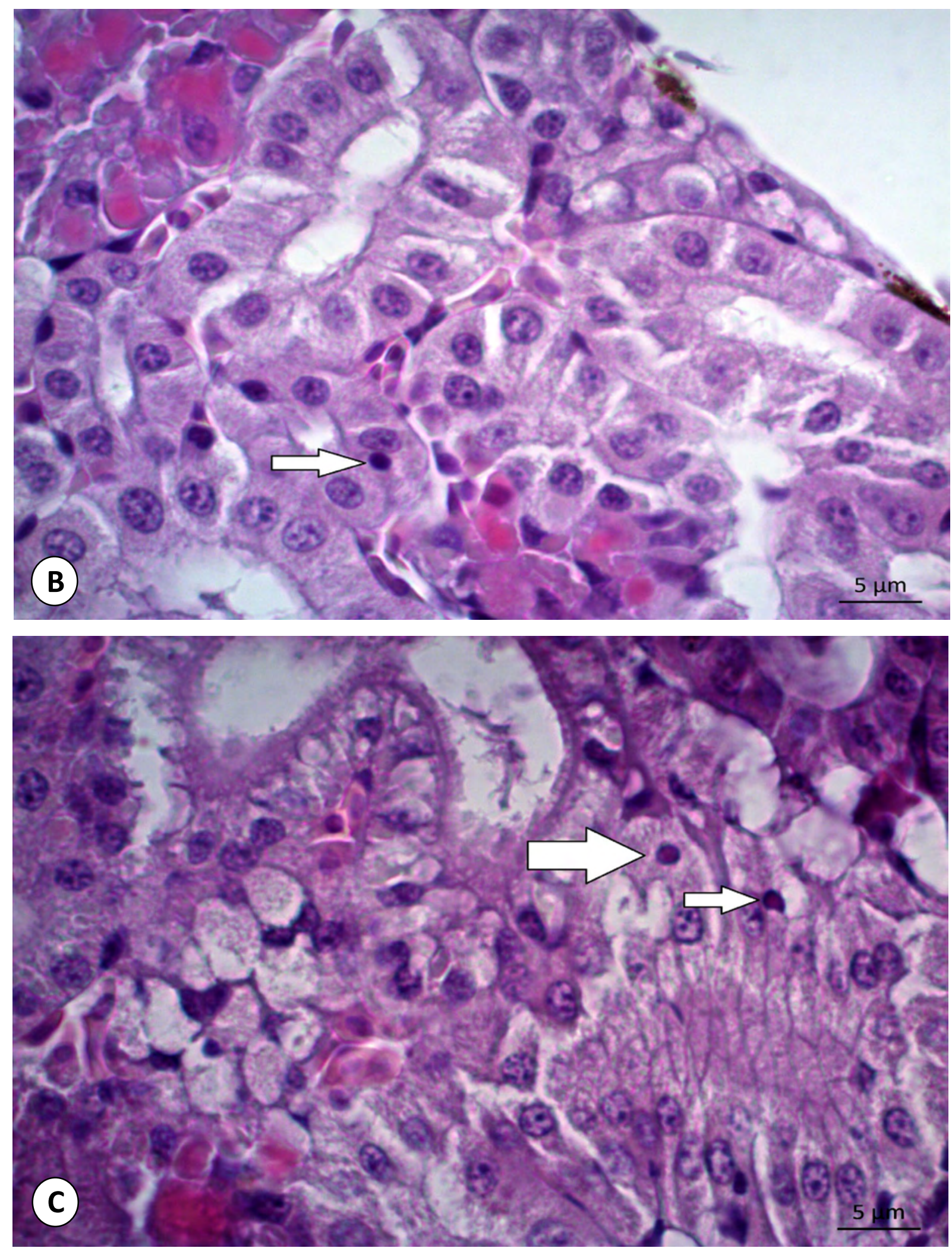

Legenda: A. Animal desafiado em concentração de $10^{3}$ TCID $50 / \mathrm{mL}$ de FV3, dia 60 pós-infecção. B. Animal desafiado em concentração de $10^{4} \mathrm{TCID}_{50} / \mathrm{mL}$ de $\mathrm{FV} 3$, dia 26 pós-infecção. C. Animal desafiado em concentração de $10^{2} \mathrm{TCID}_{50} / \mathrm{mL}$ de FV3, dia 26 pós-infecção.

Fonte: Imagens cedidas pela Dra. Ana M. C. R. P. da Fonseca Martins, do Instituto Biológico de SP. 
Imagem 29 - Resultado histopatológico em tecidos cardíacos de larvas de tilápia do Nilo infectadas experimentalmente com estirpe brasileira de Ranavirus FV3-like, nas concentrações de $10^{3}$ (fotomicrografia A) e $10^{2}$ (fotomicrografia B) $\mathrm{TCID}_{50} / \mathrm{mL}$, dia 60 pós-infecção.
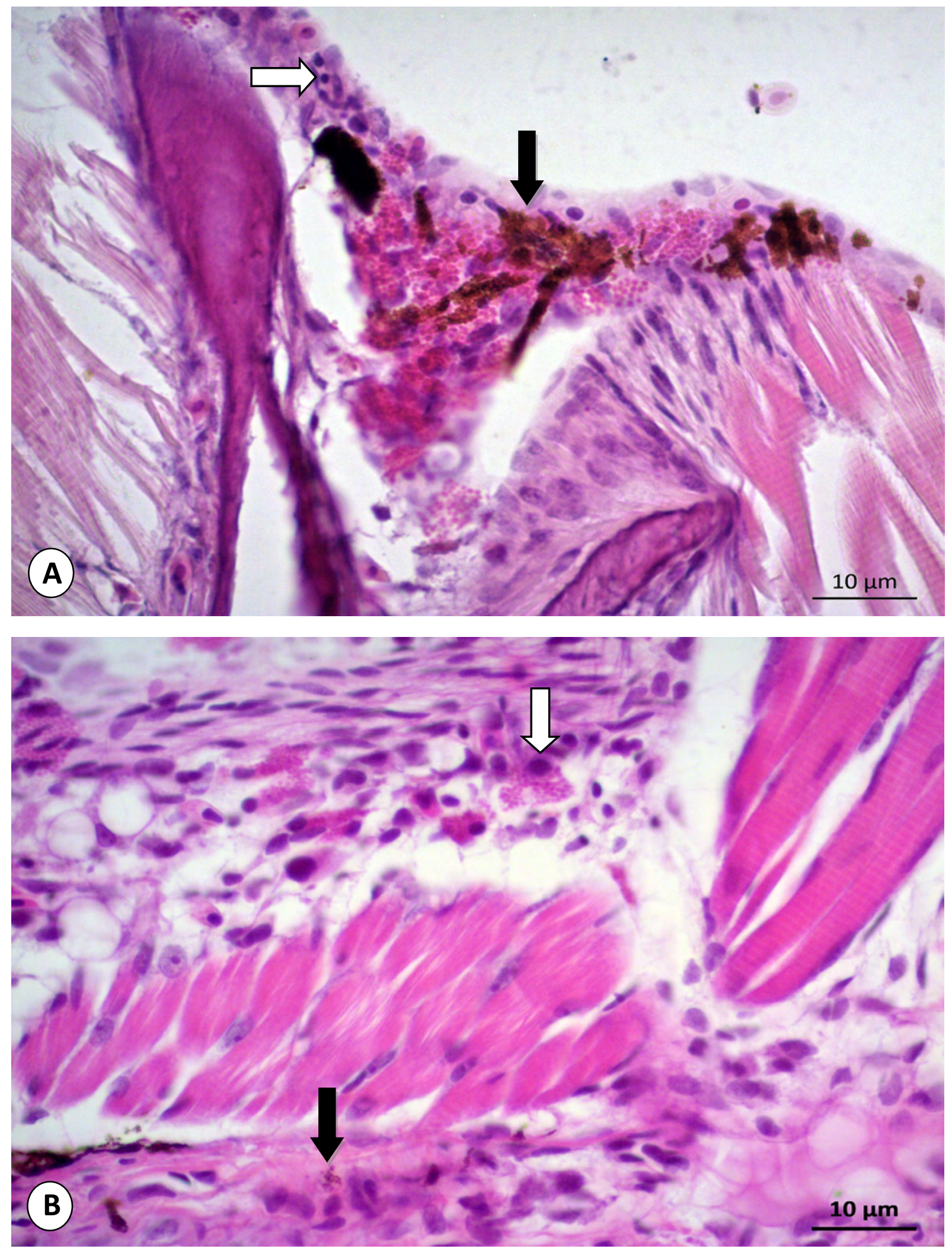

Legenda: Muitos eosinófilos e centros melanomacrófagos são observados no entorno de estruturas sugestivas de corpúsculos de inclusão basofílicos em ambas fotomicrografias. Fibras cardíacas dissociadas são observadas nas imagens, com maior intensidade na A. As setas brancas indicam corpúsculos de inclusão basofílicos e as setas pretas indicam centros melanomacrófagos.

Fonte: Imagens cedidas pela Dra. Ana M. C. R. P. da Fonseca Martins, do Instituto Biológico de SP. 
Imagem 30 - Resultado histopatológico em tecidos hepáticos de larvas de tilápia do Nilo infectadas experimentalmente com estirpe brasileira de Ranavirus FV3-like na concentração de $10^{3} \mathrm{TCID}_{50} / \mathrm{mL}$, dia 60 pós-infecção.


Legenda: Grandes focos de hepatite com áreas necrosadas são observados nas imagens.

Fonte: Imagens cedidas pela Dra. Ana M. C. R. P. da Fonseca Martins, do Instituto Biológico de SP. 
Imagem 31 - Resultado histopatológico em tecido cardíaco de larva de tilápia do Nilo infectada experimentalmente com estirpe brasileira de Ranavirus FV3-like na concentração de $10^{3} \mathrm{TCID}_{50} / \mathrm{mL}$, dia 60 pós-infecção.

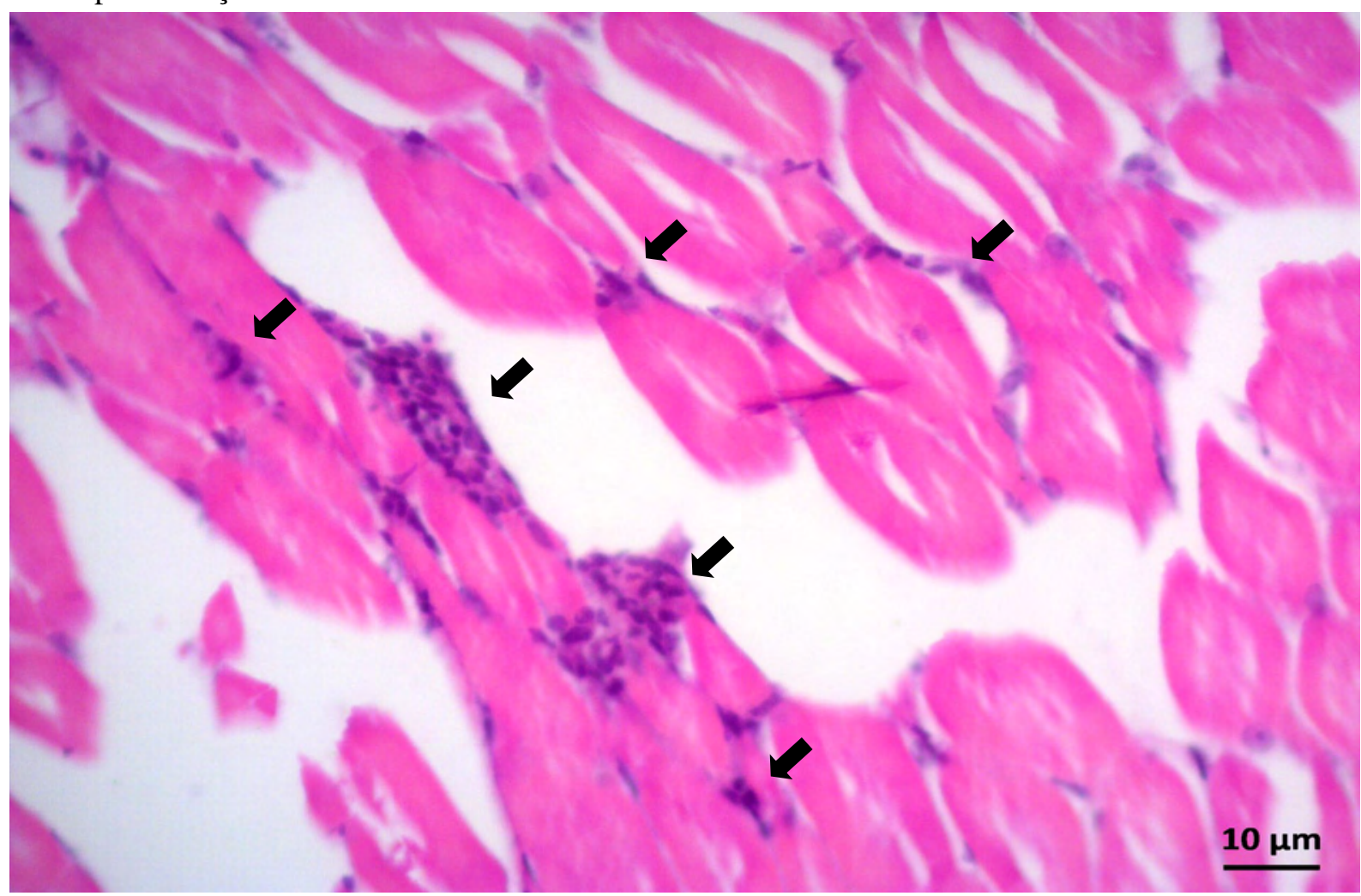

Legenda: Inúmeros pontos de miocardite (áreas inflamadas no tecido muscular), indicados por setas, são observados.

Fonte: Imagem cedida pela Dra. Ana M. C. R. P. da Fonseca Martins, do Instituto Biológico de SP.

\subsection{IMUNO-HISTOQUÍMICA EM LARVAS DE TILÁPIA}

Não foram evidenciadas lesões significativas nos cortes das larvas de tilápia examinadas (concentração de $10^{4} \mathrm{TCID}_{50} / \mathrm{mL}$ de Ranavirus FV3-like, dias 3 e 10 pós-infecção experimental).

Embora a coloração vermelha generalizada estivesse presente em ambos os animais examinados, após a realização da IHC com anticorpo anti-EHNV, a falta de especificidade e forte coloração das células do muco (como nas guelras) sugeriram uma inespecífica coloração de artefatos de fundo (imagem 32). A coloração IHC padronizada para Ranavirus infectando anfíbios parece não funcionar com tilápias do Nilo, pois há uma intensa coloração inespecífica de fundo. 
Imagem 32 - Larva de tilápia infectada experimentalmente com Ranavirus na concentração de $10^{4}$ $\mathrm{TCID}_{50} / \mathrm{mL}$, dia 10 pós infecção, corada com hematoxilina e eosina (H\&E) no topo e imunohistoquímica (IHC) na parte inferior, utilizando anticorpo de Ranavirus (anti-EHNV).

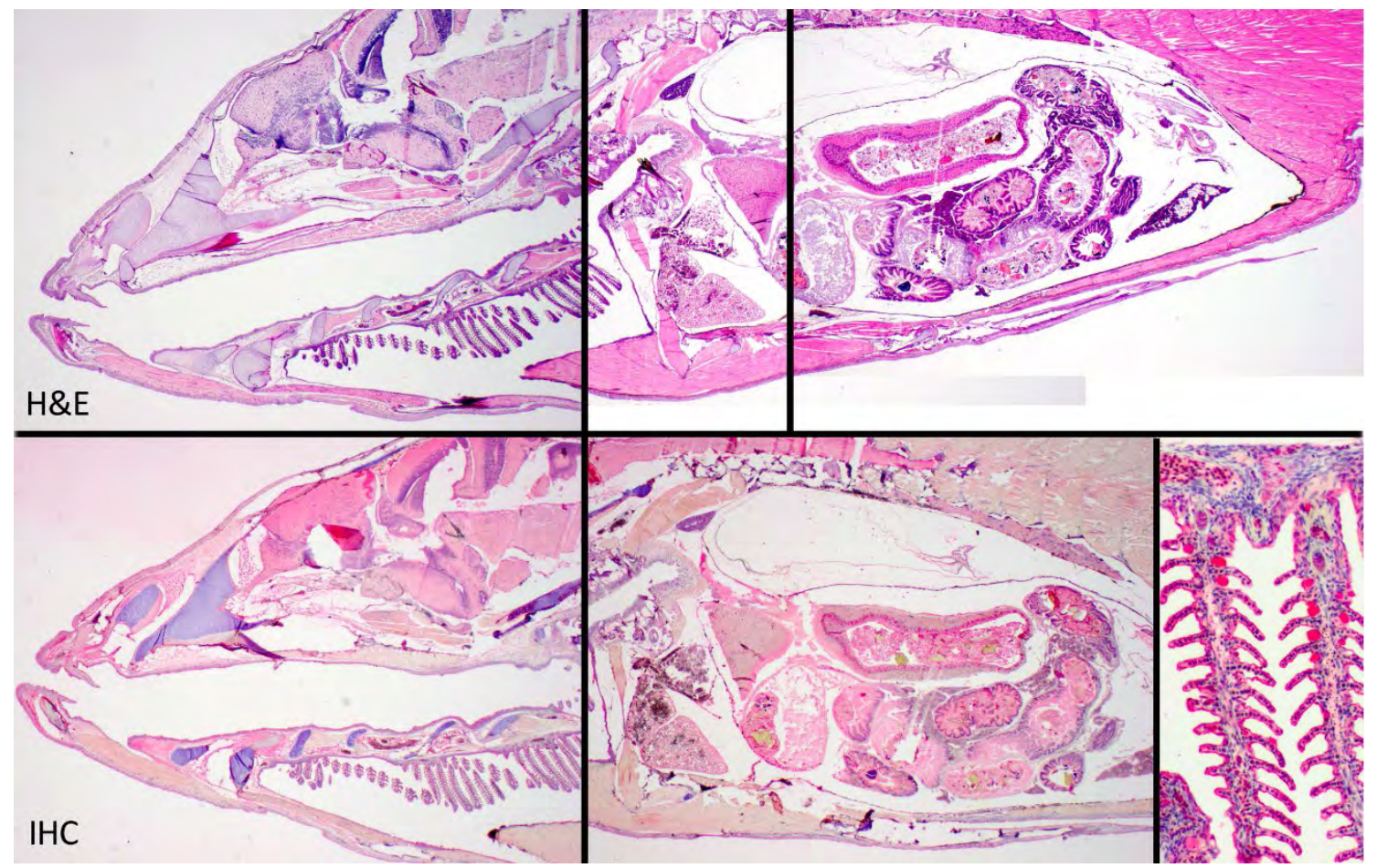

Legenda: A coloração IHC não específica de artefatos de fundo está difusa e mais intensa nas células de muco das brânquias - coloração de artefatos sem significância diagnóstica.

Fonte: Imagens cedidas pela Dra. María J. Forzán, da Cornell University, EUA.

\subsection{HIBRIDIZAÇÃO IN SITU EM LARVAS DE TILÁPIA}

A completa ausência de coloração com a sonda ISH para Ranavirus sugere que a coloração IHC era um artefato, e indicou que não há evidências de Ranavirus nos tecidos analisados (imagem 33).

Imagem 33 - Corte tecidual em larva de tilápia infectada experimentalmente com Ranavirus FV3-like na concentração de $10^{4} \mathrm{TCID}_{50} / \mathrm{mL}$, dia 10 pós infecção, submetido à coloração com ISH.

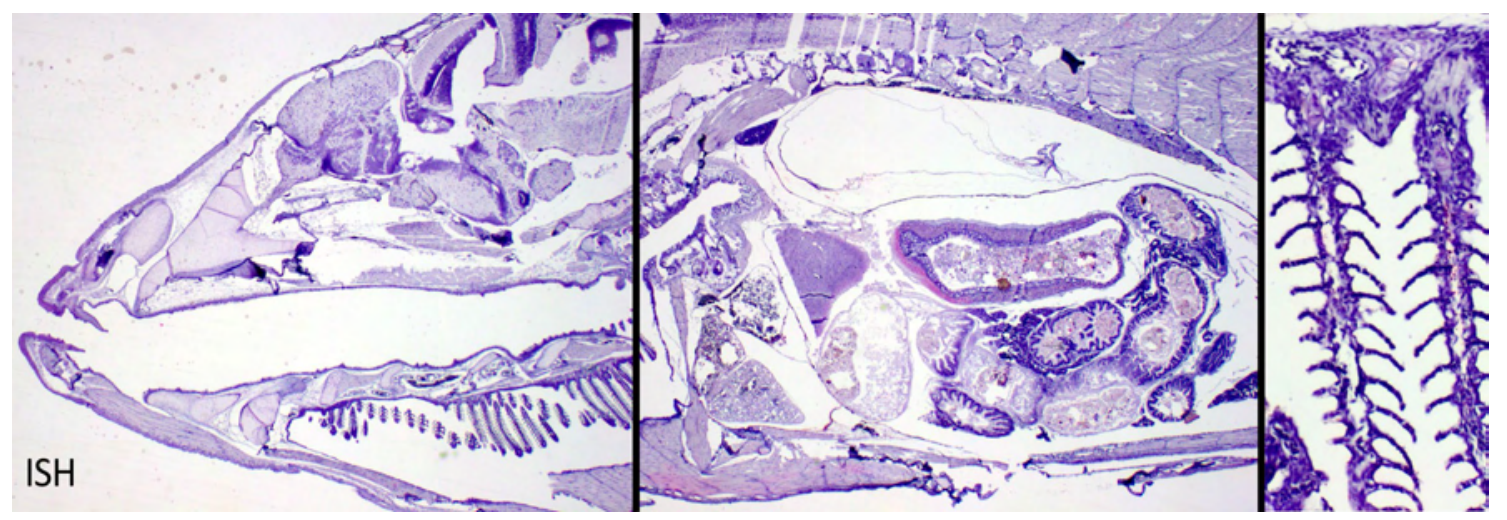

Legenda: Não se observa coloração característica, indicando ausência de Ranavirus nos tecidos. Fonte: Imagem cedida pela Dra. María J. Forzán da Cornell University, EUA. 


\subsection{SEQUENCIAMENTO DE GENOMA VIRAL DE CEPA DE RANAVIRUS}

O sequenciamento molecular (Next Generation Sequencing - NGS) e montagem do genoma de cepa de Ranavirus FV3-like utilizada nas infecções experimentais foram realizados. Após a montagem, obteve-se um genoma contendo 105 kilobases e conteúdo $\mathrm{G}+\mathrm{C}$ de 54,98\%, sendo 94 potenciais ORFs anotadas. A sequência genômica foi depositada no banco de dados GenBank sob o código de acesso MH351268.

\subsection{ANÁLISE FILOGENÉTICA}

A imagem 34 ilustra a reconstrução filogenética de nucleotídeos utilizando sequências genômicas de diferentes espécies de Ranavirus (tabela 5). A amostra sequenciada no presente estudo foi agrupada no clado dos Ranavirus FV3-like, apresentando um valor de bootstrap de 100\% com sequências da mesma espécie viral.

Imagem 34 - Reconstrução filogenética utilizando genomas de todas as diferentes espécies de Ranavirus disponíveis no GenBank.

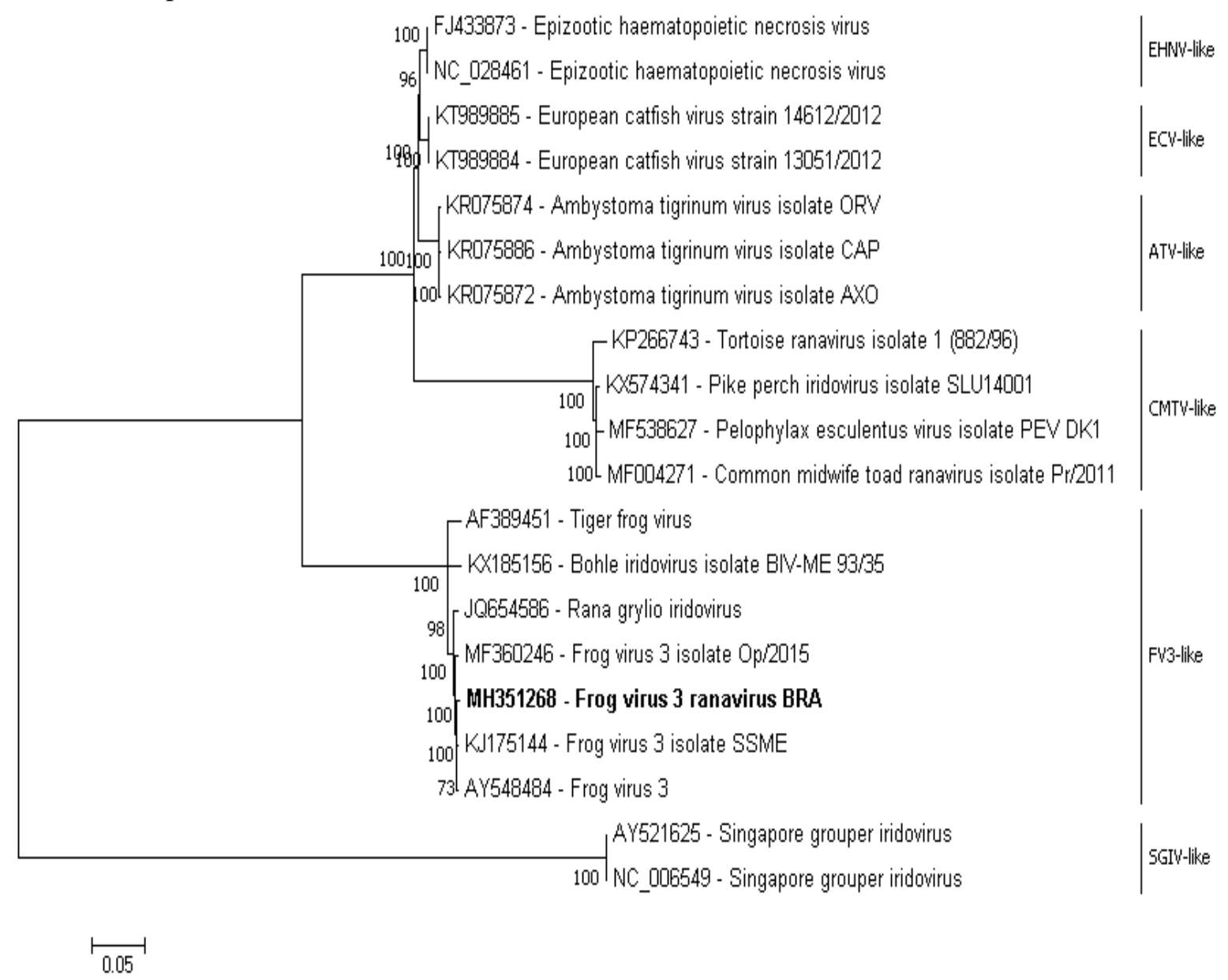

Legenda: Valores de bootstrap superiores a $70 \%$ para 1000 pseudoréplicas são mostrados nos nós. A sequência obtida e analisada no presente estudo é destacada em negrito. Os códigos de acesso das sequências no GenBank são apresentados na árvore. A barra de escala representa a distância filogenética entre sequências.

Fonte: Própria autoria. 


\subsection{ANÁLISE DE IDENTIDADE DO GENE MCP ENTRE DIFERENTES ESPÉCIES DE RANAVIRUS}

Pontuações de identidade de pares de nucleotídeos utilizando sequências completas do gene Major Capsid Protein (MCP) foi superior a 94,00\% entre as diferentes espécies de Ranavirus, exceto para isolados SGIV-like que apresentaram identidade abaixo de 69\% quando comparado a outras espécies (imagem 35).

Imagem 35 - Identidade de sequências nucleotídicas do gene MCP entre diferentes espécies de Ranavirus. As setas em preto indicam a amostra obtida e analisada neste estudo.

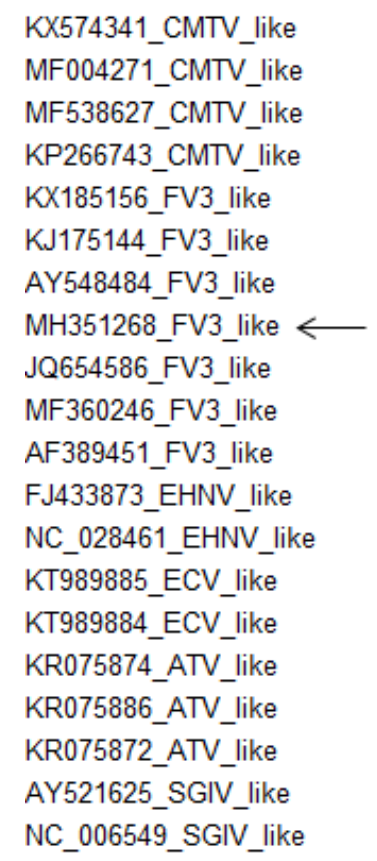

Fonte: Própria autoria.
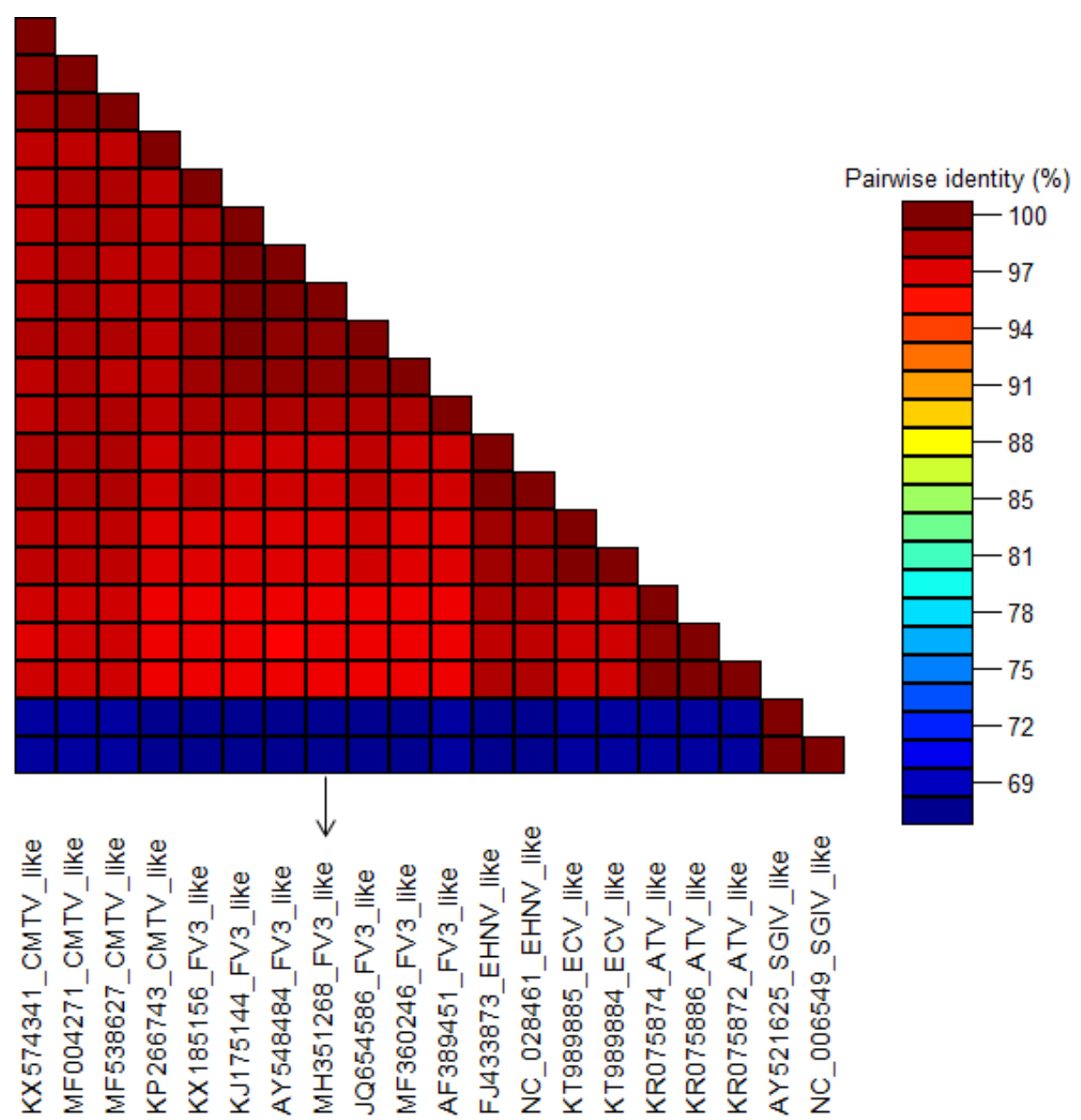
Tabela 7 - Identidade de sequências nucleotídicas (\%) entre genomas de Ranavirus de diferentes espécies.

\begin{tabular}{|c|c|c|c|c|c|c|c|c|c|c|c|c|c|c|c|c|c|c|c|c|}
\hline \multicolumn{21}{|l|}{ Sequence } \\
\hline & МH351268 & KJ175144 & AY548484 & MF360246 & $J Q 654586$ & KX185156 & AF389451 & KP266743 & KX574341 & MF538627 & MF004271 & KR075874 & KR075886 & KR075872 & FJ433873 & NC_02846. & KT989885 & KT989884 & AY521625 & NC_006549 \\
\hline \multicolumn{21}{|c|}{ МH $351268 \leftarrow 100 \% \uparrow$} \\
\hline KJ175144 & $99.26 \%$ & $100 \%$ & & & & & & & & & & & & & & & & & & \\
\hline AY548484 & $99.26 \%$ & $100 \%$ & $100 \%$ & & & & & & & & & & & & & & & & & \\
\hline MF360246 & $98.28 \%$ & $96.79 \%$ & $96.79 \%$ & $100 \%$ & & & & & & & & & & & & & & & & \\
\hline JQ654586 & $98 \%$ & $97.65 \%$ & $97.65 \%$ & $97.82 \%$ & $100 \%$ & & & & & & & & & & & & & & & \\
\hline KX185156 & $94.85 \%$ & $94.98 \%$ & $94.98 \%$ & $95.62 \%$ & $95.26 \%$ & $100 \%$ & & & & & & & & & & & & & & \\
\hline AF389451 & $92.88 \%$ & $93.05 \%$ & $93.05 \%$ & $94.1 \%$ & $93.93 \%$ & $93.53 \%$ & $100 \%$ & & & & & & & & & & & & & \\
\hline KР266743 & $39.24 \%$ & $39.24 \%$ & $39.24 \%$ & $39.36 \%$ & $39.25 \%$ & $39.22 \%$ & $38.27 \%$ & $100 \%$ & & & & & & & & & & & & \\
\hline KX574341 & $39.53 \%$ & $38.45 \%$ & $38.45 \%$ & $38.97 \%$ & $39.28 \%$ & $40 \%$ & $38.19 \%$ & $95.38 \%$ & $100 \%$ & & & & & & & & & & & \\
\hline MF538627 & $39.56 \%$ & $38.67 \%$ & $38.67 \%$ & $38.95 \%$ & $39.3 \%$ & $39.97 \%$ & $38.33 \%$ & $95.84 \%$ & $96.89 \%$ & $100 \%$ & & & & & & & & & & \\
\hline MF004271 & $39.69 \%$ & $38.59 \%$ & $38.59 \%$ & $39.11 \%$ & $39.42 \%$ & $40.16 \%$ & $38.37 \%$ & $96.12 \%$ & $96.47 \%$ & $97.77 \%$ & $100 \%$ & & & & & & & & & \\
\hline KR075874 & $50.49 \%$ & $50.04 \%$ & $50.04 \%$ & $50.81 \%$ & $50.33 \%$ & $51.12 \%$ & $51.94 \%$ & $73.46 \%$ & $74.67 \%$ & $74.37 \%$ & $74.44 \%$ & $100 \%$ & & & & & & & & \\
\hline KR075886 & $50.52 \%$ & $50.07 \%$ & $50.07 \%$ & $50.85 \%$ & $50.35 \%$ & $51.15 \%$ & $51.98 \%$ & $73.45 \%$ & $74.58 \%$ & $74.29 \%$ & $74.38 \%$ & $99.5 \%$ & $100 \%$ & & & & & & & \\
\hline KR075872 & $50.34 \%$ & $50.15 \%$ & $50.15 \%$ & $50.81 \%$ & $50.21 \%$ & $50.93 \%$ & $51.69 \%$ & $73.33 \%$ & $74.81 \%$ & $74.51 \%$ & $74.58 \%$ & $99.5 \%$ & $99.64 \%$ & $100 \%$ & & & & & & \\
\hline FJ433873 & $54.27 \%$ & $44.92 \%$ & $44.92 \%$ & $53.95 \%$ & $54.05 \%$ & $54.9 \%$ & $55.45 \%$ & $80.06 \%$ & $79.53 \%$ & $79.95 \%$ & $79.54 \%$ & $94.43 \%$ & $94.36 \%$ & $94.48 \%$ & $100 \%$ & & & & & \\
\hline NC_028461 & $54.27 \%$ & $44.92 \%$ & $44.92 \%$ & $53.95 \%$ & $54.05 \%$ & $54.9 \%$ & $55.45 \%$ & $80.06 \%$ & $79.53 \%$ & $79.95 \%$ & $79.54 \%$ & $94.43 \%$ & $94.36 \%$ & $94.48 \%$ & $100 \%$ & $100 \%$ & & & & \\
\hline KT989885 & $55.57 \%$ & $45.78 \%$ & $45.78 \%$ & $55.19 \%$ & $55.26 \%$ & $56.17 \%$ & $56.52 \%$ & $78.91 \%$ & $78.41 \%$ & $78.9 \%$ & $78.48 \%$ & $94.07 \%$ & $93.99 \%$ & $94.16 \%$ & $89.68 \%$ & $89.68 \%$ & $100 \%$ & & & \\
\hline KT989884 & $55.58 \%$ & $45.72 \%$ & $45.72 \%$ & $55.19 \%$ & $55.27 \%$ & $56.18 \%$ & $56.53 \%$ & $78.92 \%$ & $78.43 \%$ & $78.91 \%$ & $78.5 \%$ & $94.09 \%$ & $94.01 \%$ & $94.18 \%$ & $89.76 \%$ & $89.76 \%$ & $99.95 \%$ & $100 \%$ & & \\
\hline AY521625 & $36.85 \%$ & $27.64 \%$ & $27.64 \%$ & $36.49 \%$ & $36.67 \%$ & $37.23 \%$ & $37.29 \%$ & $38.35 \%$ & $37.97 \%$ & $38.03 \%$ & $37.83 \%$ & $39.71 \%$ & $39.7 \%$ & $39.75 \%$ & $36.76 \%$ & $36.76 \%$ & $36.59 \%$ & $36.54 \%$ & $100 \%$ & \\
\hline NC_006549 & $36.85 \%$ & $27.64 \%$ & $27.64 \%$ & $36.49 \%$ & $36.67 \%$ & $37.23 \%$ & $37.29 \%$ & $38.35 \%$ & $37.97 \%$ & $38.03 \%$ & $37.83 \%$ & $39.71 \%$ & $39.7 \%$ & $39.75 \%$ & $36.76 \%$ & $36.76 \%$ & $36.59 \%$ & $36.54 \%$ & $100 \%$ & $100 \%$ \\
\hline
\end{tabular}

Legenda: As setas em preto indicam a amostra obtida e analisada neste estudo.

Fonte: Própria autoria. 


\subsection{ANÁLISE DE RECOMBINAÇÃO ENTRE GENOMAS COMPLETOS DE RANAVIRUS FV3-LIKE}

Doze potenciais eventos de recombinação $(p<0,05)$ foram identificados entre a amostra brasileira de FV3-like e amostras de referência (imagem 36).

Imagem 36 - Eventos de recombinação entre a amostra analisada e amostras de referência de Ranavirus FV3-like (continua).
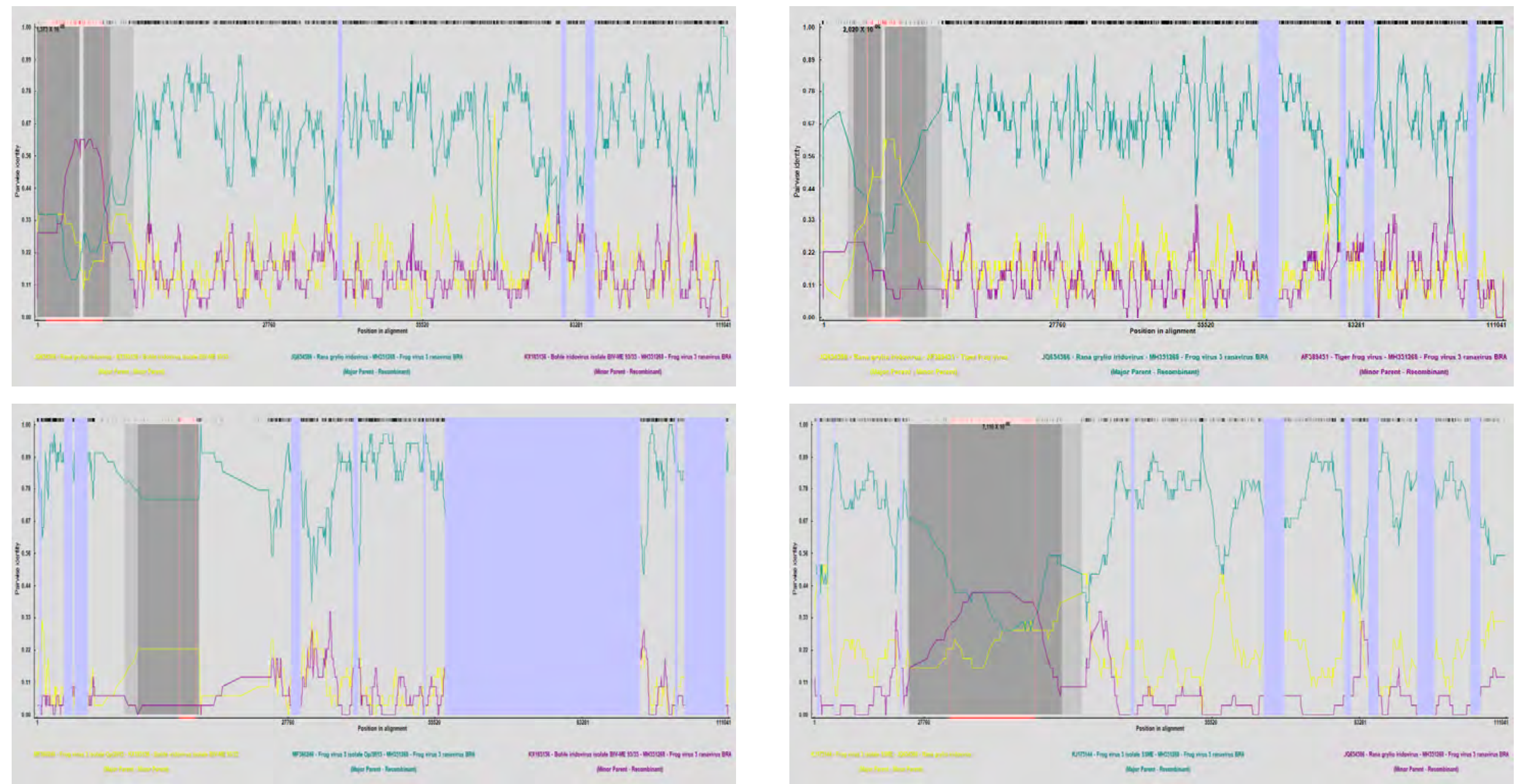
Imagem 36 - Eventos de recombinação entre a amostra analisada e amostras de referência de Ranavirus FV3-like (continuação).
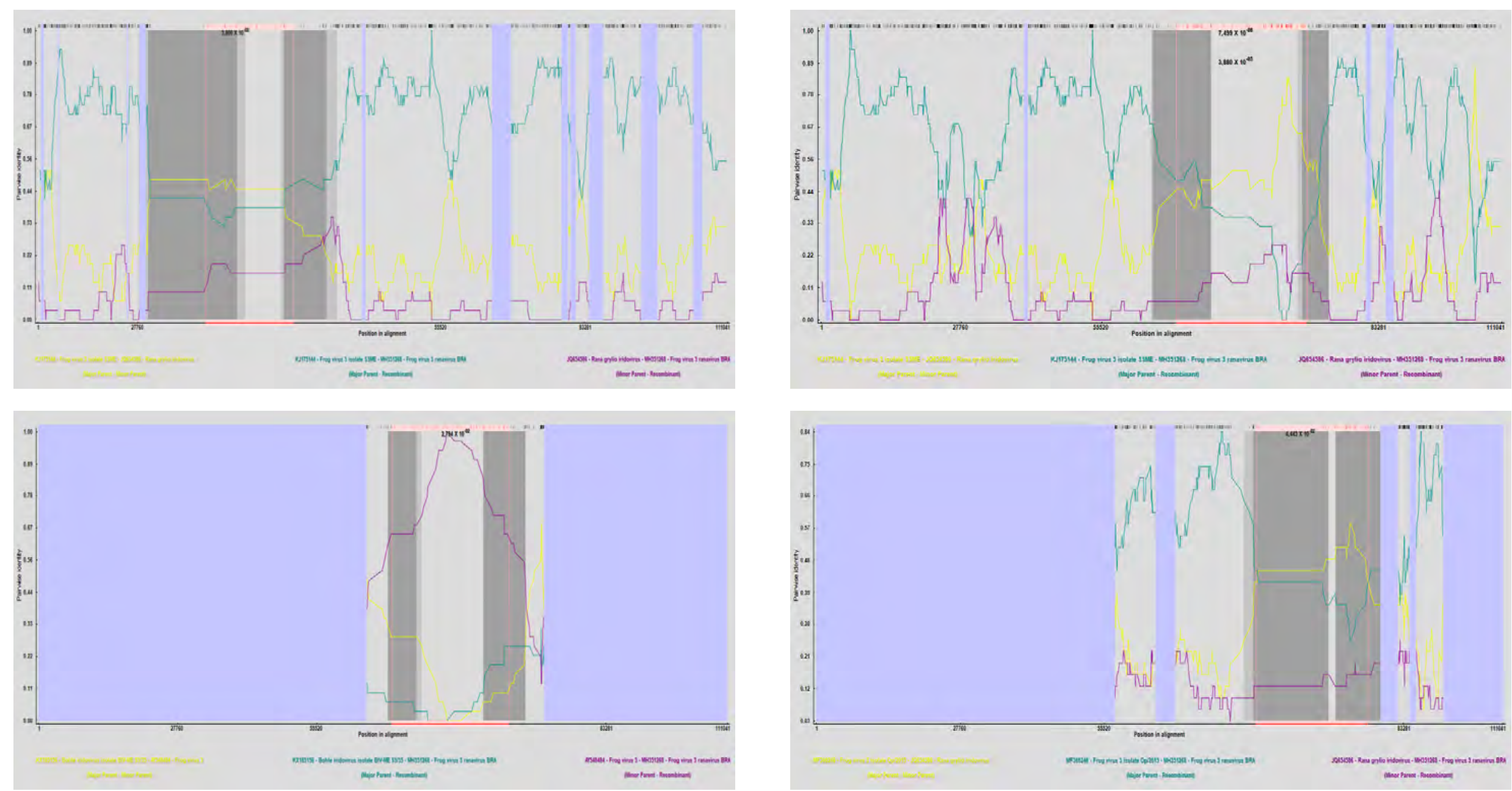
Imagem 36 - Eventos de recombinação entre a amostra analisada e amostras de referência de Ranavirus FV3-like (conclusão).
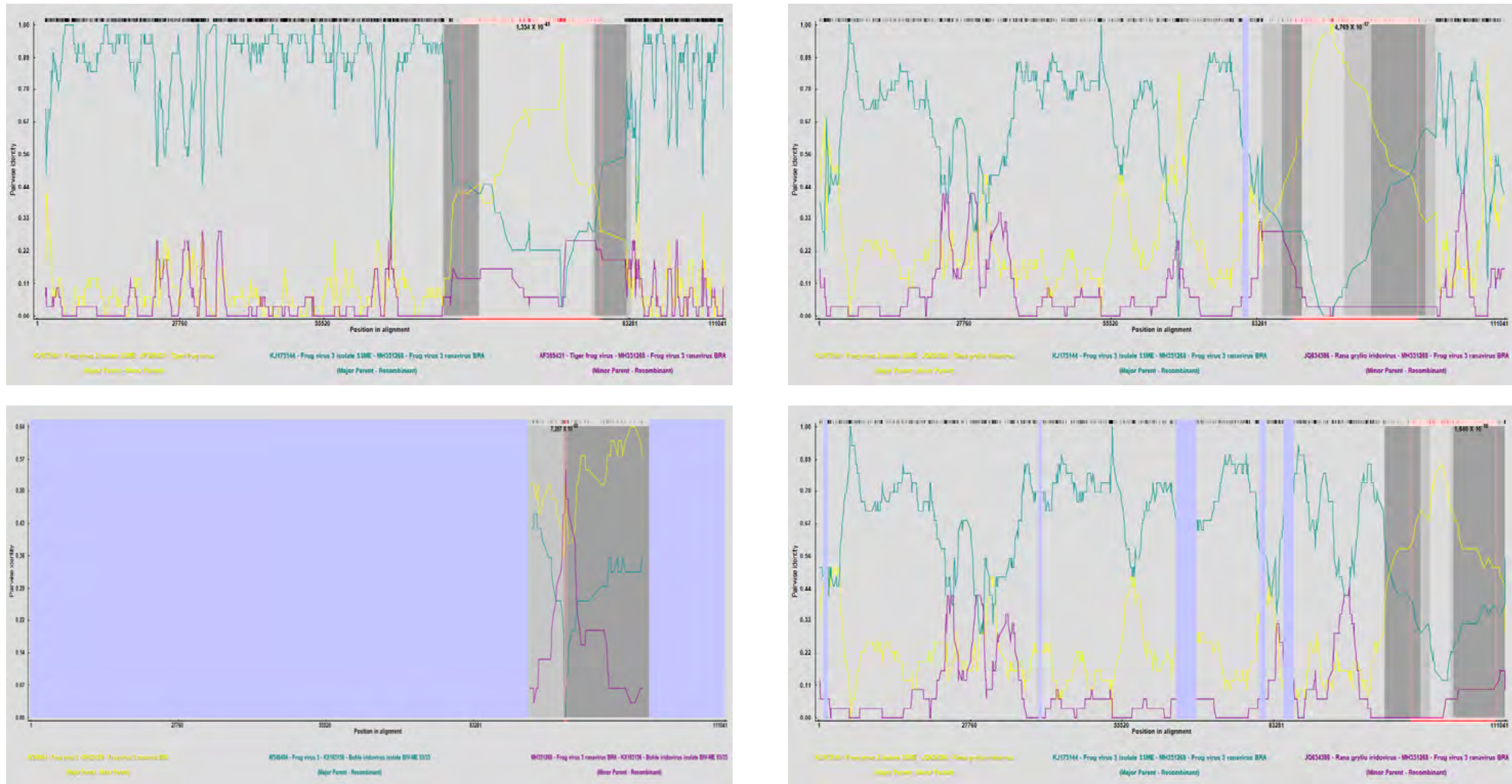

Legenda: Regiões recombinantes são destacadas em vermelho. A descrição das amostras e os códigos de acesso no GenBank são apresentados nos gráficos.

Os gráficos seguem uma sequência crescente, respeitando a disposição do alinhamento das amostras.

Fonte: Própria autoria. 


\section{DISCUSSÃO}

A presente investigação, na perspectiva da avaliação da patogenicidade e caracterização de novos agentes virais em circulação no Brasil, objetivou a realização de infecções experimentais em larvas e alevinos de tilápia do Nilo (Oreochromis niloticus), mundialmente espécie de grande importância zootécnica, utilizando estirpe de Ranavirus FV3-like recentemente detectada e isolada no Brasil, incluindo o sequenciamento e análise do genoma da estirpe viral utilizada.

Os Ranavirus são associados a elevadas taxas de letalidade em vertebrados ectotérmicos de importância ecológica e comercial, desencadeando no hospedeiro doença sistêmica envolvendo múltiplos órgãos. Esses vírus já foram documentados em todos os continentes, infectando pelo menos 175 espécies de vertebrados, incluindo uma grande quantidade de espécies de peixes teleósteos (DUFFUS et al., 2015).

As infecções experimentais nos animais em análise envolveram três diferentes modelos de infecção (injeção intraperitoneal, coabitação e diluição do vírus na água dos tanques) e 4 diferentes concentrações infectantes. Em alevinos, os modelos utilizados foram através de injeção intraperitoneal e coabitação, e em larvas de tilápia do Nilo, o vírus foi diluído diretamente na água dos tanques dos animais.

Macroscopicamente, os alevinos de tilápia desafiados experimentalmente com Ranavirus apresentaram diversos sinais clínicos dentro do período de 60 dias pósinfecção (imagens 6 a 10), análogos aos descritos por Mcgrogan et al. (1998) em relato de caso, no qual 25 tilápias do Nilo foram examinadas devido a altas taxas de mortalidade em decorrência de infecção por iridovirus-like, como por exemplo: exoftalmia, eritema na região submandibular da pele, pigmentação escura na superfície dos animais e palidez do fígado.

Em relação aos resultados das análises sanguíneas em alevinos de tilápia, houve a verificação de hemólise a partir do quarto dia, estendendo-se até o $25^{\circ}$ dia pósinfecção, em animais submetidos à infecção com Ranavirus FV3-like em todas as concentrações infectantes (apêndice - tabela 10). Foi observado expressivo aparecimento de hemácias jovens a partir $12^{\circ}$ dia pós-infecção, indicativo de reposição de células perdidas, porém, com diferenciação acentuada no tamanho e coloração destas células (imagem 13). A média dos volumes das hemácias (VCM) apresentou significância estatística $(p<0,01)$ para os dias pós-infecção e concentrações virais utilizadas, em relação à quantidade média de hemoglobina presente nas hemácias (HCM). Este dado apresentou significância estatística 
para as concentrações virais utilizadas $(p<0,01)$ e dias pós-infecção $(p<0,05)$. Houve também significância estatística $(p<0,05)$ relacionada à proteína plasmática total em relação aos dias pós-infecção, sendo que estes resultados são altamente indicativos de anemia. Achados semelhantes foram reportados por Inouye et al. (1992) em um surto epizoótico ocorrido em uma instalação de cultivo de Pargo-japonês (Pagrus major), no qual os animais apresentaram anemia severa e altos índices de mortalidade, a endemia foi atribuída a iridovírus.

A identificação de linfócitos reativos a partir do quarto dia pós-infecção em alevinos de tilápia do Nilo experimentalmente infectados com Ranavirus FV3-like em concentração $>10^{2} \mathrm{TCID}_{50} / \mathrm{mL}$ e, em 60 dias, em concentração de $10^{1} \mathrm{TCID}_{50} / \mathrm{mL}$, indica resposta a antígeno, sendo que o aparecimento de tais células mais tardiamente em animais infectados, em concentração de $10^{1}$ TCID $50 / \mathrm{mL}$, indica o reconhecimento tardio, possivelmente devido a menor concentração viral utilizada. Em animais do grupo controle, não foram identificados linfócitos reativos (apêndice, tabela 9). Diferentemente dos achados do presente trabalho, Morales et al. (2010) não identificaram linfócitos com morfologia reativa em anfíbios da espécie Xenopus laevis infectados experimentalmente com Ranavirus FV3 utilizando diferentes concentrações virais. Entretanto, um aumento significativo de linfócitos não reativos foi identificado dentro do período de 6 dias pós-infecção em concentração de $1 \times 10^{6}$ plaque-forming units (PFU) de FV3. Em axolote (Ambystoma mexicanum), infectado experimentalmente com Ranavirus da espécie Ambystoma tigrinum vírus (ATV), nenhuma alteração ou quantidade aumentada de linfócitos foram observadas. O vírus ATV é altamente letal para urodelos, sendo que a ausência de resposta adaptativa eficiente nesta ordem de animais pode justificar o resultado obtido (COTTER et al., 2008). Para peixes, em modelo in vivo de infecção ranaviral, não há registros relacionados a alterações referentes aos linfócitos.

Em relação à quantificação das enzimas alanina aminotransferase (ALT) e aspartato aminotransferase (AST), houve significância estatística para o efeito dos dias ( $p<$ 0,05) em enzimas ALT. Porém, para o efeito da concentração viral utilizada e interação concentração/dias pós-infecção, diferenças estatisticamente significantes não foram detectadas. As dosagens de enzimas AST não apresentaram significância estatística com nenhum dos parâmetros analisados em tilápias do Nilo experimentalmente infectadas com FV3. Na bibliografia mundial, são quase nulas as informações associando infecções por Ranavirus em animais de sangue frio e alterações nos níveis das enzimas AST e ALT. Em 
peixes, os níveis destas enzimas são parâmetros importantes para o diagnóstico da função e dano do hepatopâncreas (ZHOU et al., 2014). Em relato de caso envolvendo tartarugas (Terrapene carolina carolina), De Voe et al. (2004) encontraram valores elevados de enzimas AST em 3 de 5 animais naturalmente infectados com Ranavirus. De acordo com as significâncias estatísticas (efeito dos dias em enzimas ALT com $p<0,05$ ), os achados deste estudo indicam que a condição de saúde do fígado dos animais foi afetada no decorrer dos dias do experimento, possivelmente atrelado à infecção experimental por Ranavirus.

Índices organossomáticos, expressos como porcentagem do peso corporal total, são amplamente utilizados na avaliação de saúde em populações de peixes para dar as primeiras indicações de doença (GOEDE; BARTON, 1990). Estes índices permitem a detecção de possíveis hiperplasias (aumento do número de células), hipertrofias (aumento do tamanho das células) ou atrofias (diminuição do tamanho das células) (VAN DYK; PIETERSE; VAN VUREN, 2007). Os índices hepato-somático (IHS) e espleno-somático (IES) representam o percentual de massa do fígado e do baço em relação ao peso corporal, respectivamente. Em alevinos de tilápia do Nilo desafiados experimentalmente com Ranavirus FV3-like no presente trabalho, ambos os índices apresentaram interação (concentração viral utilizada/dias pós-infecção) estatisticamente significante (IHS $=p<0,01$; IES $=p<0,05)$. Na literatura não há informações sobre infecção por Ranavirus e alterações organossomáticas em peixes. Algumas espécies de vírus já demonstraram a capacidade de alteração destes índices em animais infectados, como, por exemplo, o vírus da septicemia hemorrágica viral (VHSV), do gênero Novirhabdovirus. Rehulka (2003) relatou um caso no qual uma grande quantidade de trutas arco-íris (Oncorhynchus mykiss) foram infectadas com VHSV através de transmissão vertical e, em comparação a trutas saudáveis, animais infectados apresentaram índice hepato-somáticos elevados. Reddacliff e Whittington (1996) descreveram alterações derivadas de infecção por Ranavirus EHNV em peixes das espécies Perca fluviatilis L e Oncorhynchus mykiss Walbaum. Dentre os achados, observou-se que os animais doentes apresentavam esplenomegalia e nefromegalia, incluindo focos de palidez no fígado. Os aumentos de volume no baço e rim sugerem hipertrofia e/ou hiperplasia nos animais infectados com EHNV-like, semelhante aos resultados obtidos no presente estudo, onde foram identificados índices espleno-somáticos estatisticamente significantes em alevinos de tilápia do Nilo, experimentalmente infectados com FV3-like.

Este é o primeiro relato associando alterações somáticas em peixes infectados com Ranavirus. 
Resultados estatisticamente significativos associados ao leucograma nos animais submetidos à infecção com Ranavirus não foram encontrados no presente trabalho.

Análises através de PCR convencional visando à amplificação de fragmento do gene MCP de Ranavirus, em animais utilizados no presente trabalho, não apresentaram positividade previamente ou pós-infecção experimental. Resultados falso-negativos em PCR convencional podem ser causados por títulos virais baixos nas amostras analisadas (GRAY; MILLER; HOVERMAN, 2012). Greiner e Gardner (2000) descrevem que a interpretação precisa dos resultados da PCR requer estimativa da sensibilidade e especificidade diagnóstica do ensaio, de modo que os valores preditivos positivo e negativo dos resultados possam ser calculados. Para tanto, uso de controles positivo e negativo adequados são essenciais. Nesse sentido, utilizou-se no presente trabalho controle positivo (Ranavirus FV3-like cultivado em células BF-2 na concentração de $10^{4}$ TCID $50 / \mathrm{mL}$ ) e negativo (água DEPC) em cada reação realizada. Na imagem 21 (fotografia de gel de agarose corado com SYBR ${ }^{\circledR}$ Gold, sob luz UV) é possível observar fragmento amplificado de controle positivo de Ranavirus, enquanto as amostras analisadas mais o controle negativo não apresentaram amplificação. Por outro lado, obteve-se positividade para Ranavirus através de qPCR (imagens 26 e 27) em amplificação de fragmento do gene MCP, seguindo protocolo adaptado de Allender, Bunick e Mitchell (2013) a partir de amostras de larvas de tilápia previamente analisadas por PCR convencional. A qPCR é mais sensível quando comparada a PCR convencional e pode detectar cargas virais mais baixas (PALLISTER et al., 2007; JARAMILLO et al., 2012).

Larvas de tilápia do Nilo desafiadas experimentalmente com Ranavirus apresentaram múltiplas alterações teciduais microscópicas que incluíram: pancreatite aguda, hepatite com áreas necrosadas, túbulos renais vacuolizados e hialinizados, enterite necrótica e descamativa, inúmeros pequenos melanomacrófagos no parênquima hepático e grandes melanomacrófagos na cápsula hepática e no tecido cardíaco, acúmulo de células inflamatórias no hepatopâncreas, autólise em áreas do intestino e do pâncreas, áreas tubulares vacuolizadas hemorrágicas, fibras cardíacas dissociadas, miocardite, rarefação citoplasmática, congestão de vasos sanguíneos, calcificação distrófica, congestão dos vasos centrais acinares pancreáticos e melanocarcinoma na cápsula renal.

Múltiplos sinais clínicos e alterações observadas em hospedeiros com doença ranaviral, descritos na literatura, foram também encontrados em animais submetidos à infecção por FV3 no presente estudo, como por exemplo: degeneração e necrose de tecidos, centros melanomacrófagicos, inclusões intracitoplasmáticas, degeneração de fibras 
musculares, ulceração, hemorragia periocular, exoftalmia, eritema, pigmentação escura e múltiplos focos de palidez no fígado (GRAY; CHINCHAR, 2015; MCGROGAN et al., 1998). Indivíduos que apresentam infecção subclínica ranaviral, podem apresentar alterações histológicas não específicas, tais como vacuolização do epitélio tubular renal e hepatócitos (MILLER; GRAY; STORFER, 2011; ALLENDER et al., 2013).

Imagem 37 - Lesões macroscópicas observadas em peixes com doença ranaviral.


Legenda: A. Esturjão-Pálido (Scaphirhynchus albus) com hemorragia equimótica cutânea (seta) decorrente de infecção por Ranavirus FV3-like. B. Necrose hepática multifocal evidenciada por áreas pálidas no fígado (setas) em Perca fluviatilis infectada com EHNV-like.

Fonte: MILLER et al., 2015.

As lesões causadas em decorrência de ranavirose em peixes, documentadas na imagem 37 (A e B), foram semelhantes às encontradas no presente trabalho (imagem 7 e 
8), no qual tilápias do Nilo foram experimentalmente infectadas por estirpe de Ranavirus FV3-like.

Imagem 38 - Alterações histopatológicas observadas em animais com doença ranaviral em infecções experimentais com Ranavirus FV3-like.
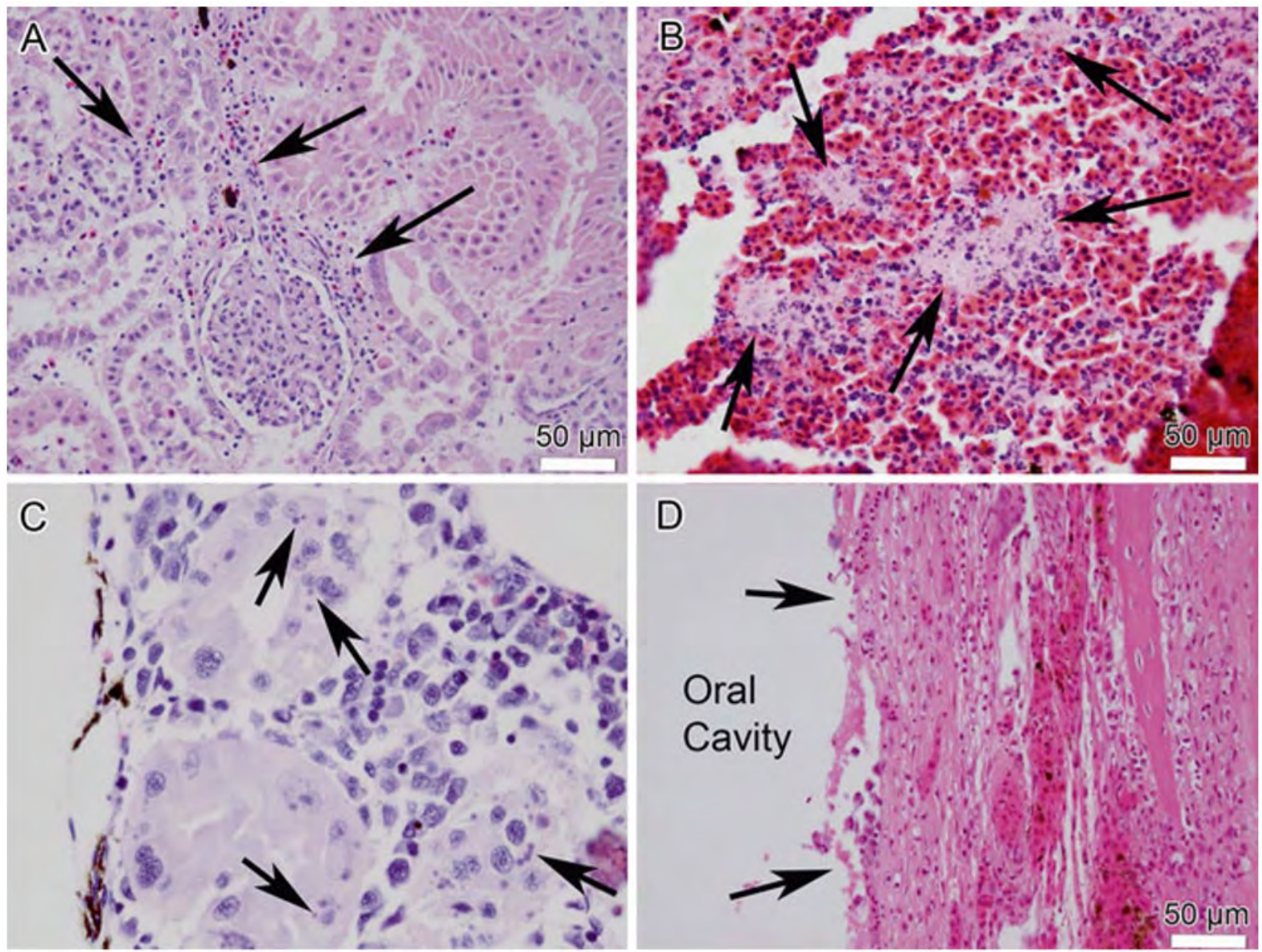

Legenda: A. Necrose renal (setas) em Esturjão-Pálido (Scaphirhynchus albus). B. Necrose do baço (setas) de um sapo da espécie Lithobates sevosus. C. Corpúsculos de inclusão intracitoplasmáticos basofílicos (setas) dentro de células epiteliais tubulares renais de um sapo da espécie Lithobates sphenocephalus. D. Necrose (setas) da mucosa da cavidade oral de tartarugas da espécie Trachemys scripta elegans.

Fonte: MILLER et al., 2015.

Larvas de tilápia do Nilo experimentalmente infectadas com Ranavirus FV3-like no presente estudo apresentaram alterações histopatológicas semelhantes às reportadas na imagem 38 em anfíbios, peixes e répteis; estas alterações incluíram regiões do tecido hepático necrosadas (imagem 30) e corpúsculos de inclusão basofílicos (imagem 28), característicos de infecção por Ranavirus.

Corpúsculos de inclusão basofílicos são encontrados com certa facilidade através de exames histológicos em hospedeiros infectados com Ranavirus; vários trabalhos já reportaram a presença destas estruturas em tecidos de animais infectados (REDDACLIFF; 
WHITTINGTON, 1996; ALLENDER et al., 2013; BAYLEY; HILL; FEIST, 2013; WALTZEK et al., 2014).

Imagem 39 - Histopatologia em rã da espécie Lithobates catesbeianus infectada com Ranavirus.

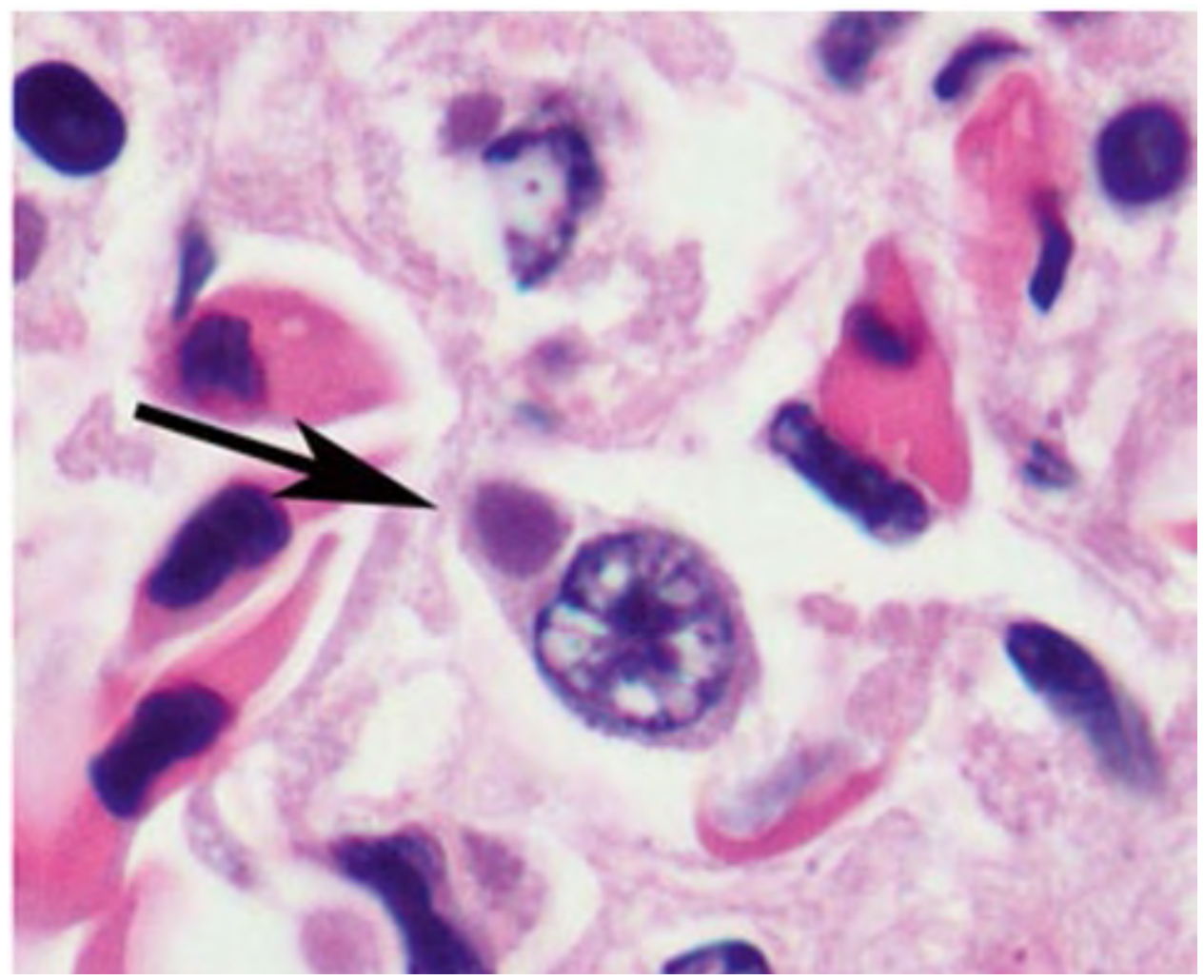

Legenda: As secções histológicas do animal revelaram corpúsculos de inclusão intracitoplasmáticos raros, altamente sugestivos de infecção por Ranavirus.

Fonte: MILLER et al., 2015.

Em larvas de tilápia do Nilo experimentalmente infectadas com Ranavirus no presente trabalho, foram identificados corpúsculos de inclusão intracitoplasmáticos raros (imagem 28 - B), altamente sugestivos de infecção por ranavírus, muito semelhantes ao reportado em rã da espécie Lithobates catesbeianus (imagem 39).

É interessante destacar a observação de áreas inflamadas no tecido cardíaco de larva de tilápia submetida à infecção por Ranavirus FV3-like, em concentração de $10^{3}$ TCID $_{50} / \mathrm{mL}$ (imagem 31) no presente trabalho. Além das inflamações presentes neste órgão, são observadas estruturas sugestivas de corpúsculos de inclusão basofílicos e uma grande quantidade de eosinófilos e centros melanomacrófagos ao redor destas inclusões, indicando uma reação de defesa contra estruturas virais anexas às células cardíacas (imagem 29). Fibras cardíacas dissociadas (indicando degeneração de tecido muscular) também foram observadas 
no tecido coronário de animais infectados experimentalmente com Ranavirus FV3-like no presente estudo (imagem 29).

Técnicas imuno-histoquímicas (IHC) e de hibridização in situ (ISH) são úteis para detecção de determinados vírus. Na IHC, alguns antissoros são direcionados contra proteínas oriundas de genes conservados de um determinado gênero viral, sendo reativos de forma cruzada (como é o caso dos Ranavirus, utilizando o anticorpo anti-EHNV). Desta forma, diferentes espécies do gênero Ranavirus podem ser detectadas através desta técnica, porém, não é possível a distinção entre espécies. A utilização da técnica de IHC para Ranavirus é efetivamente utilizada em anfíbios, mas não há relatos da utilização desse método em peixes. Alguns trabalhos sugerem que pode haver diferenças nos resultados de IHC entre diferentes isolados de Ranavirus e entre os hospedeiros (MILLER et al., 2015). No presente trabalho, não foram evidenciadas partículas virais através de análises imuno-histoquímicas em larvas de tilápia do Nilo decorrentes de infecção experimental por Ranavirus FV3-like, sendo que apenas dois animais infectados com Ranavirus, utilizando concentração de $10^{4}$ TCID $50 / \mathrm{mL}$, dias 3 e 10 pós-infecção experimental, foram analisados imunohistoquimicamente, devido à utilização de reagente de alto custo para a realização da técnica. Assim, optou-se por testar somente duas das amostras, em concentrações maiores, em uma fase inicial; caso se observasse positividade, o restante das amostras seria analisado na sequência. Em ambos os exemplares examinados, a coloração vermelha generalizada esteve presente; entretanto, após a inserção do anticorpo anti-EHNV, a falta de especificidade e forte coloração das células do muco comprovaram uma inespecífica coloração de artefatos de fundo (imagem 32). Levando a uma intensa coloração inespecífica, a coloração IHC padronizada para Ranavirus infectando anfíbios parece não funcionar com tilápias do Nilo. Em um trabalho recente, analisando rãs do gênero Pelophylax, Saucedo et al. (2018) não encontraram positividade para Ranavirus através das técnicas de PCR e IHC, apesar dos animais analisados apresentarem vários sinais de infecção pelo vírus, incluindo a presença de corpúsculos de inclusão citoplasmáticos e necrose em diferentes tecidos. Nesse estudo, 13 isolados de Ranavirus, coletados de dez diferentes regiões na Holanda, tiveram o genoma sequenciado, sendo identificados perfis genômicos de três diferentes grupos de CMTV-like presentes em áreas distintas do país.

A técnica de ISH é utilizada para a identificação de presença viral em tecido infectado, com o emprego de sondas moleculares que localizam sequências específicas de ácido nucléico dentro de seções de tecido fixas (MILLER et al., 2015). São poucos os relatos 
da utilização desta técnica em animais infectados com Ranavirus. No presente trabalho, optou-se por utilizar os mesmos animais analisados através da técnica de IHC, e os mesmos critérios de amostragem. A ausência de coloração com a sonda ISH para Ranavirus sugere que a coloração IHC era um artefato de fundo, indicando assim que não há evidências de Ranavirus nos tecidos dos animais analisados no projeto (imagem 33). Na literatura, são nulos os relatos de peixes infectados com FV3 positivos através da técnica de ISH. Relato da utilização da técnica de ISH em peixes marinhos da espécie Epinephelus malabaricus infectados com Ranavirus SGIV foi descrito por Huang et al. (2004), no qual o rim e baço dos animais apresentaram coloração específica para a infecção viral.

Acreditamos que as técnicas de IHC e ISH devam ser aprimoradas para uma maior sensibilidade na detecção de FV3 em peixes de importância comercial e/ou ecológicos.

Para a caracterização do genoma de estirpe brasileira de Ranavirus FV3-like utilizada nos processos de infecção experimental, realizou-se o sequenciamento genético completo, através de sequenciamento de nova geração (NGS), no sistema Illumina ${ }^{\circledR}$ MiSeq. Após a montagem e identificação das fases de leitura aberta (ORFs), obteve-se um genoma contendo 105 kilobases e 54,98\% de guanina (G) + citosina (C), sendo 94 potenciais ORFs anotadas. A quantidade de nucleotídeos, porcentagem de $\mathrm{G}+\mathrm{C}$ e número de ORFs do genoma analisado estão de acordo com os descritos na literatura para o vírus genotipado (JANCOVICH et al., 2012; TAN et al., 2004). A sequência genômica derivada do presente trabalho foi depositada em banco mundial de genes (GenBank), sob o código de acesso: MH351268.

Dezenove sequências genômicas de membros da família Iridoviridae, representando todas as espécies de Ranavirus que possuem o genoma disponível, foram recuperadas do GenBank para a realização de caracterização filogenética, análises de identidade e detecção de recombinação do genoma entre estirpe brasileira de Ranavirus FV3 e sequências genômicas de referência.

A reconstrução filogenética nucleotídica agrupou a estirpe brasileira de Ranavirus no clado dos FV3-like, apresentando valor de bootstrap de 100\% com amostras genômicas da mesma espécie viral. De modo intrigante, a amostra KX185156, derivada de Ranavirus da espécie Bohle iridovirus (BIV), adentrou o clado dos FV3-like apresentando $\geq$ 98\% de valor de bootstrap. O BIV foi a espécie viral causadora de surto epizoótico com mortalidade de $100 \%$ de tilápias em cativeiro da espécie Oreochromis mossambicus, dentro de um período de 60 dias na Austrália, reportado por Ariel e Owens (1997). Semelhante a este 
trabalho, outros trabalhos recentes também demonstraram a inserção dos BIV no clado dos

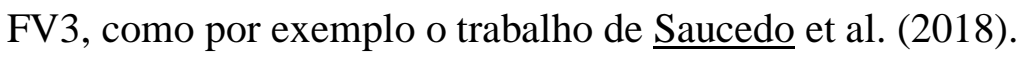

Pontuações de identidade de nucleotídeos entre genomas de diferentes espécies de Ranavirus demonstraram que a estirpe brasileira analisada apresentou a maior identidade (99,26\%) com isolados norte-americanos de FV3-like (KJ175144 e AY548484), e apenas 36,85\% com isolados de Ranavirus SGIV-like (AY521625 e NC_006549). A identidade comparativa entre o genoma em análise e a amostra KX185156, espécie Bohle iridovirus, foi de $94,85 \%$, uma porcentagem relativamente alta por se tratar de uma diferente espécie dentro do mesmo gênero viral. A média geral de identidade entre genomas foi de $62,01 \%$.

Quando analisadas as sequências nucleotídicas completas do gene MCP (1392pb) de diferentes espécies de Ranavirus, a identidade entre elas foi superior a 94,00\%, excetuando-se para isolados SGIV-like, que apresentaram identidade abaixo de 69\% comparado a outras espécies dentro do mesmo gênero. Resultados semelhantes foram descritos por Waltzek et al. (2014), comparando sequências nucleotídicas do gene MCP entre as espécies SGIV-like e FV3-like isolado de esturjão (Scaphirhynchus albus). A porcentagem de identidade entre amostras foi de 69,4\% e entre o FV3-like isolado e demais espécies de Ranavirus (FV3, BIV, CMTV, EHNV, ECV e ATV), a identidade para o gene foi $>94,1 \%$.

Abordagens mais sensíveis, rápidas e universais para a identificação e classificação de novos Ranavirus derivam de informações sobre sequências genômicas disponíveis, a partir de uma variedade de isolados. Utilizado amplamente como região alvo para o rastreamento rápido de Ranavirus, a análise do gene MCP é altamente indicada, porém, por se tratar de um gene conservado dentro das diferentes espécies que caracterizam o gênero, a diferenciação entre estirpes virais pode ficar limitada, dado o alto grau de identidade entre elas, e esta característica pode levar a resultados epidemiológicos inadequados, assim como inadequações de programas de translocação de espécies selvagens que requeiram a detecção e diferenciação de diferentes estirpes de Ranavirus, entre diferentes localidades, considerando as populações de origem e destino (JANCOVICH et al., 2015). Nestes casos, a caracterização individual do gene MCP se torna limitada, pois, excetuando-se os Ranavirus SGIV-like, as demais espécies apresentam identidade do gene superior a 94,00\% entre as diferentes espécies.

Através da aquisição de genes via recombinação, membros de famílias virais que apresentam dsDNA se adaptam a seus respectivos hospedeiros (TIDONA; DARAI, 
2000). Eventos de recombinação são reconhecidos como forças motrizes na geração de vírus patogênicos (GONZÁLEZ-CANDELAS; LÓPEZ-LABRADOR; BRACHO, 2011; DING et al., 2017). No presente trabalho, foram identificados 12 potenciais eventos de recombinação em diferentes regiões do genoma, estatisticamente significantes $(p<0,05)$, entre a estirpe brasileira de Ranavirus e amostras de referência de FV3-like, as quais apresentaram $>90 \%$ de identidade entre amostras. Todas as amostras de referência utilizadas para a realização da análise (JQ654586, KX185156, AF389451, MF360246, KJ175144 e AY548484) apresentaram eventos de recombinação com a amostra brasileira de Ranavirus FV3-like em alguma região do genoma. Três eventos recombinantes, envolvendo 2298pb, foram identificados entre a amostra analisada neste estudo e a amostra Bohle iridovirus (KX185156). Quanto às amostras de FV3-like da América do Norte, KJ175144 e AY548484, identificaram-se seis e dois eventos recombinantes, respectivamente (imagem 36). Vários estudos têm identificado eventos de recombinação que ocorrem naturalmente entre isolados de Ranavirus (ABRAMS et al., 2013; EPSTEIN; STORFER, 2016). Claytor et al. (2017) reportaram eventos de recombinação entre Ranavirus das espécies FV3-like e CMTV-like derivando no surgimento de estirpe ranaviral altamente patogênica infectando anfíbios. Neste estudo, cepas isoladas de uma mesma instalação comercial em diferentes anos (1998 e 2006) foram analisadas, sugerindo-se que a evolução do vírus tenha ocorrido no local e sendo possível que um ou mais genes do vírus CMTV-like tenham sido rearranjados através de processos de recombinação.

Técnicas de recombinação in vitro de Ranavirus tem sido utilizada para gerar cepas mutantes, visando a substituição de genes específicos em marcadores selecionáveis (CHEN et al., 2011; ANDINO et al., 2015).

Os achados referentes a análise genômica indicam que estirpe brasileira de FV-3 e, provavelmente outras estirpes de FV-3 já detectadas, apresentam eventos de recombinação com genoma de Bohle iridovirus, corroborando o agrupamento dessas estirpes num mesmo clado. Filogeneticamente, amostra BIV-like (KX185156) também se agrupou no clado dos FV3-like, apresentando identidade para o gene MCP > 97\% e 94,85\% de identidade do genoma com a amostra brasileira de Ranavirus FV3-like. Além disso, foram identificados 3 eventos de recombinação com a amostra em estudo. Vale ressaltar que Ranavirus Bohle iridovirus foi a única espécie confirmadamente responsável por evento epizoótico em tilápias (Oreochromis mossambicus), associado a altas taxas de mortalidade (ARIEL; OWENS, 1997). 
Em síntese, os resultados do presente trabalho contribuem para o melhor entendimento da infecção causada por estirpe brasileira de Ranavirus FV3 em tilápia do Nilo (Oreochromis niloticus), espécie globalmente produzida e comercializada. Além disso, adiciona e reforça a potencial recombinação entre diferentes estirpes de Ranavirus, contribuindo para uma melhor compreensão das características etiológicas e epidemiológicas de Ranavirus circulantes no Brasil e no mundo. 


\section{CONCLUSÕES}

- Larvas e alevinos de tilápia do Nilo (Oreochromis niloticus) foram infectados experimentalmente com estirpe brasileira de Ranavirus Frog virus 3-like, através de 3 diferentes modelos de infecção (injeção intraperitoneal, coabitação e diluição do vírus nas águas dos animais).

- Alevinos de tilápia do Nilo desafiados com cepa brasileira de FV3-like apresentaram vários sinais clínicos macroscópicos, semelhantes aos descritos na literatura, característicos de ranavirose.

- Hemólise a partir do quarto dia pós-infecção experimental com FV3-like e reposição de hemácias apresentando anisocitose e policromasia a partir do $12^{\circ}$ dia pós-infecção em alevinos de tilápia do Nilo submetidos à infecção por FV-3-like foram observados. Valores estatisticamente significantes $(p<0,05)$ relacionados aos dias pós-infecção e concentrações virais utilizadas, para a média dos volumes das hemácias (VCM) e quantidade média de hemoglobina presente nas hemácias (HCM) foram observados nos animais desafiados, indicando anemia e hemorragia nos animais analisados, característicos de infecção ranaviral.

- Linfócitos reativos, indicando resposta a antígenos, foram identificados em alevinos de tilápia desafiados com Ranavirus FV3-like em todas as concentrações virais utilizadas.

- Houve diferença estatística significante para o efeito dos dias $(p<0,05)$ em enzimas alanina aminotransferase (ALT), indicativo de que as condições de saúde do fígado dos animais foram alteradas no decorrer do período do experimento, possivelmente vinculadas a infecção experimental por Ranavirus.

- Relações organossomáticas apresentando interações estatisticamente significantes pertinentes aos índices hepato-somático $(p<0,01)$ e espleno-somático $(p<0,05)$ foram obtidas em tilápias do Nilo experimentalmente infectadas com estirpe brasileira de Ranavirus FV-3. 
- Detecção de Ranavirus através de PCR convencional em animais submetidos à infecção experimental por esse agente (larvas e alevinos de tilápia do Nilo) apresentaram resultados negativo, provavelmente derivados da baixa quantidade de vírus presente nos tecidos dos animais e também da sensibilidade da técnica. Por outro lado, utilizando qPCR com $c t<35$, técnica com sensibilidade analítica maior, amostras de larvas de tilápia foram positivas.

- Múltiplas alterações teciduais microscópicas, características de ranavirose foram identificadas em tecidos de larvas de tilápia do Nilo, infectadas experimentalmente com estirpe brasileira de FV3-like.

- Corpúsculos de inclusão basofílicos, típicos de hospedeiros infectados com Ranavirus, foram identificados através de exames histopatológicos em larvas de tilápia do Nilo infectadas experimentalmente com estirpe brasileira de FV3-like, diferentemente das amostras oriundas dos animais do grupo controle.

- Fibras cardíacas dissociadas, inflamação no tecido cardíaco e identificação de corpúsculos de inclusão anexos às células cardíacas, com uma grande quantidade de eosinófilos e centros melanomacrófagos ao redor destas inclusões, indicando uma reação de defesa, foram observados em larvas de tilápia do Nilo infectadas experimentalmente com estirpe brasileira de FV3-like.

- Técnicas imuno-histoquímica (IHC) e de hibridização in situ (ISH) apresentaram resultados negativos em tecidos de larvas de tilápia do Nilo infectadas experimentalmente com estirpe brasileira de Ranavirus FV3-like em concentração de $10^{4} \mathrm{TCID}_{50} / \mathrm{mL}$.

- O genoma da estirpe brasileira de Ranavirus FV3-like utilizada nos processos de infecção experimental em tilápias do Nilo (Oreochromis niloticus) apresentou 105 kilobases, contendo 54,98\% de guanina (G) + citosina (C), sendo que 94 potenciais ORFs foram anotadas. 
- Reconstrução filogenética, baseada em sequencias nucleotídicas agrupou a amostra brasileira de Ranavirus no clado dos Frog virus 3-like, apresentando valores de bootstrap de 100\% com outras amostras genômicas da mesma espécie viral.

- A estirpe brasileira de Ranavirus apresentou maior identidade genômica com estirpes norte-americanas de FV3.

- Doze potenciais eventos de recombinação, estatisticamente significantes $(p<0,05)$, foram identificados entre a estirpe brasileira de FV3-like e amostras de referência desse genótipo, adicionando e reforçando a potencial recombinação dentro de Ranavirus. 


\section{REFERÊNCIAS}

ABRAMS, A. J. et al. Recent host-shifts in ranaviruses: signatures of positive selection in the viral genome. Journal of General Virology, Society for General Microbiology, United Kingdom, v. 94, pt. 9, p. 2082-2093, 2013.

ALENCAR, A. L. F. Isolamento e caracterização de estirpe de Frog Virus 3-símile detectada em rãs-touro gigante (Lithobates catesbeianus) no Estado de São Paulo. 2016. 61 f. Dissertação (Mestrado) - Faculdade de Zootecnia e Engenharia de Alimentos, Universidade de São Paulo, Pirassununga, 2016.

ALIZON, S. et al. Virulence evolution and the trade-off hypothesis: history, current state of affairs and the future. Journal of Evolutionary Biology, Blackwell Publishing Inc., United Kingdom, v. 22, n. 2, p. 245-259, 2009.

ALLENDER, M. C. et al. Pathogenicity of frog virus 3-like virus in red-eared slider turtles (Trachemys scripta elegans) at two environmental temperatures. Journal of Comparative Pathology, W. B. Saunders Co., Ltd., United Kingdom, v. 149, n. 2-3, p. 356-367, 2013.

ALLENDER, M. C.; BUNICK, D.; MITCHELL, M. A. Development and validation of TaqMan quantitative PCR for detection of frog virus 3-like virus in eastern box turtles (Terrapene carolina carolina). Journal of Virological Methods, Elsevier BV, Netherlands, v. 188, n. 1-2, p. 121-125, 2013.

ALMEIDA-QUEIROZ, S. R. et al. Molecular detection and phylogenetic relationships of an amphibian Ranavirus associated to outbreaks of mortality in Brazilian fish farm. Virus Reviews \& Research, v. 19, supl. 2, p. 58-59, 2014.

ANDINO, F. D. J. et al. Characterization of frog virus 3 knockout mutants lacking putative virulence genes. Virology, Elsevier Inc., United States, v. 485, p. 162-170, 2015.

ANTIA, R.; LEVIN, B. R.; MAY, R. M. Within-host population dynamics and the evolution and maintenance of microparasite virulence. American Naturalist, The University of Chicago Press, United States, v. 144, n. 3, p. 457-472, 1994.

ANUÁRIO PeixeBR da Piscicultura. Brasil é o $4^{\mathbf{0}}$ maior produtor mundial de Tilápia: País produziu 357 mil t em 2017, superando Filipinas e Tailândia. p. 12-14, 2018.

ARIEL, E. et al. Comparative study of ranavirus isolates from cod (Gadus morhua) and turbot (Psetta maxima) with reference to other ranaviruses. Archives of Virology, Springer Verlag, Germany, v. 155, n. 8, p. 1261-1271, 2010.

ARIEL, E.; OWENS, L. Epizootic mortalities in tilapia Oreochromis mossambicus. Diseases of Aquatic Organisms, Inter-Research Science Publishing, Germany, v. 29, n. 1, p. 1-6, 1997. 
BAYLEY, A. E.; HILL, B. J.; FEIST, S. W. Susceptibility of the European common frog Rana temporaria to a panel of ranavirus isolates from fish and amphibian hosts. Diseases of Aquatic Organisms, Inter-Research Science Publishing, Germany, v. 103, n. 3, p. 171-183, 2013.

BIRGEL, E. H. Hematologia clínica veterinária. In: Conferência anual da sociedade paulista de medicina veterinária, São Paulo, 1982. p. 50.

BOONTHAI, T. et al. Laboratory investigation into the role of largemouth bass virus (Ranavirus, Iridoviridae) in smallmouth bass mortality events in Pennsylvania rivers. BMC Veterinary Research, in press, 2018.

BRASIL. Portal Brasil. 2014, 2015. Disponível em: <http://www.brasil.gov.br>. Acesso em: 11 out. 2018.

BRUNNER, J. L.; RICHARDS, K.; COLLINS, J. P. Dose and host characteristics influence virulence of ranavirus infections. Oecologia, Springer Verlag, Germany, v. 144, n. 3, p. 399406, 2005.

BRUNNER, J. L.; SCHOCK, D. M.; COLLINS, J. P. Transmission dynamics of the amphibian ranavirus Ambystoma tigrinum virus. Diseases of Aquatic Organisms, InterResearch Science Publishing, Germany, v. 77, n. 2, p. 87-95, 2007.

BULL, J. J. Perspective: virulence. Evolution; international journal of organic evolution, Wiley-Blackwell, United States, v. 48, n. 5, p. 1423-1437, 1994.

CAMPBELL, T. W. Hematology. In: RITCHIE, B.W.; HARRISON, G. J.; HARRISON L. R. (eds). Avian Medicine: Principles and Application. Lake Worth: Wingers Publishing, 1994. p. 176-198.

CARAGUEL, C. G. B. et al. Selection of a cutoff value for real-time polymerase chain reaction results to fit a diagnostic purpose: analytical and epidemiologic approaches. Journal of Veterinary Diagnostic Investigation, SAGE Publications Inc., United States, v. 23, n. 1, p. 2-15, 2011.

CARDOSO, A. L. S. P.; TESSARI, E. N. C. Estudo dos parâmetros hematológicos em frangos de corte. Arquivos do Instituto Biológico, Brasil, v. 70, p. 419-424, 2003.

CHEN, G. et al. Improved knockout methodology reveals that Frog Virus 3 mutants lacking either the $18 \mathrm{~K}$ immediate-early gene or the truncated $v I F-2 \alpha$ gene are defective for replication and growth in vivo. Journal of Virology, American Society for Microbiology, United States, v. 85, n. 21, p. 11131-11138, 2011.

CHINCHAR, V. G. et al. Family Iridoviridae: Poor Viral Relations No Longer. Current Topics in Microbiology and Immunology, Springer Verlag, Germany, v. 328, p. 123-170, 2009. 
CHINCHAR, V. G. Ranaviruses (family Iridoviridae): emerging cold-blooded killers. Archives of Virology, Springer Verlag, Germany, v. 147, n. 3, p. 447-470, 2002.

CLAYTOR, S. C. et al. Ranavirus phylogenomics: Signatures of recombination and inversions among bullfrog ranaculture isolates. Virology, Elsevier Inc., United States, v. 511, p. 330-343, 2017.

COTTER, J. D. et al. Transcriptional response of Mexican axolotls to Ambystoma tigrinum virus (ATV) infection. BMC Genomics, BioMed Central, United Kingdom, v. 9, p. 1-19, 2008.

DASZAK, P.; CUNNINGHAM, A. A.; HYATT, A. D. Emerging infectious diseases of wildlife - threats to biodiversity and human health. Science, American Association for the Advancement of Science, United States, v. 287, p. 443-449, 2000.

DE ROODE, J. C. et al. Virulence and competitive ability in genetically diverse malaria infections. Proceedings of the National Academy of Sciences of the United States of America, National Academy of Sciences, United States, v. 102, n. 21, p. 7624-7628, 2005.

DE VOE, R. et al. Ranavirus-associated morbidity and mortality in a group of captive eastern box turtles (Terrapene carolina carolina). Journal of Zoo and Wildlife Medicine, American Association of Zoo Veterinarians, United States, v. 35, n. 4, p. 534-543, 2004.

DING, N. Z. et al. A permanent host shift of rabies virus from Chiroptera to Carnivora associated with recombination. Scientific Reports, Nature Publishing Group, United Kingdom, v. 7, n. 1, p. 1-9, 2017.

DUFFUS, A. L. J. et al. Distribution and host range of ranaviruses. In: GRAY, M. J.; CHINCHAR, V. G. (eds). Ranaviruses: lethal pathogens of ectothermic vertebrates. $1^{\text {st }}$ ed. Springer, International Publishing, 2015. p. 9-57.

EATON, H. E. et al. Comparative genomic analysis of the family Iridoviridae: re-annotating and defining the core set of iridovirus genes. Virology Journal, BioMed Central, United Kingdom, v. 4, n. 11, 2007.

EATON, H. E.; RING, B. A.; BRUNETTI, C. R. The genomic diversity and phylogenetic relationship in the family Iridoviridae. Viruses, Multidisciplinary Digital Publishing Institute (MDPI), Switzerland, v. 2, n. 7, p. 1458-1475, 2010.

EL-SAYED, A. F. M. Tilapia culture basic biology and ecology. In: Tilapia Culture. ed. by CABI Publishing, 2006, p. 25-33.

EPSTEIN, B.; STORFER, A. Comparative genomics of an emerging amphibian virus. G3: Genes, Genomes, Genetics, Genetics Society of America, United States, v. 6, n. 1, p. 15-27, 2016. 
ESCOLA SUPERIOR DE AGRICULTURA "LUIZ DE QUEIROZ" UNIVERSIDADE DE SÃO PAULO (ESALQ). 2016. Disponível em: < http://www.esalq.usp.br>. Acesso em: 12 set. 2018.

FOOD AND AGRICULTURE ORGANIZATION (FAO). 2000, 2012, 2014, 2017.

Disponível em: <http://www.fao.org>. Acesso em: 15 out. 2018.

FU, X. et al. The pathogenicity and biological features of Santee-Cooper Ranaviruses isolated from Chinese perch and snakehead fish. Microbial Pathogenesis, Elsevier BV, Netherlands, v. 112, p. 269-273, 2017.

GALLI, L. et al. Ranavirus detection by PCR in cultured tadpoles (Rana catesbeiana Shaw, 1802) from South America. Aquaculture, Elsevier BV, Netherlands, v. 257, n. 1-4, p. 78-82, 2006.

GOEDE, R. W.; BARTON, B. A. Organismic indices and an autopsy-based assessment as indicators of health and condition in fish. In: ADAM, S. M. (eds). Biological Indicators of Stress in Fish. $8^{\text {th }}$ ed. American Fisheries Society, Bethesda, MD, 1990. p. 93-108.

GONZÁLEZ-CANDELAS, F.; LÓPEZ-LABRADOR, F. X.; BRACHO, M. A. Recombination in hepatitis $C$ virus. Viruses, Multidisciplinary Digital Publishing Institute (MDPI), Switzerland, v. 3, n. 10, p. 2006-2024, 2011.

GRAY, M. J.; CHINCHAR, V. G. Ranaviruses: Lethal Pathogens of Ectothermic Vertebrates. 1st ed. Springer, International Publishing, 2015.

GRAY, M. J.; MILLER, D. L.; HOVERMAN, J. T. Ecology and pathology of amphibian ranaviruses. Diseases of Aquatic Organisms, Inter-Research Science Publishing, Germany, v. 87, n. 3, p. 243-266, 2009.

GRAY, M. J.; MILLER, D. L.; HOVERMAN, J. T. Reliability of non-lethal surveillance methods for detecting ranavirus infection. Diseases of Aquatic Organisms, Inter-Research Science Publishing, Germany, v. 99, n. 1, p. 1-6, 2012.

GREINER, M.; GARDNER, I. A. Epidemiologic issues in the validation of veterinary diagnostic tests. Preventive Veterinary Medicine, Elsevier BV, Netherlands, v. 45, n. 1-2, p. 3-22, 2000.

HOVERMAN, J. T. et al. Phylogeny, life history, and ecology contribute to differences in amphibian susceptibility to ranaviruses. EcoHealth, Springer Verlag, Germany, v. 8, n. 3, p. 301-319, 2011. 
HUANG, C. et al. In situ hybridization of a marine fish virus, Singapore grouper iridovirus with a nucleic acid probe of major capsid protein. Journal of Virological Methods, Elsevier BV, Netherlands, v. 117, n. 2, p. 123-128, 2004.

HUANG, S. M. et al. Genetic analysis of fish iridoviruses isolated in Taiwan during 20012009. Archives of Virology, Springer Verlag, Germany, v. 156, n. 9, p. 1505-1515, 2011.

HYATT, A. D. et. al. Comparative studies of piscine and amphibian iridoviruses. Archives of Virology, Springer Verlag, Germany, v. 145, n. 2, p. 301-331, 2000.

INOUYE, K. et al. Iridovirus Infection of Cultured Red Sea Bream, Pagrus major. Fish Pathology, Japanese Society of Fish Pathalogy, Japan, v. 27, n. 1, p. 19-27, 1992.

INSTITUTO BRASILEIRO DE GEOGRAFIA E ESTATÍSTICA (IBGE). Aquicultura. Prod. Pec. Munic., 42:23-26, 2014. Disponível em:

$<$ http://biblioteca.ibge.gov.br/visualizacao/periodicos/84/ppm_2014_v42_br.pdf $>$. Acesso em: 06 out. 2018.

JANCOVICH, J. K. et al. Family Iridoviridae. In: KING, A. M. Q.; ADAMS, M. J.; CARSTENS, E. B.; LEFKOWITZ, E. J. (eds). Virus taxonomy: classification and nomenclature of viruses. Ninth report of the International Committee on Taxonomy of Viruses. Elsevier, Amsterdam, 2012. p. 193-210.

JANCOVICH, J. K. et al. Ranavirus replication: molecular, cellular, and immunological events. In: GRAY, M. J.; CHINCHAR, V. G. (eds). Ranaviruses: lethal pathogens of ectothermic vertebrates. $1^{\text {st }}$ ed. Springer, International Publishing, 2015. p. 114-139.

JANCOVICH, J. K.; STECKLER, N.; WALTZEK, T. B. Ranavirus taxonomy and phylogeny. In: GRAY, M. J.; CHINCHAR, V. G. (eds). Ranaviruses: lethal pathogens of ectothermic vertebrates. $1^{\text {st }}$ ed. Springer, International Publishing, 2015. p. 59-70.

JARAMILLO, D. et al. A validated quantitative polymerase chain reaction assay for the detection of ranaviruses (Family Iridoviridae) in fish tissue and cell cultures, using EHNV as a model. Aquaculture, Elsevier BV, Netherlands, v. 356, p. 186-192, 2012.

JOHNSON, A. J. et al. Ranavirus infection of free-ranging and captive box turtles and tortoises in the United States. Journal of Wildlife Diseases, Wildlife Disease Association, United States, v. 44, n. 4, p. 851-863, 2008.

KATOH, K.; ROZEWICKI, J.; YAMADA, K. D. MAFFT online service: multiple sequence alignment, interactive sequence choice and visualization. Briefings in Bioinformatics, Oxford University Press, United Kingdom, in press, 2017.

KENWARD, M. G.; ROGER, J. H. Small Sample Inference for Fixed Effects from Restricted Maximum Likelihood. Biometrics, Blackwell Publishing Inc., United Kingdom, v. 53, n. 3, p. 983-997, 1997. 
KRUSKAL, W. H.; WALLIS, W. A. Use of Ranks in One-Criterion Variance Analysis. Journal of the American Statistical Association, Taylor \& Francis, United Kingdom, v. 47, n. 260, p. 583-621, 1952.

KUBISTA, M. et al. The Real-Time Polymerase Chain Reaction. Molecular Aspects of Medicine, Elsevier Ltd., United Kingdom, v. 27, n. 2-3, p. 95-125, 2006.

KUBITZA, F. Aquicultura no Brasil, conquistas e desafios. Panorama da Aquicultura, Brasil, v. 25, n. 150, p. 10-11, 2015.

. Nutrição e saúde no cultivo de tilápias. Panorama da Aquicultura, Brasil, v. 23, n. 137, p. 14-23, 2013.

. O mar está prá peixe... ...prá peixe cultivado. Panorama da Aquicultura, Brasil, v. 17, n. 100, p. 14-23, 2007.

. Transporte de peixes vivos - Parte I. Panorama da Aquicultura, Brasil, v. 7, n. 43, p. 20-26, 1997.

KUROBE, T. et al. Iridovirus Infections among Missouri River Sturgeon: Initial Characterization, Transmission, and Evidence for Establishment of a Carrier State. Journal of Aquatic Animal Health, Taylor \& Francis, United Kingdom, v. 23, n. 1, p. 9-18, 2011.

LANGDON, J. S. Experimental transmission and pathogenicity of epizootic haematopoietic necrosis virus (EHNV) in redfin perch, Perca fluviatilis L., and 11 other teleosts. Journal of Fish Diseases, Blackwell Publishing Inc., United Kingdom, v. 12, n. 4, p. 295-310, 1989.

LANZAROT, M. P. et al. Hematologic, protein electrophoresis, biochemistry, and cholinesterase values of free-living black stork nestlings (Ciconia nigra). Journal of Wildlife Diseases, Wildlife Disease Association, United States, v. 41, n. 2, p. 379-386, 2005.

LEVENE, H. Robust Test for Equality of Variances. In: OLKIN, I. et al. (eds).

Contributions to Probability and Statistics: Essays in Honor of Harold Hotteling. $1^{\text {st }}$ ed. Stanford University Press, California, 1960. p. 278-292.

LOVSHIN, L. L. Tilapia Aquaculture in Brazil. In: COSTA-PIERCE, B. A.; RAKOCY, J. E. (eds.). Tilapia aquaculture in the Americas 2. Baton Rouge: The World Aquaculture Society, 2000. p. 133-140.

MAO, J. et al. Molecular characterization of iridoviruses isolated from sympatric amphibians and fish. Virus Research, Elsevier BV, Netherlands, v. 63, n. 1-2, p. 45-52, 1999.

MARTIN, D. P. et al. RDP4: detection and analysis of recombination patterns in virus genomes. Virus Evolution, Oxford University Press, United Kingdom, v. 1, n. 1, vev003, 2015.

MAZZONI, R. et al. Mass mortality associated with a frog virus 3-like Ranavirus infection in farmed tadpoles Rana catesbeiana from Brazil. Diseases of Aquatic Organisms, InterResearch Science Publishing, Germany, v. 86, n. 3, p. 181-191, 2009. 
MCGROGAN, D. G. et al. Systemic disease involving an iridovirus-like agent in cultured tilapia, Oreochromis niloticus L. - a case report. Journal of Fish Diseases, Blackwell Publishing Inc. United Kingdom, v. 21, n. 2, p. 149-152, 1998.

MILLER, D. L. et al. Comparative Pathology of Ranaviruses and Diagnostic Techniques. In: GRAY, M. J.; CHINCHAR, V. G. (eds). Ranaviruses: lethal pathogens of ectothermic vertebrates. $1^{\text {st }}$ ed. Springer, International Publishing, 2015. p. 171-208.

MILLER, D.; GRAY, M.; STORFER, A. Ecopathology of ranaviruses infecting amphibians. Viruses, Multidisciplinary Digital Publishing Institute (MDPI), Switzerland, v. 3, n. 11, p. 2351-2373, 2011.

MORALES, H. D. et al. Innate Immune Responses and Permissiveness to Ranavirus Infection of Peritoneal Leukocytes in the Frog Xenopus laevis. Journal of Virology, American Society for Microbiology, United States, v. 84, n. 10, p. 4912-4922, 2010.

MORRISON, E. A. et al. Complete genome analysis of a frog virus 3 (FV3) isolate and sequence comparison with isolates of differing levels of virulence. Virology Journal, BioMed Central, United Kingdom, v. 11, n. 46, 2014.

MUHIRE, B. M.; VARSANI, A.; MARTIN, D. P. SDT: A Virus Classification Tool Based on Pairwise Sequence Alignment and Identity Calculation. PLoS ONE, Public Library of Science, United States, v. 9, n. 9, e108277, 2014.

MUTEIA, H. FAO no Brasil Memória de Cooperação Técnica. 2009. Disponível em: < https://www.fao.org.br/download/LivroFAOBrasilMemoriaCooperacaoTecnica.pdf $>$. Acesso em: 6 jun. 2018.

NAKAJIMA, K.; MAENO, Y. Pathogenicity of red sea bream iridovirus and other fish iridoviruses to red sea bream. Fish Pathology, Japanese Society of Fish Pathalogy, Japan, v. 33, n. 3, p. 143-144, 1998.

NATT M. P.; HERRICK C. A. A New Blood Diluent for Counting the Erythrocytes and Leucocytes of the Chicken. Poultry Science, Oxford University Press, United States, v. 31, n. 4, p. 735-738, 1952.

NOGA, E. J. Iridoviral diseases. In: . Fish Disease: Diagnosis and Treatment. $2^{\text {nd }}$ ed. Ames US-IA: Wiley-Blackwell, 2010. cap. 84, p. 287-289.

ORGANIZAÇÃO PARA A COOPERAÇÃO E DESENVOLVIMENTO ECONÔMICO (OCDE). 2017. Disponível em: <https://www.oecd-ilibrary.org>. Acesso em: 20 out. 2018.

PALLISTER, J. et al. Development of real-time PCR assays for the detection and differentiation of Australian and European ranaviruses. Journal of Fish Diseases, Blackwell Publishing Inc., United Kingdom, v. 30, n. 7, p. 427-438, 2007. 
QUENTEL, C.; OBACH, A. The cellular composition of the blood and haematopoietic organs of turbot Scophthalmus maximus L. Journal of Fish Biology, Blackwell Publishing Inc., United Kingdom, v. 41, n. 5, p. 709-716, 1992.

REDDACLIFF, L. A.; WHITTINGTON, R. J. Pathology of epizootic haematopoietic necrosis virus (EHNV) infection in rainbow trout (Oncorhynchus mykiss Walbaum) and redfin perch (Perca fluviatilis $L$ ). Journal of Comparative Pathology, W. B. Saunders Co., Ltd., United Kingdom, v. 115, n. 2, p. 103-115, 1996.

REED, L. J.; MUENCH, H. A simple method of estimating fifty percent endpoints.

American Journal of Epidemiology, Oxford University Press, United Kingdom, v. 27, n. 3, p. 493-497, 1938.

REHULKA, J. Haematological analyses in rainbow trout Oncorhynchus mykiss affected by viral haemorrhagic septicaemia (VHS). Diseases of Aquatic Organisms, Inter-Research Science Publishing, Germany, v. 56, n. 3, p. 185-193, 2003.

SAUCEDO, B. et al. Ranavirus genotypes in the Netherlands and their potential association with virulence in water frogs (Pelophylax spp.). Emerging Microbes \& Infections, Nature Publishing Group, United Kingdom, v. 7, n. 1, p. 1-14, 2018.

SHAPIRO, S. S.; WILK, M. B. An Analysis of Variance Test for Normality (Complete Samples). Biometrika, Oxford University Press, United Kingdom, v. 52, n. 3/4, p. 591-611, 1965.

SIVASANKAR, P. et al. Characterization of a virulent ranavirus isolated from marine ornamental fish in India. VirusDisease, Springer, India, v. 28, n. 4, p. 373-382, 2017.

STORFER, A. et al. Phylogenetic concordance analysis shows an emerging pathogen is novel and endemic. Ecology Letters, Blackwell Publishing Inc., United Kingdom, v. 10, n. 11, p. 1075-1083, 2007.

TAMURA, K. et al. MEGA6: Molecular Evolutionary Genetics Analysis version 6.0. Molecular Biology and Evolution, Oxford University Press, United Kingdom, v. 30, n. 12, p. 2725-2729, 2013.

TAN, W. G. H. et al. Comparative genomic analyses of frog virus 3, type species of the genus Ranavirus (family Iridoviridae). Virology, Elsevier Inc., United States, v. 323, n. 1, p. 70-84, 2004.

TIDONA, C. A.; DARAI, G. Iridovirus homologues of cellular genes - Implications for the molecular evolution of arge DNA viruses. Virus Genes, Kluwer Academic Publishers, Netherlands, v. 21, n. 1-2, p. 77-81, 2000. 
TOO, H. P. Real time PCR quantification of GFR $\alpha-2$ alternatively spliced isoforms in murine brain and peripheral tissues. Molecular Brain Research, Elsevier BV, Netherlands, v. 114, n. 2, p. 146-153, 2003.

VAN DYK, J. C.; PIETERSE, G. M.; VAN VUREN, J. H. J. Histological changes in the liver of Oreochromis mossambicus (Cichlidae) after exposure to cadmium and zinc. Ecotoxicology and Environmental Safety, Elsevier Inc., United States, v. 66, n. 3, p. 432-440, 2007.

WALTZEK, T. B. et al. New disease records for hatchery-reared sturgeon. I. Expansion of frog virus 3 host range into Scaphirhynchus albus. Diseases of Aquatic Organisms, InterResearch Science Publishing, Germany, v. 111, n. 3, p. 219-227, 2014.

WHITTINGTON, R. J. et al. Spread of epizootic haematopoietic necrosis virus (EHNV) in redfin perch (Perca fluviatilis) in southern Australia. Australian Veterinary Journal, WileyBlackwell, United States, v. 73, n. 3, p. 112-114, 1996.

WHITTINGTON, R. J.; BECKER, J. A.; DENNIS, M. M. Iridovirus infections in finfish critical review with emphasis on ranaviruses. Journal of Fish Diseases, Blackwell Publishing Inc., United Kingdom, v. 33, n. 2, p. 95-122, 2010.

WHITTINGTON, R. J.; REDDACLIFF, G. L. Influence of environmental temperature on experimental infection of redfin perch (Perca fluviatilis) and rainbow-trout (Oncorhynchus mykiss) with Epizootic Hematopoietic Necrosis Virus, an Australian iridovirus. Australian Veterinary Journal, Wiley-Blackwell, United States, v. 72, n. 11, p. 421-424, 1995.

WILLIAMS, T.; BARBOSA-SOLOMIEU, V.; CHINCHAR, V. G. A decade of advances in iridovirus research. Advances in Virus Research, Elsevier Inc., United States, v. 65, p. 173248, 2005.

WOODLAND, J. E.; NOYES, A. D.; GRIZZLE, J. M. A survey to detect largemouth bass virus among fish from Hatcheries in the Southeastern USA. Transactions of the American Fisheries Society, Taylor \& Francis, United Kingdom, v. 131, n. 2, p. 308-311, 2002.

WORLD ORGANISATION FOR ANIMAL HEALTH (OIE). 2014, 2017. Disponível em: $<$ http://www.oie.int>. Acesso em: 26 set. 2018.

WURTS, W. A. Using salt to reduce handling stress in channel catfish. World Aquaculture, v. 26, n. 3, p. 80-81, 1995.

ZHOU, C. et al. Effect of dietary carbohydrate on non-specific immune response, hepatic antioxidative abilities and disease resistance of juvenile golden pompano (Trachinotus ovatus). Fish and Shellfish Immunology, Elsevier Inc., United States, v. 41, n. 2, p. $183-$ 190, 2014. 


\section{APÊNDICE}

Tabela 8 - Resultados de eritrograma e proteína plasmática total (continua).

\begin{tabular}{|c|c|c|c|c|c|c|c|c|c|}
\hline $\begin{array}{l}\text { Dia Pós- } \\
\text { Infecção }\end{array}$ & Animal & $\begin{array}{c}\text { Eritrócitos } \\
(/ \mu \mathrm{L})\end{array}$ & $\begin{array}{c}\text { Hemoglobina } \\
\text { (g/dL) }\end{array}$ & $\begin{array}{c}\text { Hematócrito } \\
(\%)\end{array}$ & VCM (fL) & HCM (pg) & $\begin{array}{c}\text { CHCM } \\
(\%)\end{array}$ & $\begin{array}{c}\text { Proteína } \\
\text { Total } \\
\text { Plasmática } \\
\text { (g/dL) }\end{array}$ & OBS \\
\hline \multirow{7}{*}{$\begin{array}{c}+ \\
\dot{0} \\
\frac{\pi}{0}\end{array}$} & $\begin{array}{c}\text { Controle } \\
\text { Negativo } 1\end{array}$ & 964800 & 5,6 & 29 & 300,6 & 58,0 & 19,3 & 3 & - \\
\hline & $10^{1} 1$ & 924600 & 5,8 & 27 & 292,0 & 62,7 & 21,5 & 3 & Hemólise (+) \\
\hline & $10^{2} 1$ & 1577850 & 5,5 & 30 & 190,1 & 34,9 & 18,3 & 2,8 & - \\
\hline & $10^{2} 2$ & 1427100 & 6,4 & 29 & 203,2 & 44,8 & 22,1 & 3,2 & Coágulo \\
\hline & $10^{3} 1$ & 1537650 & 3,4 & 20 & 130,1 & 22,1 & 17,0 & 2,2 & - \\
\hline & $10^{3} 2$ & 2311500 & 5,5 & 26 & 112,5 & 23,8 & 21,2 & 3,8 & Hemólise + \\
\hline & $10^{4} 1$ & 1085400 & 4,0 & 21 & 193,5 & 36,9 & 19,0 & 2,2 & - \\
\hline \multirow{4}{*}{ 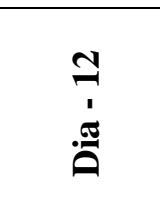 } & $10^{1} 1$ & 1256250 & 4,3 & 19 & 151,2 & 34,2 & 22,6 & 3,2 & - \\
\hline & $10^{1} 2$ & 1778850 & 5,4 & 24 & 134,9 & 30,4 & 22,5 & 3,2 & - \\
\hline & $10^{2} 1$ & 934650 & 5,8 & 26 & 278,2 & 62,1 & 22,3 & 4,0 & - \\
\hline & $10^{3} 2$ & 964800 & 6,3 & 22 & 228,0 & 65,3 & 28,6 & 3,6 & - \\
\hline \multirow{7}{*}{$\begin{array}{l}\stackrel{\infty}{-} \\
\dot{\sigma} \\
\stackrel{0}{0}\end{array}$} & $\begin{array}{c}\text { Controle } \\
\text { Negativo } 1\end{array}$ & 934650 & 5,4 & 25 & 267,5 & 57,8 & 21,6 & 4,4 & - \\
\hline & $10^{1} 1$ & 944700 & 6,2 & 23 & 243,5 & 65,6 & 27,0 & 5,0 & Hemólise +++ \\
\hline & $10^{2} 1$ & 1547700 & 4,5 & 19 & 122,8 & 29,1 & 23,7 & 4,6 & - \\
\hline & $10^{2} 2$ & 1346700 & 6,5 & 26 & 193,1 & 48,3 & 25,0 & 5,0 & Hemólise +++ \\
\hline & $10^{3} 2$ & 1567800 & 6,7 & 29 & 185,0 & 42,7 & 23,1 & 4,0 & - \\
\hline & $10^{4} 1$ & 1427100 & 6,3 & 30 & 210,2 & 44,1 & 21,0 & 4,8 & - \\
\hline & $10^{4} 2$ & 1105500 & 5,4 & 25 & 226,1 & 48,8 & 21,6 & 4,0 & - \\
\hline
\end{tabular}


Tabela 8 - Resultados de eritrograma e proteína plasmática total (conclusão).

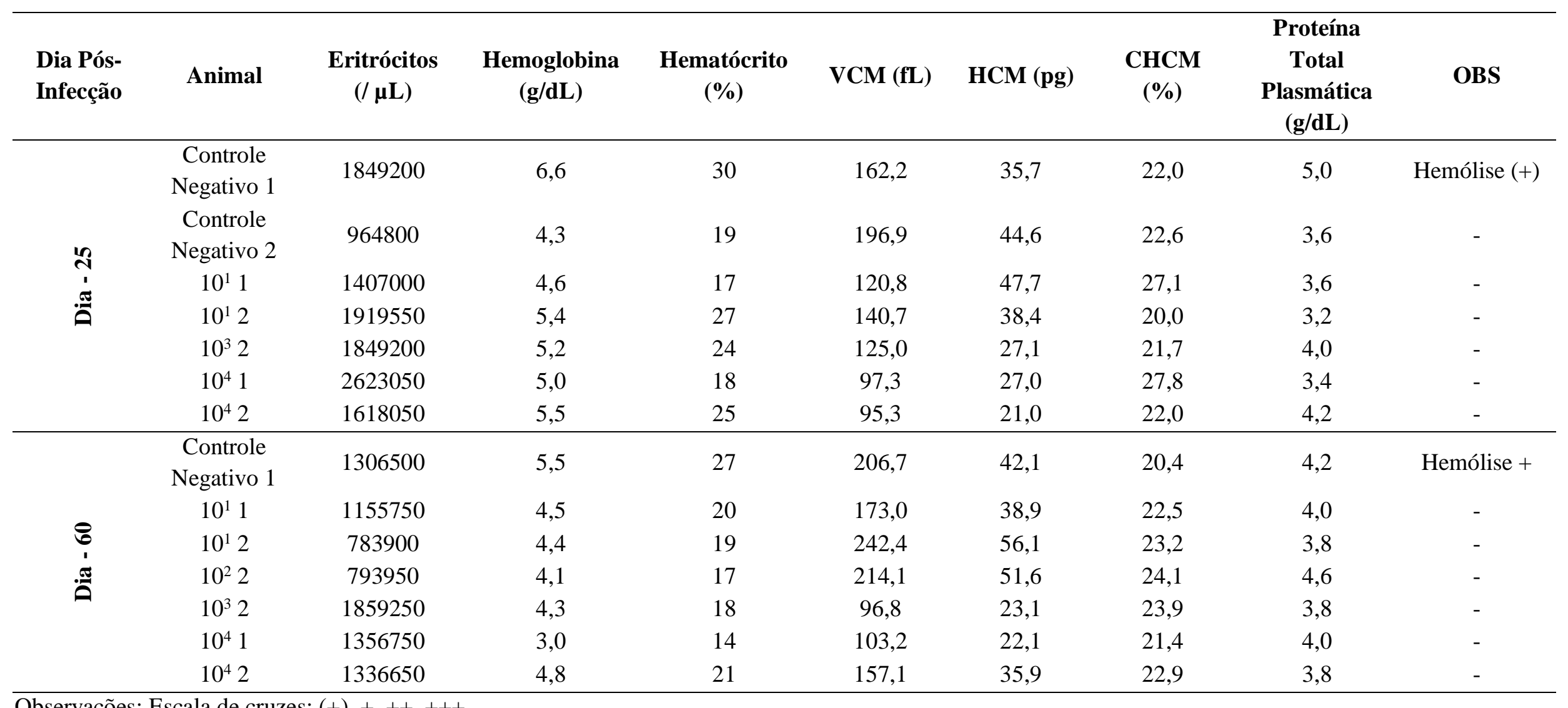

Observações: Escala de cruzes: $(+),+,++,+++$.

Eritrócitos policromáticos $(+)$ em grande parte dos animais.

Trombócitos agregados em grande parte dos animais.

Fonte: Própria autoria. 


\begin{tabular}{|c|c|c|c|c|c|c|c|c|c|c|c|c|c|}
\hline \multirow[b]{2}{*}{$\begin{array}{l}\text { Dia Pós- } \\
\text { Infecção }\end{array}$} & \multirow[b]{2}{*}{ Animal } & \multirow[b]{2}{*}{$\begin{array}{l}\text { Leucócito } \\
\text { s }(/ \mu \mathrm{L})\end{array}$} & \multicolumn{5}{|c|}{ Leucócitos Relativos (\%) } & \multicolumn{5}{|c|}{ 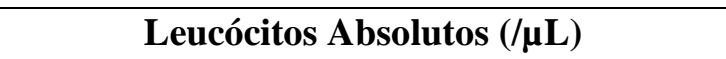 } & \multirow[b]{2}{*}{ OBS } \\
\hline & & & $\begin{array}{l}\text { Neutr } \\
\text { ófilos }\end{array}$ & $\begin{array}{l}\text { Linfóc } \\
\text { itos }\end{array}$ & $\begin{array}{l}\text { Monóc } \\
\text { itos }\end{array}$ & $\begin{array}{c}\text { Eosinó } \\
\text { filos }\end{array}$ & $\begin{array}{c}\text { Basófil } \\
\text { os }\end{array}$ & $\begin{array}{l}\text { Neutr } \\
\text { ófilos }\end{array}$ & $\begin{array}{c}\text { Linfóc } \\
\text { itos }\end{array}$ & $\begin{array}{l}\text { Monóc } \\
\text { itos }\end{array}$ & $\begin{array}{c}\text { Eosinó } \\
\text { filos }\end{array}$ & $\begin{array}{c}\text { Basófil } \\
\text { os }\end{array}$ & \\
\hline \multirow{7}{*}{ 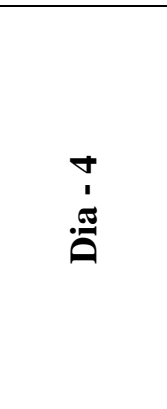 } & $\begin{array}{l}\text { Controle } \\
\text { Negativo } 1\end{array}$ & 14600 & 22 & 72 & 6 & 0 & 0 & 3212 & 10512 & 876 & 0 & 0 & Morfologia celular normal \\
\hline & $10^{1}-1$ & 10500 & 24 & 70 & 4 & 0 & 2 & 2520 & 7350 & 420 & 0 & 210 & Morfologia celular normal \\
\hline & $10^{2}-1$ & 13600 & 18 & 78 & 2 & 2 & 0 & 2448 & 10608 & 272 & 272 & 0 & Linfócitos reativos + \\
\hline & $10^{2}-2$ & 8500 & 12 & 74 & 12 & 2 & 0 & 1020 & 6290 & 1020 & 170 & 0 & Linfócitos reativos (+) \\
\hline & $10^{3}-1$ & 9500 & 22 & 69 & 8 & 1 & 0 & 2090 & 6555 & 760 & 95 & 0 & Linfócitos reativos (+) \\
\hline & $10^{3}-2$ & 5500 & 30 & 60 & 6 & 4 & 0 & 1650 & 3300 & 330 & 220 & 0 & Morfologia celular normal \\
\hline & $10^{4}-1$ & 7500 & 28 & 70 & 2 & 0 & 0 & 2100 & 5250 & 150 & 0 & 0 & Linfócitos reativos (+) \\
\hline \multirow{4}{*}{$\begin{array}{l}\mathcal{2} \\
1 \\
\stackrel{2}{2}\end{array}$} & $10^{1} 1$ & 13100 & 32 & 48 & 20 & 0 & 0 & 4192 & 6288 & 2620 & 0 & 0 & $\begin{array}{c}\text { Eritrócitos policromáticos }+ \text {, anisocitose }++ \text {. } \\
\text { Presença de células degeneradas. }\end{array}$ \\
\hline & $10^{12}$ & 10000 & 20 & 74 & 6 & 0 & 0 & 2000 & 7400 & 600 & 0 & 0 & $\begin{array}{c}\text { Eritrócitos policromáticos +, anisocitose ++. } \\
\text { Presença de células degeneradas. }\end{array}$ \\
\hline & $10^{2} 1$ & 6500 & 28 & 60 & 8 & 4 & 0 & 1820 & 3900 & 520 & 260 & 0 & $\begin{array}{c}\text { Eritrócitos policromáticos +, anisocitose ++. } \\
\text { Presença de células degeneradas. }\end{array}$ \\
\hline & $10^{3} 2$ & 4500 & 28 & 56 & 16 & 0 & 0 & 1260 & 2520 & 720 & 0 & 0 & $\begin{array}{c}\text { Eritrócitos policromáticos +, anisocitose ++. } \\
\text { Presença de células degeneradas. }\end{array}$ \\
\hline \multirow{7}{*}{ 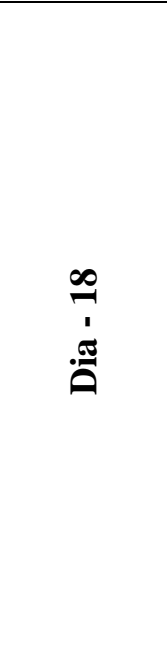 } & $\begin{array}{l}\text { Controle } \\
\text { Negativo } 1\end{array}$ & 10500 & 42 & 52 & 5 & 1 & 0 & 4410 & 5460 & 525 & 105 & 0 & Eritrócitos policromáticos $(+)$ \\
\hline & $10^{1} 1$ & 6000 & 30 & 66 & 4 & 0 & 0 & 1800 & 3960 & 240 & 0 & 0 & $\begin{array}{c}\text { Eritrócitos policromáticos }(+) \text {, anisocitose }+ \text {. } \\
\text { Presença de células degeneradas. }\end{array}$ \\
\hline & $10^{2} 1$ & 12600 & 28 & 66 & 4 & 0 & 2 & 3528 & 8316 & 504 & 0 & 252 & $\begin{array}{c}\text { Eritrócitos policromáticos (+), anisocitose +. } \\
\text { Linfócitos reativos }+ \\
\text { Presença de células degeneradas. }\end{array}$ \\
\hline & $10^{2} 2$ & 11600 & 20 & 76 & 4 & 0 & 0 & 2320 & 8816 & 464 & 0 & 0 & $\begin{array}{c}\text { Eritrócitos policromáticos }(+) \text {, anisocitose }+ \text {. } \\
\text { Presença de células degeneradas. }\end{array}$ \\
\hline & $10^{3} 2$ & 7000 & 10 & 88 & 2 & 0 & 0 & 700 & 6160 & 140 & 0 & 0 & Eritrócitos policromáticos (+), anisocitose + . \\
\hline & $10^{4} 1$ & 8000 & 26 & 66 & 8 & 0 & 0 & 2080 & 5280 & 640 & 0 & 0 & Eritrócitos policromáticos $(+)$, anisocitose + . \\
\hline & $10^{4} 2$ & 13000 & 16 & 78 & 6 & 0 & 0 & 2080 & 10140 & 780 & 0 & 0 & $\begin{array}{c}\text { Eritrócitos policromáticos (+), anisocitose }+ \text {. } \\
\text { Presença de células degeneradas. }\end{array}$ \\
\hline
\end{tabular}


Tabela 9 - Resultados de leucograma (conclusão).

\begin{tabular}{|c|c|c|c|c|c|c|c|c|c|c|c|c|c|}
\hline \multirow{2}{*}{$\begin{array}{l}\text { Dia Pós- } \\
\text { Infecção }\end{array}$} & \multirow[b]{2}{*}{ Animal } & \multirow{2}{*}{$\begin{array}{l}\text { Leucócito } \\
\text { s }(/ \mu L)\end{array}$} & \multicolumn{5}{|c|}{ Leucócitos Relativos (\%) } & \multicolumn{5}{|c|}{ Leucócitos Absolutos $(/ \mu \mathrm{L})$} & \multirow[b]{2}{*}{ OBS } \\
\hline & & & $\begin{array}{l}\text { Neutr } \\
\text { ófilos }\end{array}$ & $\begin{array}{l}\text { Linfóc } \\
\text { itos }\end{array}$ & $\begin{array}{l}\text { Monóc } \\
\text { itos }\end{array}$ & $\begin{array}{c}\text { Eosinó } \\
\text { filos }\end{array}$ & $\begin{array}{c}\text { Basófil } \\
\text { os }\end{array}$ & $\begin{array}{l}\text { Neutr } \\
\text { ófilos }\end{array}$ & $\begin{array}{c}\text { Linfóc } \\
\text { itos }\end{array}$ & $\begin{array}{l}\text { Monóc } \\
\text { itos }\end{array}$ & $\begin{array}{c}\text { Eosinó } \\
\text { filos }\end{array}$ & $\begin{array}{c}\text { Basóf } \\
\text { ilos }\end{array}$ & \\
\hline \multirow{7}{*}{ 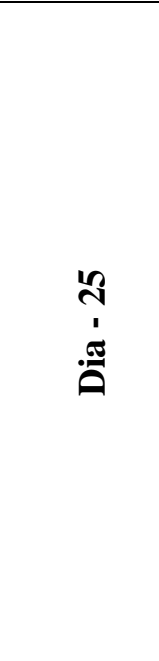 } & $\begin{array}{l}\text { Controle } \\
\text { Negativo } 1\end{array}$ & 7000 & 16 & 80 & 4 & 0 & 0 & 1120 & 5600 & 280 & 0 & 0 & $\begin{array}{l}\text { Eritrócitos policromáticos }(+) \text {, presença de } \\
\text { células degeneradas. }\end{array}$ \\
\hline & $\begin{array}{l}\text { Controle } \\
\text { Negativo } 2\end{array}$ & 6500 & 20 & 72 & 8 & 0 & 0 & 1300 & 4680 & 520 & 0 & 0 & $\begin{array}{l}\text { Eritrócitos policromáticos }(+) \text {, presença de } \\
\text { células degeneradas. }\end{array}$ \\
\hline & $10^{1} 1$ & 7000 & 38 & 52 & 8 & 2 & 0 & 2660 & 3640 & 560 & 140 & 0 & $\begin{array}{l}\text { Eritrócitos policromáticos (+), anisocitose +. } \\
\text { Presença de células degeneradas. }\end{array}$ \\
\hline & $10^{1} 2$ & 3000 & 16 & 80 & 4 & 0 & 0 & 480 & 2400 & 120 & 0 & 0 & $\begin{array}{l}\text { Eritrócitos policromáticos }(+) \text {, anisocitose }(+) \text {. } \\
\text { Presença de células degeneradas. }\end{array}$ \\
\hline & $10^{3} 2$ & 4500 & 24 & 70 & 4 & 2 & 0 & 1080 & 3150 & 180 & 90 & 0 & $\begin{array}{l}\text { Linfócitos reativos (+). } \\
\text { Presença de células degeneradas. }\end{array}$ \\
\hline & $10^{4} 1$ & 6500 & 44 & 52 & 4 & 0 & 0 & 2860 & 3380 & 260 & 0 & 0 & $\begin{array}{c}\text { Eritrócitos policromáticos }(+) \text {, anisocitose }(+) \text {. } \\
\text { Presença de células degeneradas. }\end{array}$ \\
\hline & $10^{4} 2$ & 7000 & 30 & 66 & 4 & 0 & 0 & 2100 & 4620 & 280 & 0 & 0 & $\begin{array}{l}\text { Eritrócitos policromáticos (+), anisocitose ++ } \\
\text { Presença de células degeneradas. }\end{array}$ \\
\hline \multirow{7}{*}{ 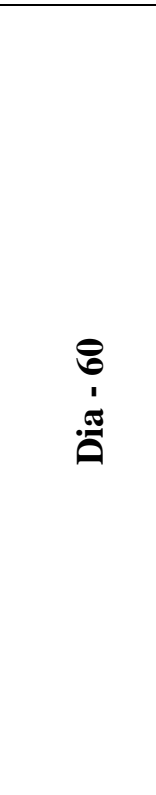 } & $\begin{array}{l}\text { Controle } \\
\text { Negativo } 1\end{array}$ & 10000 & 12 & 88 & 0 & 0 & 0 & 1200 & 8800 & 0 & 0 & 0 & $\begin{array}{l}\text { Eritrócitos policromáticos (+), presença de } \\
\text { células degeneradas. }\end{array}$ \\
\hline & $10^{1} 1$ & 5000 & 18 & 76 & 6 & 0 & 0 & 900 & 3800 & 300 & 0 & 0 & $\begin{array}{l}\text { Eritrócitos policromáticos }(+) \text {, anisocitose }(+) \text {. } \\
\text { Presença de células degeneradas. }\end{array}$ \\
\hline & $10^{1} 2$ & 6000 & 30 & 58 & 12 & 0 & 0 & 1800 & 3480 & 720 & 0 & 0 & $\begin{array}{l}\text { Linfócitos reativos }(+) \text {. } \\
\text { Presenca de células degeneradas e fibrina. }\end{array}$ \\
\hline & $10^{2} 2$ & 7000 & 28 & 65 & 7 & 0 & 0 & 1960 & 4550 & 490 & 0 & 0 & $\begin{array}{c}\text { Eritrócitos policromáticos }(+) \text {. } \\
\text { Linfócitos reativos }+ \\
\text { Presença de células degeneradas. }\end{array}$ \\
\hline & $10^{3} 2$ & 15600 & 24 & 68 & 8 & 0 & 0 & 3744 & 10608 & 1248 & 0 & 0 & $\begin{array}{c}\text { Eritrócitos policromáticos (+), anisocitose +. } \\
\text { Linfócitos reativos + } \\
\text { Presença de células degeneradas. }\end{array}$ \\
\hline & $10^{4} 1$ & 14000 & 22 & 76 & 2 & 0 & 0 & 3080 & 10640 & 280 & 0 & 0 & $\begin{array}{c}\text { Eritrócitos policromáticos }(+) \text {, anisocitose }++ \text {. } \\
\text { Linfócitos reativos }(+) \\
\text { Presença de células degeneradas. }\end{array}$ \\
\hline & $10^{4} 2$ & 5000 & 20 & 80 & 0 & 0 & 0 & 1000 & 4000 & 0 & 0 & 0 & $\begin{array}{l}\text { Eritrócitos policromáticos }(+) \text {, anisocitose }+ \text {. } \\
\text { Presença de células degeneradas. }\end{array}$ \\
\hline
\end{tabular}

Observações: escala de cruzes: (+), +, ++, +++.

Fonte: Própria autoria. 
Tabela 10 - Resultados de bioquímica plasmática (continua).

\begin{tabular}{|c|c|c|c|c|}
\hline $\begin{array}{l}\text { Dia Pós- } \\
\text { Infecção }\end{array}$ & Amostra & ALT (U/L) & AST (U/L) & OBS \\
\hline \multirow{10}{*}{ 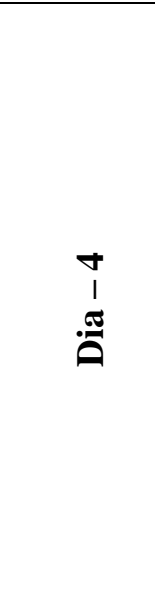 } & Controle Negativo 1 & 240 & 470 & Ndn \\
\hline & Controle Negativo 2 & 40 & 292 & - \\
\hline & $10^{1} 1$ & 20 & 272 & Hemólise ++ \\
\hline & $10^{1} 2$ & Sem leitura* & Sem leitura* & Hemólise ++ \\
\hline & $10^{2} 1$ & 20 & 220 & Hemólise + \\
\hline & $10^{2} 2$ & 30 & 366 & Hemólise + \\
\hline & $10^{3} 1$ & 30 & $\begin{array}{c}\text { Amostra } \\
\text { insuficiente }\end{array}$ & - \\
\hline & $10^{3} 2$ & 40 & Sem leitura* & Hemólise +++ \\
\hline & $10^{4} 1$ & 20 & 94 & Hemólise ++ \\
\hline & $10^{4} 2$ & 30 & 230 & Hemólise ++ \\
\hline \multirow{10}{*}{ 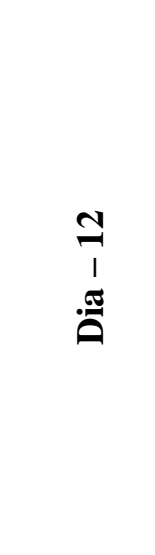 } & Controle Negativo 1 & 54 & 196 & $\mathrm{Ndn}$ \\
\hline & Controle Negativo 2 & 167 & 694 & Ndn \\
\hline & $10^{1} 1$ & 138 & 147 & Ndn \\
\hline & $10^{1} 2$ & 10 & 45 & Hemólise (+) \\
\hline & $10^{2} 1$ & 23 & 175 & Hemólise ++ \\
\hline & $10^{2} 2$ & 43 & 471 & Ndn \\
\hline & $10^{3} 1$ & 20 & 113 & Hemólise +++ \\
\hline & $10^{32}$ & 18 & 189 & Ndn \\
\hline & $10^{4} 1$ & 37 & 89 & Ndn \\
\hline & $10^{4} 2$ & 31 & 309 & Ndn \\
\hline \multirow{10}{*}{$\begin{array}{c}\stackrel{\infty}{a} \\
1 \\
\stackrel{\sigma}{\theta}\end{array}$} & Controle Negativo 1 & 74 & 184 & Ndn \\
\hline & Controle Negativo 2 & 5 & 161 & Ndn \\
\hline & $10^{1} 1$ & 26 & 174 & Hemólise +++ \\
\hline & $10^{1} 2$ & 80 & $427 *$ & Ndn \\
\hline & $10^{2} 1$ & 4 & 61 & Ndn \\
\hline & $10^{2} 2$ & 21 & 213 & Hemólise +++ \\
\hline & $10^{3} 1$ & 225 & 229 & Ndn \\
\hline & $10^{3} 2$ & 10 & 130 & Ndn \\
\hline & $10^{4} 1$ & 13 & 83 & Ndn \\
\hline & $10^{4} 2$ & 154 & 149 & Hemólise (+) \\
\hline
\end{tabular}


Tabela 10 - Resultados de bioquímica plasmática (conclusão).

\begin{tabular}{|c|c|c|c|c|}
\hline $\begin{array}{l}\text { Dia Pós- } \\
\text { Infecção }\end{array}$ & Amostra & $\operatorname{ALT}(\mathbf{U} / \mathbf{L})$ & AST (U/L) & OBS \\
\hline \multirow{10}{*}{$\begin{array}{l}\text { 노 } \\
1 \\
\stackrel{\pi}{0} \\
\end{array}$} & Controle Negativo 1 & 14 & 98 & Hemólise $(+)$ \\
\hline & Controle Negativo 2 & 8 & 78 & Ndn \\
\hline & $10^{1} 1$ & 23 & 362 & Ndn \\
\hline & $10^{1} 2$ & 37 & 174 & Hemólise ++ \\
\hline & $10^{2} 1$ & 50 & 185 & Ndn \\
\hline & $10^{2} 2$ & ** & ** & ** \\
\hline & $10^{3} 1$ & 14 & 292 & Hemólise ++ \\
\hline & $10^{3} 2$ & 15 & 330 & Ndn \\
\hline & $10^{4} 1$ & 8 & 126 & Ndn \\
\hline & $10^{4} 2$ & 18 & 77 & Hemólise ++ \\
\hline \multirow{10}{*}{$\begin{array}{l}8 \\
1 \\
0 \\
0\end{array}$} & Controle Negativo 1 & 16 & 133 & Hemólise + \\
\hline & Controle Negativo 2 & 9 & 170 & Ndn \\
\hline & $10^{1} 1$ & 6 & 91 & Ndn \\
\hline & $10^{1} 2$ & 13 & 192 & Ndn \\
\hline & $10^{2} 1$ & 17 & 332 & Ndn \\
\hline & $10^{2} 2$ & 6 & 30 & Ndn \\
\hline & $10^{3} 1$ & 22 & 399 & Ndn \\
\hline & $10^{3} 2$ & 8 & 111 & Ndn \\
\hline & $10^{4} 1$ & 7 & 115 & Ndn \\
\hline & $10^{4} 2$ & 5 & 47 & Ndn \\
\hline
\end{tabular}

Observação: Escala de cruzes: $(+),+,++,+++$.

* Amostra insuficiente para repetição.

** Não realizado.

Ndn: nada digno de nota.

Fonte: Própria autoria. 
Tabela 11 - Resultados de índices somáticos (continua).

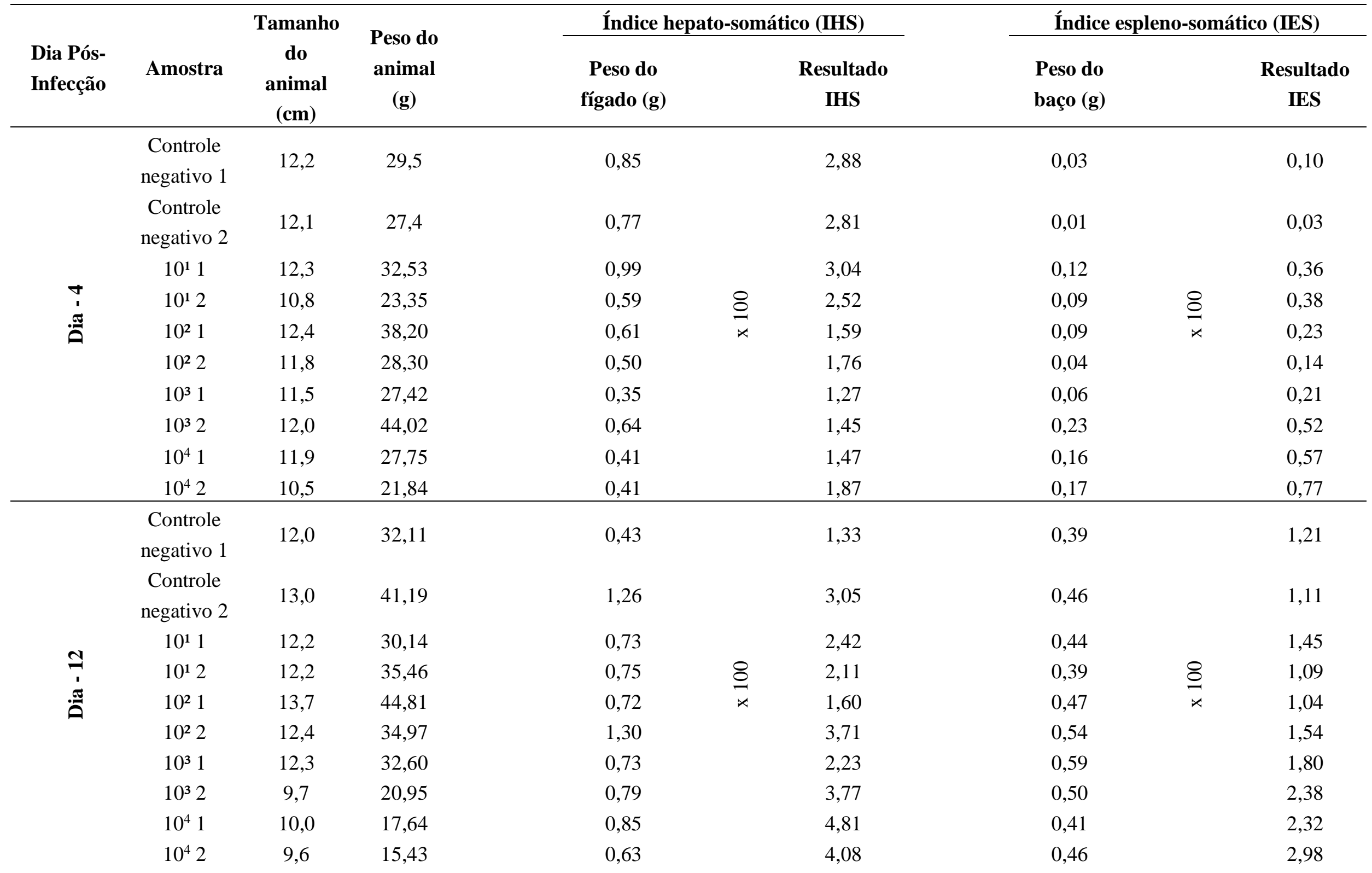


Tabela 11 - Resultados de índices somáticos (continuação).

\begin{tabular}{|c|c|c|c|c|c|c|c|c|c|}
\hline \multirow[b]{2}{*}{$\begin{array}{l}\text { Dia Pós- } \\
\text { Infecção }\end{array}$} & \multirow[b]{2}{*}{ Amostra } & \multirow{2}{*}{$\begin{array}{l}\text { Tamanho } \\
\text { do } \\
\text { animal } \\
\text { (cm) }\end{array}$} & \multirow{2}{*}{$\begin{array}{c}\text { Peso do } \\
\text { animal } \\
\text { (g) }\end{array}$} & \multicolumn{3}{|c|}{ Índice hepato-somático (IHS) } & \multicolumn{3}{|c|}{ Índice espleno-somático (IES) } \\
\hline & & & & $\begin{array}{c}\text { Peso do } \\
\text { fígado (g) }\end{array}$ & & $\begin{array}{l}\text { Resultado } \\
\text { IHS }\end{array}$ & $\begin{array}{l}\text { Peso do } \\
\text { baço (g) }\end{array}$ & & $\begin{array}{l}\text { Resultado } \\
\text { IES }\end{array}$ \\
\hline \multirow{10}{*}{ 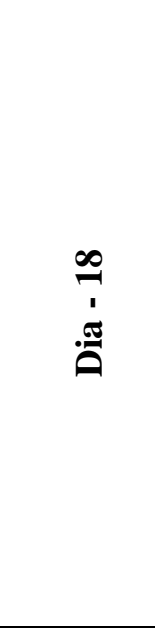 } & & & & 0,91 & \multirow{10}{*}{$\underset{x}{\stackrel{8}{1}}$} & 2,53 & 0,20 & \multirow{10}{*}{$\underset{x}{\stackrel{8}{8}}$} & 0,55 \\
\hline & $\begin{array}{c}\text { Controle } \\
\text { negativo } 2\end{array}$ & 13,9 & 36,65 & 0,93 & & 2,53 & 0,22 & & 0,60 \\
\hline & $10^{1} 1$ & 13,3 & 45,47 & 0,54 & & 1,18 & 0,21 & & 0,46 \\
\hline & $10^{12}$ & 12,5 & 33,24 & 0,36 & & 1,08 & 0,11 & & 0,33 \\
\hline & $10^{2} 1$ & 12,0 & 32,11 & 0,91 & & 2,83 & 0,11 & & 0,34 \\
\hline & $10^{2} 2$ & 14,8 & 56,88 & 0,75 & & 1,31 & 0,16 & & 0,28 \\
\hline & $10^{3} 1$ & 12,5 & 34,53 & 0,73 & & 2,11 & 0,10 & & 0,28 \\
\hline & $10^{3} 2$ & 11,2 & 28,59 & 0,58 & & 2,02 & 0,17 & & 0,59 \\
\hline & $10^{4} 1$ & 12,7 & 33,76 & 0,74 & & 2,19 & 0,09 & & 0,26 \\
\hline & $10^{4} 2$ & 13,4 & 36,96 & 0,69 & & 1,86 & 0,28 & & 0,75 \\
\hline \multirow{10}{*}{ 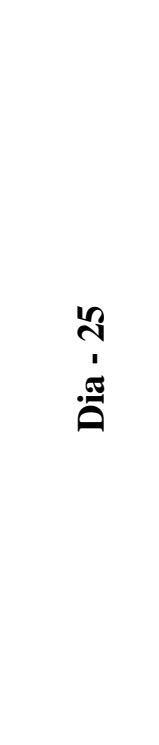 } & $\begin{array}{c}\text { Controle } \\
\text { negativo } 1\end{array}$ & 13,4 & 42,5 & 1,20 & \multirow{10}{*}{ 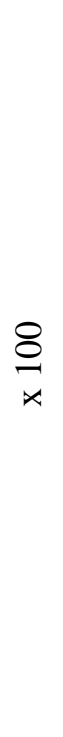 } & 2,82 & 0,30 & \multirow{10}{*}{$\underset{x}{\stackrel{8}{8}}$} & 0,70 \\
\hline & $\begin{array}{c}\text { Controle } \\
\text { negativo } 2\end{array}$ & 10,5 & 20,7 & 0,50 & & 2,41 & 0,30 & & 1,44 \\
\hline & $10^{1} 1$ & 11,6 & 29,7 & 0,50 & & 1,68 & 0,30 & & 1,01 \\
\hline & $10^{12}$ & 11,2 & 24,8 & 0,52 & & 2,09 & 0,24 & & 0,96 \\
\hline & $10^{2} 1$ & 10,8 & 22,5 & 0,62 & & 2,75 & 0,33 & & 1,46 \\
\hline & $10^{2} 2$ & -- & -- & -- & & $\begin{array}{c}\text { Peixes } \\
\text { insuficientes }\end{array}$ & -- & & $\begin{array}{c}\text { Peixes } \\
\text { insuficientes }\end{array}$ \\
\hline & $10^{3} 1$ & 14,3 & 44,7 & 0,72 & & 1,61 & 0,21 & & 0,46 \\
\hline & $10^{3} 2$ & 11,4 & 26,9 & 0,76 & & 2,82 & 0,34 & & 1,26 \\
\hline & $10^{4} 1$ & 11,4 & 26,3 & 0,52 & & 1,97 & 0,20 & & 0,76 \\
\hline & $10^{4} 2$ & 14,1 & 45,0 & 1,00 & & 2,22 & 0,31 & & 0,68 \\
\hline
\end{tabular}


Tabela 11 - Resultados de índices somáticos (conclusão).

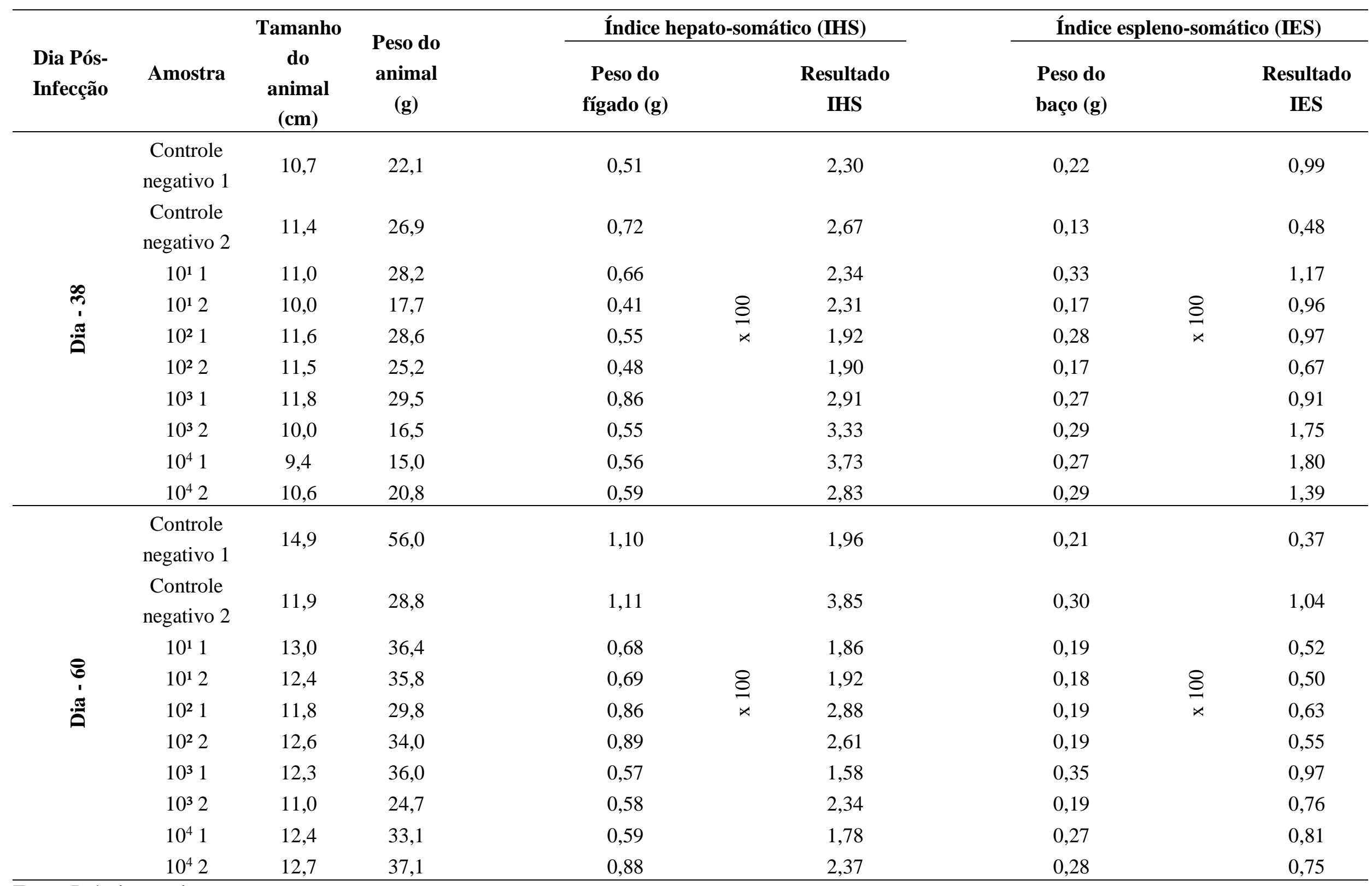

Fonte: Própria autoria. 
Tabela 12 - Resultados para análise estatística com alanina aminotransferase.

\begin{tabular}{|c|c|c|c|c|c|c|c|c|c|c|c|c|c|c|c|}
\hline dias & & & 4 & & & & & & & & & & 18 & & \\
\hline concentração & $\mathbf{0}$ & 1 & 2 & 3 & 4 & $\mathbf{0}$ & 1 & 2 & 3 & 4 & $\mathbf{0}$ & 1 & 2 & 3 & 4 \\
\hline ALT & 140 & 20 & 25 & 35 & 25 & 110,5 & 74 & 33 & 19 & 34 & 39,5 & 53 & 12,5 & 117,5 & 83,5 \\
\hline
\end{tabular}

\begin{tabular}{lcccccccccc}
\hline dias & \multicolumn{1}{c}{$\mathbf{2 5}$} & \multicolumn{1}{c}{$\mathbf{6 0}$} \\
\hline concentração & $\mathbf{0}$ & $\mathbf{1}$ & $\mathbf{2}$ & $\mathbf{3}$ & $\mathbf{4}$ & $\mathbf{0}$ & $\mathbf{1}$ & $\mathbf{2}$ & $\mathbf{3}$ & $\mathbf{4}$ \\
ALT & 11 & 30 & 50 & 14,5 & 13 & 12,5 & 9,5 & 11,5 & 15 & 6 \\
\hline
\end{tabular}

$\frac{\text { SEM }}{40,97546}$

\begin{tabular}{ccc}
\hline \multicolumn{3}{c}{$\boldsymbol{p}$-value } \\
\hline Concentração & Dia & Concentração*Dia \\
0,8733 & 0,0392 & 0,7138 \\
\hline
\end{tabular}

\begin{tabular}{lccccc}
\hline \multicolumn{7}{c}{ Efeito da concentração viral } \\
\hline \multicolumn{7}{c}{ Concentração viral } \\
& $\mathbf{1 0}^{\mathbf{0}}$ & $\mathbf{1 0}^{\mathbf{1}}$ & $\mathbf{1 0}^{\mathbf{2}}$ & $\mathbf{1 0}^{\mathbf{3}}$ & $\mathbf{1 0}^{\mathbf{4}}$ \\
ALT & 62,7 & 37,3 & 26,4 & 40,2 & 32,3 \\
\hline
\end{tabular}

\begin{tabular}{cc}
$\frac{\boldsymbol{p} \text { SEMalue }}{18,41}$ & 0,8733 \\
\hline
\end{tabular}

\section{Efeito do dia}

Dia

$$
\text { Dia } 18
$$

$18 \quad 25$

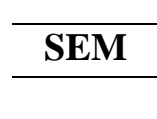

60

ALT $\quad 49^{\text {a }} \quad 54,1^{\text {a }} \quad 61,2^{\text {a }} \quad 23,7^{\text {ab }} \quad 10,9^{\text {b }}$

18,41

$p$-value

*Valores em uma mesma linha, seguidos por letras minúsculas diferentes, diferem entre si ao nível de $5 \%$ de probabilidade.

Fonte: Própria autoria. 
Tabela 13 - Resultados para análise estatística com aspartato aminotransferase.

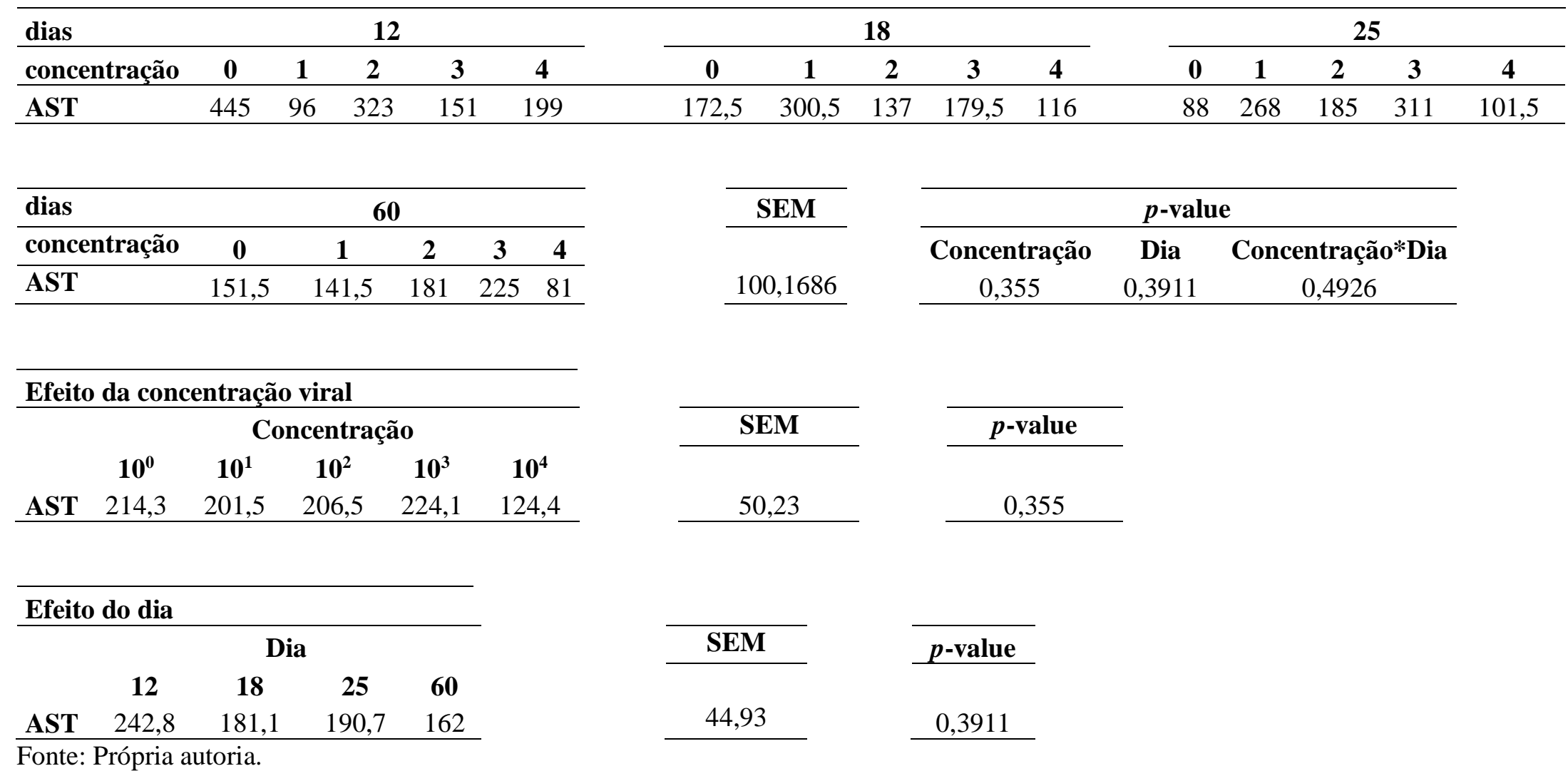


Tabela 14 - Resultados para análise estatística com leucograma (leucócitos, neutrófilos, linfócitos e monócitos).

\begin{tabular}{|c|c|c|c|c|c|c|c|c|c|c|c|c|}
\hline \multirow{2}{*}{$\begin{array}{l}\text { dias } \\
\text { concentração }\end{array}$} & \multicolumn{4}{|c|}{4} & \multicolumn{4}{|c|}{18} & \multicolumn{4}{|c|}{25} \\
\hline & $10^{0}$ & $10^{1}$ & $10^{3}$ & $10^{4}$ & $10^{0}$ & $10^{1}$ & $10^{3}$ & $10^{4}$ & $10^{0}$ & $10^{1}$ & $10^{3}$ & $10^{4}$ \\
\hline Leucócitos & 14600 & 10500 & 7500 & 7500 & 10500 & 6000 & 7000 & 10500 & 6750 & 5000 & 4500 & 6750 \\
\hline Neutrófilos & 3212 & 2520 & 187 & 2100 & 4410 & 1800 & 700 & 2080 & 1210 & 2660 & 1080 & 2480 \\
\hline Linfócitos & 10512 & 7350 & 4927,5 & 5250 & 5460 & 3960 & 6160 & 7710 & 5140 & 3020 & 3150 & 4000 \\
\hline Monócitos & 876 & 420 & 545 & 150 & 525 & 240 & 140 & 710 & 400 & 340 & 180 & 270 \\
\hline dias & \multicolumn{4}{|c|}{60} & & & \multicolumn{4}{|c|}{$p$-value } & & \\
\hline concentração & $10^{0}$ & $10^{1}$ & $10^{3}$ & $10^{4}$ & \multicolumn{2}{|l|}{ SEM } & Concentração & Dia & \multicolumn{4}{|c|}{ Concentração*Dia } \\
\hline Leucócitos & 10000 & 5500 & 15600 & 9500 & 2752,135 & & 0,4144 & 0,18 & \multicolumn{2}{|l|}{0,7301} & & \\
\hline Neutrófilos & 1200 & 1350 & 3744 & 2040 & 626,2838 & & 0,5687 & 0,6119 & \multicolumn{2}{|l|}{0,1538} & & \\
\hline Linfócitos & 8800 & 3640 & 10608 & 7320 & 2114,251 & & 0,2962 & 0,1034 & \multicolumn{2}{|l|}{0,6288} & & \\
\hline Monócitos & 0 & 510 & 1248 & 140 & 186,5063 & & 0,709 & 0,6695 & 0,1046 & & & \\
\hline
\end{tabular}

\section{Efeito da concentração viral}

\begin{tabular}{lcccccr}
\hline & \multicolumn{7}{c}{ Concentração } \\
\cline { 2 - 5 } Leucócitos & $\mathbf{1 0}^{\mathbf{0}}$ & $\mathbf{1 0}^{\mathbf{1}}$ & $\mathbf{1 0}^{\mathbf{3}}$ & $\mathbf{1 0}^{\mathbf{4}}$ & SEM & $\boldsymbol{p}$-value \\
Neutrófilos & 10463 & 6750 & 8650 & 8562,5 & 1053,55 & 0,4144 \\
Linfócitos & 2508 & 2082,5 & 1848,5 & 2175 & 316,3225 & 0,5687 \\
Monócitos & 4478 & 4492,5 & 6211,38 & 6070 & 1069,248 & 0,2962 \\
\hline
\end{tabular}

\begin{tabular}{lcccccr}
\hline Efeito do dia & \multicolumn{7}{c}{ Dia } \\
\cline { 2 - 7 } & $\mathbf{4}$ & $\mathbf{1 8}$ & $\mathbf{2 5}$ & $\mathbf{6 0}$ & SEM & $\boldsymbol{p}$-value \\
\cline { 2 - 7 } Leucócitos & 10025 & 8500 & 5750 & 10150 & 1391,848 & 0,18 \\
Neutrófilos & 2425,5 & 2247,5 & 1857,5 & 2083,5 & 316,855 & 0,6119 \\
Linfócitos & $7009,88^{a}$ & $5822,5^{a b}$ & $3827,5^{\mathrm{b}}$ & $7592^{\mathrm{a}}$ & 1069,248 & 0,1034 \\
Monócitos & 497,75 & 403,75 & 297,5 & 474,5 & 99,35735 & 0,6695 \\
\hline
\end{tabular}

*Valores em uma mesma linha, seguidos por letras minúsculas diferentes, diferem entre si ao nível de 5 \% de probabilidade. Fonte: Própria autoria. 
Tabela 15 - Resultados para análise estatística com leucograma (eosinófilos e basófilos).

\begin{tabular}{|c|c|c|c|c|c|c|}
\hline \multicolumn{7}{|c|}{ Efeito da concentração viral } \\
\hline & \multicolumn{4}{|c|}{ Concentração } & \multirow[b]{2}{*}{ SEM } & \multirow[b]{2}{*}{$p$-value } \\
\hline & $10^{0}$ & $10^{1}$ & $10^{3}$ & $10^{4}$ & & \\
\hline $\mathbf{n}$ & 5 & 6 & 5 & 7 & & \\
\hline Eosinófilos & 11,8 & 11,58333 & 16,2 & 9,5 & 10,12248 & 0,1354 \\
\hline \multicolumn{7}{|c|}{ Efeito da concentração viral } \\
\hline & \multicolumn{3}{|c|}{ Concentração } & & & \\
\hline & $10^{0}$ & $10^{1}$ & $10^{3}$ & $10^{4}$ & SEM & $p$-value \\
\hline $\mathbf{n}$ & 5 & 6 & 5 & 7 & & \\
\hline Basófilos & 11,5 & 13,41667 & 11,5 & 11,5 & 4,957022 & 0,418 \\
\hline
\end{tabular}

Para estas variáveis, foi utilizado uma estatística não paramétrica, pois não respeitou a normalidade dos resíduos (mesmo transformando os dados). Desta forma, foi utilizado o teste Kruskal-Wallis empregando categorias (com base na quantidade de observações). Analisou-se apenas o efeito da concentração viral (sem considerar dias), devido ao número de repetições por tratamento. 
Tabela 16 - Resultados para análise estatística com eritrograma (continua).

\begin{tabular}{|c|c|c|c|c|c|c|c|c|c|}
\hline \multirow{2}{*}{$\begin{array}{l}\text { dias } \\
\text { concentração }\end{array}$} & \multicolumn{4}{|c|}{4} & & \multicolumn{4}{|c|}{18} \\
\hline & $10^{0}$ & $10^{1}$ & $10^{3}$ & $10^{4}$ & & $10^{0}$ & $10^{1}$ & $10^{3}$ & $10^{4}$ \\
\hline Eritrócitos & $964800 \quad 9$ & 924600 & 1924575 & 1085400 & & 934650 & 944700 & 1567800 & 1266300 \\
\hline Hemoglobina & 5,6 & 5,8 & 4,45 & 4 & & 5,4 & 6,2 & 6,7 & 5,85 \\
\hline Hematócrito & 29 & 27 & 23 & 21 & & 25 & 23 & 29 & 27,5 \\
\hline VCM & 300,6 & 292 & 121,3 & 193,5 & & 267,5 & 243,5 & 185 & 218,15 \\
\hline HCM & 58 & 62,7 & 22,95 & 36,9 & & 57,8 & 65,6 & 42,7 & 46,45 \\
\hline СНСM & 19,3 & 21,5 & 19,1 & 19 & & 21,6 & 27 & 23,1 & 21,3 \\
\hline Proteína & 3 & 3 & 3 & 2,2 & & 4,4 & 5 & 4 & 4,4 \\
\hline \multirow{2}{*}{\multicolumn{2}{|c|}{$\begin{array}{l}\text { dias } \\
\text { concentração }\end{array}$}} & \multicolumn{4}{|c|}{60} & \multirow{2}{*}{\multicolumn{3}{|c|}{ SEM }} & \\
\hline & & $10^{0}$ & $10^{1}$ & $10^{3}$ & $10^{4}$ & & & & Concentr \\
\hline Eritrócitos & & 1306500 & 969825 & 1859250 & 1346700 & \multicolumn{3}{|c|}{396524,1} & 0,164 \\
\hline Hemoglobina & & 5,5 & 4,45 & 4,3 & 3,9 & \multicolumn{3}{|c|}{0,891881} & 0,6532 \\
\hline Hematócrito & & 27 & 19,5 & 18 & 17,5 & \multicolumn{3}{|c|}{4,643738} & 0,5838 \\
\hline VCM & & 206,7 & 207,7 & 96,8 & 130,15 & \multicolumn{3}{|c|}{23,65736} & 0,0013 \\
\hline HCM & & 42,1 & 47,5 & 23,1 & 29 & \multicolumn{3}{|c|}{6,352413} & 0,002 \\
\hline CHCM & & 20,4 & 22,85 & 23,9 & 22,15 & \multicolumn{3}{|c|}{2,439588} & 0,470 \\
\hline Proteína & & 4,2 & 3,9 & 3,8 & 3,9 & \multicolumn{3}{|c|}{0,584688} & 0,7827 \\
\hline \multicolumn{10}{|c|}{ Efeito da concentração viral } \\
\hline \multicolumn{6}{|c|}{ Concentração } & \multirow{2}{*}{\multicolumn{3}{|c|}{ SEM }} & \\
\hline & $10^{0}$ & & $10^{1}$ & $10^{3}$ & $10^{4}$ & & & & $p$-value \\
\hline Eritrócitos & 1153238 & 11 & 25600 & 1800206 & 1454738 & \multicolumn{3}{|c|}{200535,8} & 0,1649 \\
\hline Hemoglobina & 5,4875 & & 3625 & 5,1625 & 4,75 & \multicolumn{3}{|c|}{0,45105} & 0,6532 \\
\hline Hematócrito & 26,375 & & 2,875 & 23,5 & 21,875 & \multicolumn{3}{|c|}{2,3002} & 0,5838 \\
\hline VCM & $238,59^{a}$ & & $8,49^{\text {a }}$ & $132,03^{b}$ & $159,53^{b}$ & \multicolumn{3}{|c|}{11,71828} & 0,0013 \\
\hline HCM & 49,5125 & 54, & $7125^{a}$ & $28,9625^{b}$ & $34,0875^{b}$ & \multicolumn{3}{|c|}{3,146575} & 0,002 \\
\hline CHCM & 20,9 & & 3,725 & 21,95 & 21,8375 & \multicolumn{3}{|c|}{ 1,2084 } & 0,4709 \\
\hline Proteína & 3,975 & &, 825 & 3,7 & 3,575 & \multicolumn{3}{|c|}{0,2896} & 0,7827 \\
\hline
\end{tabular}


Tabela 16 - Resultados para análise estatística com eritrograma (conclusão).

\begin{tabular}{|c|c|c|c|c|c|c|}
\hline \multicolumn{7}{|l|}{ Efeito do dia } \\
\hline & \multicolumn{4}{|c|}{ Dia } & \multirow[b]{2}{*}{ SEM } & \multirow[b]{2}{*}{$p$-value } \\
\hline & 4 & 18 & 25 & 60 & & \\
\hline Eritrócitos & 1224844 & 1178363 & 1760006 & 13700569 & 200535,8 & 0,2143 \\
\hline Hemoglobina & 4,9625 & 6,0375 & 5,225 & 4,5375 & 0,45105 & 0,2272 \\
\hline Hematócrito & 25 & 26,125 & 23 & 20,5 & 2,3002 & 0,4039 \\
\hline VCM & $226,85^{a}$ & $228,54^{\text {a }}$ & 132,9 b & $160,34^{b}$ & 11,71828 & 0,0012 \\
\hline HCM & 45,1375 ab & $53,1375^{a}$ & $33,575^{c}$ & 35,425 bc & 3,146575 & 0,0105 \\
\hline СНСM & 19,725 & 23,25 & 23,1125 & 22,325 & 1,2084 & 0,252 \\
\hline Proteína & $2,8^{\mathrm{b}}$ & $4,45^{\mathrm{a}}$ & $3,875^{\text {a }}$ & $3,95^{\text {a }}$ & 0,2896 & 0,0344 \\
\hline
\end{tabular}

Proteína $\quad 2,8^{\mathrm{b}} \quad 4,45^{\mathrm{a}} \quad 3,875^{\mathrm{a}} \quad 3,95^{\mathrm{a}}$

*Valores em uma mesma linha, seguidos por letras minúsculas diferentes, diferem entre si ao nível de 5 \% de probabilidade.

Fonte: Própria autoria. 
Tabela 17 - Resultados para análise estatística com índices somáticos (continua).

\begin{tabular}{|c|c|c|c|c|c|c|c|c|c|c|c|c|c|c|c|c|c|c|c|c|}
\hline \multirow{2}{*}{$\begin{array}{l}\text { dias } \\
\text { Concentração }\end{array}$} & \multicolumn{5}{|c|}{4} & \multicolumn{5}{|c|}{12} & \multicolumn{5}{|c|}{18} & \multicolumn{5}{|c|}{25} \\
\hline & 0 & 1 & 2 & 3 & 4 & 0 & 1 & 2 & 3 & 4 & $\mathbf{0}$ & 1 & 2 & 3 & 4 & $\mathbf{0}$ & 1 & 2 & 3 & 4 \\
\hline Tamanho & 12,15 & 11,55 & 12,1 & 11,75 & 11,2 & 12,5 & 12,2 & 13,05 & 11 & 9,8 & 13,25 & 12,9 & 13,4 & 11,85 & 13,05 & 11,95 & 11,4 & 10,8 & 12,85 & 12,75 \\
\hline Peso & 28,45 & 27,94 & 33,25 & 35,72 & 24,8 & 36,65 & 32,8 & 39,89 & 26,78 & 16,54 & 36,25 & 39,36 & 44,495 & 31,56 & 35,36 & 31,6 & 27,25 & 22,5 & 35,8 & 35,65 \\
\hline Fígado & 0,81 & 0,79 & 0,555 & 0,495 & 0,41 & 0,43 & 0,74 & 0,72 & 0,76 & 0,74 & 0,92 & 0,45 & 0,83 & 0,655 & 0,715 & 0,5 & 0,51 & 0,62 & 0,74 & 0,76 \\
\hline IHS & 2,845 & 2,78 & 1,675 & 1,36 & 1,67 & 3,05 & 2,265 & 3,71 & 3 & 4,445 & 2,53 & 1,13 & 2,07 & 2,065 & 2,025 & 2,615 & 1,885 & 2,75 & 2,215 & 2,095 \\
\hline Baço & 0,02 & 0,105 & 0,065 & 0,145 & 0,165 & 0,425 & 0,415 & 0,505 & 0,545 & 0,435 & 0,21 & 0,16 & 0,135 & 0,135 & 0,185 & 0,3 & 0,27 & 0,33 & 0,275 & 0,255 \\
\hline
\end{tabular}

\begin{tabular}{|c|c|c|c|c|c|c|c|c|c|c|c|c|c|c|}
\hline \multirow{2}{*}{$\begin{array}{l}\text { dias } \\
\text { Concentração }\end{array}$} & \multicolumn{5}{|c|}{38} & \multicolumn{5}{|c|}{60} & \multirow{2}{*}{ SEM } & \multicolumn{3}{|c|}{$p$-value } \\
\hline & $\mathbf{0}$ & 1 & 2 & 3 & 4 & $\mathbf{0}$ & 1 & 2 & 3 & 4 & & Concentração & Dia & Concentração*Dia \\
\hline Tamanho & 11,05 & 10,5 & 11,55 & 10,9 & 10 & 13,4 & 12,7 & 12,2 & 11,65 & 12,55 & 0,78205 & 0,3372 & 0,0043 & 0,5665 \\
\hline Fígado & 0,615 & 0,535 & 0,515 & 0,705 & 0,575 & 1,105 & 0,685 & 0,875 & 0,575 & 0,735 & 0,099491 & 0,4315 & 0,0206 & 0,0123 \\
\hline IHS & 2,485 & 2,325 & 1,91 & 3,12 & 3,28 & 1,96 & 1,89 & 2,745 & 1,96 & 2,075 & 0,325967 & 0,0282 & $<.0001$ & 0,0023 \\
\hline Baço & 0,175 & 0,25 & 0,225 & 0,28 & 0,28 & 0,255 & 0,185 & 0,19 & 0,27 & 0,275 & 0,044425 & 0,2927 & $<.0001$ & 0,4875 \\
\hline IES & 0,735 & 1,065 & 0,82 & 1,33 & 1,595 & 0,705 & 0,51 & 0,59 & 0,865 & 0,78 & 0,20276 & 0,0032 & $<.0001$ & 0,0191 \\
\hline
\end{tabular}

\section{Efeito da concentração viral}

\begin{tabular}{|c|c|c|c|c|c|c|c|c|}
\hline & \multicolumn{5}{|c|}{ Concentração } & \multirow[b]{2}{*}{ SEM } & \multirow[b]{2}{*}{$p$-value } & \\
\hline & $10^{0}$ & $10^{1}$ & $10^{2}$ & $10^{3}$ & $10^{4}$ & & & \\
\hline Tamanho & 12,3833 & 11,875 & 12,1833 & 11,6667 & 11,5583 & 0,32 & 0,337 & \\
\hline Peso & 33,3075 & 31,0658 & 33,1558 & 30,5342 & 27,5567 & 2,457 & 0,469 & \\
\hline Fígado & 0,73 & 0,6183 & 0,6858 & 0,655 & 0,6558 & 0,041 & 0,432 & \\
\hline IHS & 2,5808 & 2,0458 & 2,4767 & 2,2867 & 2,5983 & 0,134 & 0,028 & *se considera a interação. \\
\hline Baço & 0,2308 & 0,2308 & 0,2417 & 0,275 & 0,2658 & 0,018 & 0,293 & \\
\hline IES & 0,7183 & 0,7658 & 0,7758 & 0,9908 & 1,1533 & 0,083 & 0,003 & *se considera a interação. \\
\hline
\end{tabular}


Tabela 17 - Resultados para análise estatística com índices somáticos (continuação).

\section{Efeito do dia}

\begin{tabular}{|c|c|c|c|c|c|c|c|c|c|}
\hline & \multicolumn{6}{|c|}{ Dia } & \multirow[b]{2}{*}{ SEM } & \multirow[b]{2}{*}{$p$-value } & \\
\hline & 4 & 12 & 18 & 25 & 38 & 60 & & & \\
\hline Tamanho & $11,75^{\mathrm{b}}$ & $11,71^{\mathrm{b}}$ & $12,89^{\text {a }}$ & $11,95^{a b}$ & $10,8^{\mathrm{b}}$ & $12,5^{a b}$ & 0,35 & 0,004 & \\
\hline Peso & $30,031^{b}$ & 30,53 ab & $37,403^{a}$ & 30,56 ab & $23,05^{b}$ & 35,17 ab & 2,691 & 0,014 & \\
\hline Fígado & 0,612 & 0,678 & 0,714 & 0,626 & 0,589 & 0,795 & 0,045 & 0,021 & \\
\hline IHS & 2,066 & 3,294 & 1,964 & 2,312 & 2,624 & 2,126 & 0,147 & $<.0001$ & *se considera a interaçã \\
\hline Baço & $0,1^{\mathrm{d}}$ & $0,465^{\mathrm{a}}$ & $0,165^{c}$ & $0,286^{b}$ & $0,242^{b}$ & $0,235^{\mathrm{b}}$ & 0,052 & $<.0001$ & \\
\hline IES & 0,331 & 1,692 & 0,444 & 1,019 & 1,109 & 0,69 & 0,091 & $<.0001$ & nnsidera a interaçã \\
\hline
\end{tabular}

*Valores em uma mesma linha, seguidos por letras minúsculas diferentes, diferem entre si ao nível de $5 \%$ de probabilidade.

\section{Interação}

\begin{tabular}{|c|c|c|c|c|c|c|c|c|c|}
\hline \multirow{3}{*}{$\begin{array}{l}\text { Variáveis } \\
\text { IHS }\end{array}$} & \multirow{3}{*}{$\begin{array}{l}\text { Dia } \\
4\end{array}$} & \multicolumn{8}{|c|}{ Concentração } \\
\hline & & $10^{0}$ & \multicolumn{2}{|c|}{$10^{1}$} & \multicolumn{2}{|c|}{$10^{2}$} & \multicolumn{2}{|c|}{$10^{3}$} & $10^{4}$ \\
\hline & & 2,845 a A & 2,78 & a A & 1,675 & b B & 1,36 & b B & $1,67 \quad \mathrm{bc}$ \\
\hline & 12 & 3,05 b A & 2,265 & $\mathrm{~b} A \mathrm{AB}$ & 3,71 & ab A & 3 & $\mathrm{~b}$ AB & 4,445 a \\
\hline & 18 & 2,53 a A & 1,13 & b B & 2,07 & a B & 2,065 & a B & 2,025 a c \\
\hline & 25 & 2,615 a A & 1,885 & $\mathrm{a} B$ & 2,75 & $\mathrm{a} A B$ & 2,215 & $\mathrm{a} B$ & 2,095 a c \\
\hline & 38 & 2,485 ab A & 2,325 & $\mathrm{~b} A \mathrm{AB}$ & 1,91 & b B & 3,12 & ab A & 3,28 a $\mathrm{B}$ \\
\hline & 60 & 1,96 a A & 1,89 & $\mathrm{aB}$ & 2,745 & a $\mathrm{AB}$ & 1,96 & a B & 2,075 a c \\
\hline
\end{tabular}

*Letras maiúsculas na coluna comparam diferentes dias na mesma concentração; letras minúsculas na mesma linha, comparam diferentes concentrações no mesmo dia. 
Tabela 17 - Resultados para análise estatística com índices somáticos (conclusão).

\begin{tabular}{|c|c|c|c|c|c|c|c|c|c|}
\hline \multicolumn{10}{|l|}{ Interação } \\
\hline \multirow{3}{*}{$\begin{array}{l}\text { Variáveis } \\
\text { IES }\end{array}$} & \multirow{3}{*}{$\begin{array}{l}\text { Dias } \\
4\end{array}$} & \multicolumn{8}{|c|}{ Concentração } \\
\hline & & $10^{0}$ & \multicolumn{2}{|c|}{$10^{1}$} & $10^{2}$ & \multicolumn{2}{|c|}{$10^{3}$} & \multicolumn{2}{|c|}{$10^{4}$} \\
\hline & & 0,065 а в & 0,37 & a B & 0,185 а в & 0,365 & a B & 0,67 & a C \\
\hline & 12 & 1,16 с А & 1,27 & c A & 1,29 с A & 2,09 & b A & 2,65 & a A \\
\hline & 18 & 0,575 ав & 0,395 & a B & 0,31 а в & 0,435 & a B & 0,505 & a C \\
\hline & 25 & 1,07 а $\mathrm{AB}$ & 0,985 & $\mathrm{a} A \mathrm{~B}$ & 1,46 a A & 0,86 & a BC & 0,72 & a C \\
\hline & 38 & 0,735 b АB & 1,065 & ab A & 0,82 b AB & 1,33 & ab B & 1,595 & а в \\
\hline & 60 & 0,705 а АВ & 0,51 & a B & 0,59 а в & 0,865 & a BC & 0,78 & a C \\
\hline
\end{tabular}

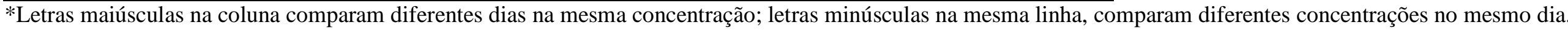
Fonte: Própria autoria. 